MARIANA MARZULLO PEDREIRA

DESENVOLVIMENTO E AVALIAÇÃO DE ESTRATÉGIA DE ENSINO DE GENÉTICA PARA O ENSINO SUPERIOR

BRASÍLIA 


\author{
UNIVERSIDADE DE BRASÍLIA \\ FACULDADE DE CIÊNCIAS DA SAÚDE \\ PROGRAMA DE PÓS-GRADUAÇÃO EM CIÊNCIAS DA SAÚDE
}

MARIANA MARZULLO PEDREIRA

DESENVOLVIMENTO E AVALIAÇÃO DE ESTRATÉGIA DE ENSINO DE GENÉTICA PARA O ENSINO SUPERIOR

Dissertação apresentada como requisito parcial para a obtenção do Título de Mestre em Ciências da Saúde da Universidade de Brasília

Orientador: Silviene Fabiana de Oliveira Co-Orientador: Maria de Nazaré Klautau-Guimarães

BRASÍLIA

2014 
MARIANA MARZULLO PEDREIRA

\title{
DESENVOLVIMENTO E AVALIAÇÃO DE ESTRATÉGIA DE ENSINO DE GENÉTICA PARA O ENSINO SUPERIOR
}

Dissertação apresentada como requisito parcial para a obtenção do título de Mestre em Ciências da Saúde pelo Programa de Pós-Graduação em Ciências da Saúde da Universidade de Brasília

Aprovada em 20 de outubro de 2014

\section{BANCA EXAMINADORA}

Silviene Fabiana de Oliveira (presidente)

Universidade de Brasília

\author{
Celso Teixeira Mendes Júnior \\ Faculdade de Filosofia, Ciências e Letras de Ribeirão Preto (USP)
}

Aline Cabral Braga de Medeiros
Universidade Católica de Brasília

Zulmira Guerrero Marques Lacava

Universidade de Brasília 
Dedico este trabalho à minha amada família.

Pelo amor e apoio, a minha eterna gratidão. 


\section{AGRADECIMENTOS}

À Deus, por estar sempre por perto, mesmo quando estou distante.

Aos meus pais, Joel e Denise, pela paciência, amor e carinho que expressaram por toda a vida a mim e aos meus irmãos, Laura, Bruno e Juliana, que sem os quais não conseguiria percorrer essa etapa da minha vida. Obrigada por sempre torcerem por mim.

Às queridas professoras orientadoras, e sempre chefinhas, Dra. Silviene Fabiana de Oliveira e Dra. Maria de Nazaré Klautau Guimarães, pela oportunidade, orientação, dedicação, incentivo e enriquecedor aprendizado.

Aos professores e funcionários do programa de Pós-Graduação em Ciências da Saúde, do Departamento de Genética e Morfologia e da Universidade de Brasília, pela paciência e atenção despendida.

À CAPES, pelo auxílio financeiro.

À Luna Rufino, pela atenção disponibilizada para desenhar as tirinhas. Elas ficaram lindas graças a você. Muuuuito obrigada!

Às minhas companheiras de luta e amigas de laboratório: Rafaela, Arcanjo, Camila, Sabrina, Tatiana, Marcella e Harumy, e aos dois cromossomos $Y$ do laboratório: Raphael e Arthur, por todos os momentos que passamos juntos, pelas ajudas, pelos incentivos, pelas trocas de experiência, pelas pizzas Hut e festinhas.

Ao pessoal do laboratório ao lado: Cássia, Diogo, Flávia, Gislaine, Niara, Nina, Rosana, Samira e Thaiz, pelos encontros de muito trabalho e brincadeiras, pelos lanchinhos na copa e pelas superproduções de festinhas. Obrigada por me deixarem ser a "plus one" do laboratório de vocês.

Aos meus grandes amigos: Adriano, Alan, Fabíola, Juliana, Mell, Rejane, Talita e Vanessa, por terem sido compreensivos todas as vezes que precisei ficar estudando em vez de me divertir com vocês. Obrigada pela compreensão, carinho e por não terem deixado as ausências afetarem a nossa amizade.

Em especial, à Flavs, vulgo Soares, que dedicou incontáveis horas da sua vida, sono e saúde, para me acompanhar, ajudar, incentivar e apoiar de uma forma incrível, a qual nunca achei que seria possível. Não tenho dúvidas de que não teria concluído sem a sua importantíssima ajuda para o sucesso dessa etapa. Minha eterna gratidão pela sincera amizade. 
"Educação é o que sobrevive quando o que foi aprendido foi esquecido" (Burrhus Frederic Skinner) 


\section{RESUMO}

O Ensino de Genética tornou-se progressivamente um campo essencial da Biologia, devido ao avanço do conhecimento científico da área. O conceito de gene aparece como um dos marcos da história da ciência, entretanto, a partir de 1980, inicia-se a crise com relação a esse conceito devido aos novos conhecimentos acerca do genoma e seu funcionamento. Observa-se grande dificuldade na compreensão do conceito básico por parte de todos os atores envolvidos no processo de ensino-aprendizagem de Genética. O objetivo desse trabalho foi desenvolver e testar um material didático, no formato de tirinhas, que facilite a discussão, avaliação de conhecimentos prévios e reconstrução do conceito, estrutura e função de gene. Inicialmente as tirinhas foram utilizadas para avaliar o conhecimento prévio relacionado ao conceito de gene em turmas de graduação em Enfermagem, Ciências Biológicas e Biotecnologia. Observou-se um conhecimento prévio mais adequado nas turmas de Ciências Biológicas e Biotecnologia em comparação com as turmas de Enfermagem. Esse resultado deve ser decorrente do semestre em que a disciplina é ministrada e da existência de disciplinas prérequisitos nos cursos de Ciências Biológicas e Biotecnologia. Em um segundo momento, as tirinhas foram utilizadas para fomentar a discussão, desconstrução e reconstrução do conceito de gene. Observou-se melhora substancial após a sequência das aulas e dos textos, capacitando os estudantes a reformular respostas mais elaboradas, com o acréscimo de diversos fenômenos que reforçam a afirmação da ausência de correlação 1:1:1 entre gene, sequência de DNA e produto gênico. $O$ conceito molecular clássico de gene foi o conceito mais aceito após a reconstrução, indicando que a sequência didática apresentada permitiu que os estudantes aprimorassem o conceito pré-existente, além de sedimentar uma concepção informacional de gene. A avaliação do material desenvolvido, as tirinhas, foi considerada como um método inovador e criativo pela maioria dos estudantes, e ainda ajudou a compreender e motivar um pensamento crítico na abordagem do tema desenvolvido.

Palavras-chave: conceito de gene; conceito molecular clássico de gene; ensino de Genética; tirinhas. 


\section{ABSTRACT}

Genetics teaching has become an essential studying area in biology, because of its advanced knowledge in the scientific Field. The gene concept appears as one of the frameworks in the history of science, however in the 1980's this concept started to go through a crisis due to new discoveries about genome and its functions It's possible to observe that there are some difficulties in the comprehension of the basic concept in the teaching-learning process of genetics. The aim of this research was to develop and test a didactic material, as comic strip, which facilitates the discussion and evaluates previous knowledge and promotes a reconstruction of gene concepts, structure and function. At first the comic strips were used in under graduation lectures to evaluate the previous knowledge related to the concepts of gene in nurse, biotechnology and biology courses. It was possible to observe a previous knowledge in biology and biotechnology lectures when compared to nurse lectures. This outcome occurs because of the semester that the module is offered in the course and the existence of pre requisite modules. Afterwards the comic strips were used to start discussions, to deconstruct and reconstruct gene concepts. It came to our attention that after the sequence of lectures and texts the students abilities to give more elaborated answers were improved, with the addition of new information that stimulate the affirmation of the absence of correlation 1:1:1 between gene, the sequence of DNA and gene product. The classical molecular concept was the most accepted concept after the reconstruction of knowledge, indicating that the didactical sequence improved the previous knowledge, and also improved the concept of gene. The evaluation of the courseware material, the comic strip was considered an innovative and creative teaching method for most students, and it also facilitated the understanding and motivated a critical thought about the subject studied.

Keywords: gene concept; classical molecular gene concept; genetics teaching; comic strip. 


\section{LISTA DE FIGURAS}

Figura 1 Questionário de questões mistas, aplicado aos estudantes de Ciências Biológicas e Biotecnologia, desenvolvido para verificar se os objetivos das atividades propostas foram atingidos após a sequência didática.

Figura 2 As três tirinhas desenvolvidas, com os seus respectivos enunciados e questionamentos. (a) A tirinha "Palestra" aborda a estrutura do gene e sua relação com a sequência de aminoácido. (b) A tirinha "Genética no bar" prioriza o caráter argumentativo dos estudantes sobre a relação um gene: um proteína. (c) A tirinha "Estudando para a prova" aborda o conceito de gene.

Figura 3 Tirinha 1 desenvolvida por estudantes de Ciências Biológicas e Biotecnologia da Universidade de Brasília, sobre o tema: a crise do conceito de gene.

Figura 4 Tirinha 2 desenvolvida por estudantes de Ciências Biológicas e Biotecnologia da Universidade de Brasília, sobre o tema: a crise do conceito de gene. 49

Figura 5 Tirinha 3 desenvolvida por estudantes de Ciências Biológicas e Biotecnologia da Universidade de Brasília, sobre o tema: a crise do conceito de gene. 50

Figura 6 Tirinha 4 desenvolvida por estudantes de Ciências Biológicas e Biotecnologia da Universidade de Brasília, sobre o tema: a crise do conceito de gene. 50

Figura 7 Tirinha 5 desenvolvida por estudantes de Ciências Biológicas e Biotecnologia da Universidade de Brasília, sobre o tema: a crise do conceito de gene 51

Figura 8 Tirinha 6 desenvolvida por estudantes de Ciências Biológicas e Biotecnologia da Universidade de Brasília, sobre o tema: a crise do conceito de gene 52

Figura 9 Tirinha 7 desenvolvida por estudantes de Ciências Biológicas e Biotecnologia da Universidade de Brasília, sobre o tema: a crise do conceito de gene. 52

Figura 10 Tirinha 8 desenvolvida por estudantes de Ciências Biológicas e Biotecnologia da Universidade de Brasília, sobre o tema: a crise do conceito de gene. 53

Figura 11 Tirinha 9 desenvolvida por estudantes de Ciências Biológicas e Biotecnologia da Universidade de Brasília, sobre o tema: a crise do conceito de gene. 53 
Figura 12 Tirinha 10 desenvolvida por estudantes de Ciências Biológicas e Biotecnologia da Universidade de Brasília, sobre o tema: a crise do conceito de gene.

Figura 13 Tirinha 11 desenvolvida por estudantes de Ciências Biológicas e Biotecnologia da Universidade de Brasília, sobre o tema: a crise do conceito de gene.

Figura 14 Tirinha 12 desenvolvida por estudantes de Ciências Biológicas e Biotecnologia da Universidade de Brasília, sobre o tema: a crise do conceito de gene. 54

Figura 15 Tirinha 13 desenvolvida por estudantes de Ciências Biológicas e Biotecnologia da Universidade de Brasília, sobre o tema: a crise do conceito de gene.

Figura 16 Tirinha 14 desenvolvida por estudantes de Ciências Biológicas e Biotecnologia da Universidade de Brasília, sobre o tema: o abandono do conceito de gene. 56

Figura 17 Tirinha 15 desenvolvida por estudantes de Ciências Biológicas e Biotecnologia da Universidade de Brasília, sobre o tema: o abandono do conceito de gene. 56

Figura 18 Tirinha 16 desenvolvida por estudantes de Ciências Biológicas e Biotecnologia da Universidade de Brasília, sobre o tema: o abandono do conceito de gene. 56

Figura 19 Tirinha 17 desenvolvida por estudantes de Ciências Biológicas e Biotecnologia da Universidade de Brasília, sobre o tema: o conceito de gene como processos. 57

Figura 20 Tirinha 18 desenvolvida por estudantes de Ciências Biológicas e Biotecnologia da Universidade de Brasília, sobre o tema: o conceito de gene como processos. 57

Figura 21 Tirinha 19 desenvolvida por estudantes de Ciências Biológicas e Biotecnologia da Universidade de Brasília, sobre o tema: o conceito de gene-P e gene-D. 58

Figura 22 Tirinha 20 desenvolvida por estudantes de Ciências Biológicas e Biotecnologia da Universidade de Brasília, sobre o tema: o conceito de gene-P e gene-D. 58

Figura 23 Tirinha 21 desenvolvida por estudantes de Ciências Biológicas e Biotecnologia da Universidade de Brasília, sobre o tema: o conceito de gene definido pelo ENCODE. 59

Figura 24 Tirinha 22 desenvolvida por estudantes de Ciências Biológicas e Biotecnologia da Universidade de Brasília, sobre o tema: genes interrompidos. 59

Figura 25 Tirinha 23 desenvolvida por estudantes de Ciências Biológicas e Biotecnologia da Universidade de Brasília, sobre o tema: herança monogênica. 
Figura 26 Tirinha 24 desenvolvida por estudantes de Ciências Biológicas e Biotecnologia da Universidade de Brasília, sobre o tema: herança monogênica.

Figura 27 Tirinha 25 desenvolvida por estudantes de Ciências Biológicas e Biotecnologia da Universidade de Brasilia, sobre o tema: determinismo genético.

Figura 28 Tirinha 26 desenvolvida por estudantes de Ciências Biológicas e Biotecnologia da Universidade de Brasilia, sobre o tema: determinismo genético. 62

Figura 29 Tirinha 27 desenvolvida por estudantes de Ciências Biológicas e Biotecnologia da Universidade de Brasília, sobre o tema: determinismo genético. 62

Figura 30 Tirinha 28 desenvolvida por estudantes de Ciências Biológicas e Biotecnologia da Universidade de Brasília, sobre o tema: determinismo genético. 62

Figura 31 Resultados da avaliação das atividades pelos estudantes de Ciências Biológicas e Bioecnologia $(n=48)$, por meio do questionário desenvolvido. O grau de concordância atribuído às respostas foram muito, moderado, pouco, nada e não consigo avaliar (NCA). O primeiro resultado se refere (a) à avaliação do material didático, o segundo (b) à analise das aulas teóricas e textos utilizados para a reconstrução do conceito de gene, o terceiro (c) à retomada da tirinha inicial para a reconstrução do conceito de gene, o quarto (d) à elaboração de tirinhas autorais pelos estudantes, e o quinto (e) à toda sequência didática. 


\section{LISTA DE TABELAS}

Tabela 1 Resultados das análises dos conhecimentos prévios sobre o conceito, estrutura e função de gene das tirinhas aplicadas na disciplina de Genética, nos cursos de Ciências Biológicas $(n=61)$, Enfermagem ( $n=62)$ e Biotecnologia $(n=35)$ em porcentagem (\%).

Tabela 2 Visão geral das respostas do conjunto das três tirinhas sobre o conceito, estrutura e função de gene, na disciplina de Genética dos cursos de Ciências Biológicas ( $n=61)$, Enfermagem $(n=62)$ e Biotecnologia $(n=35)$ em porcentagem $(\%)$. 42

Tabela 3 Resultados em relação aos conceitos de gene propostos em reação a crise, que os estudantes de Ciências Biológicas e Biotecnologia $(n=48)$ mais se identificaram, na primeira questão do texto 2 da sequência didática de Nascimento (2010).

Tabela 4 Resultados das avaliações dos conhecimentos prévios e da reconstrução do conhecimento dos estudantes de Ciências Biológicas e Biotecnologia ( $n=38$ ) com relação aos questionamentos das tirinhas "Palestra" e "Genética no bar". Na categoria 1, há a ausência da relação direta na avaliação dos conhecimentos prévios e acrescentaram em sua justificativa os fenômenos discutidos nas aulas na reconstrução. Na categoria 2 , há a relação direta 1:1 na avaliação de conhecimento prévioe a correção desse pensamento na reconstrução. A categoria 3 são respostas reescritas. $E$ na categoria 4 o estudante fez a relação 1:1 no conhecimento prévio e na reconstrução.

Tabela 5 Resultados observados nas respostas dos estudantes de Ciências Biológicas e Biotecnologia $(n=38)$ quanto ao conceito de gene nos conhecimentos prévios e o conceito após a sequência didática, com relação a tirinha "Estudando para a prova". 


\section{LISTA DE ABREVIATURAS E SIGLAS}

DNA da sigla em inglês, Deoxyribonucleic acid

PGH Projeto Genoma Humano

ENCODE Enciclopédia de Elementos do DNA

RNA da sigla em inglês, Ribonucleic acid

mRNA da sigla em inglês, messenger Ribonucleic acid

PNLEM Programa Nacional do Livro para o Ensino Médio

HQ Histórias em Quadrinhos

EDUHQ Projeto de Educação de Ciências Através de Histórias em Quadrinhos 


\section{SUMÁRIO}

1 INTRODUÇÃO 14

1.1 O ENSINO DE GENÉTICA _ 15

1.2 O CONCEITO DE GENE _

1.3 A ARTE NO ENSINO _ 22

2 OBJETIVO 26

2.1 OBJETIVOS ESPECÍFICOS 26

3 MATERIAL E MÉTODOS_ 27

3.1 DESENVOLVIMENTO DO MATERIAL DIDÁTICO - TIRINHAS___ 27

3.2 AVALIAÇÃO DOS CONHECIMENTOS PRÉVIOS SOBRE CONCEITO, ESTRUTURA E FUNÇÃO DE GENE — 28

3.3 PROPOSTA METODOLÓGICA DE USO DAS TIRINHAS NO ENSINO SUPERIOR__ 30

3.3.1 Análise dos resultados __ 33

3.4 ELABORAÇÃO E AVALIAÇÃO DE TIRINHAS AUTORAIS PELOS ESTUDANTES _ 34

3.5 AVALIAÇÃO DO PROCESSO DE ENSINO E APRENDIZAGEM DAS PROPOSTAS POR MEIO DE UM QUESTIONÁRIO __ 35

4 RESULTADOS 37

4.1 DESENVOLVIMENTO DO MATERIAL DIDÁTICO - TIRINHAS___ 37

4.2 AVALIAÇÃO DOS CONHECIMENTOS PRÉVIOS SOBRE CONCEITO, ESTRUTURA E FUNÇÃO DE GENE __ 39

4.3 PROPOSTA METODOLÓGICA DE USO DAS TIRINHAS NO ENSINO SUPERIOR__ 41

4.4 ELABORAÇÃO E AVALIAÇÃO DE TIRINHAS AUTORAIS _ 48

4.5 AVALIAÇÃO DO PROCESSO DE ENSINO E APRENDIZAGEM DAS PROPOSTAS POR MEIO DE QUESTIONÁRIO _ 63

5 DISCUSSÃO 68

5.1 AVALIAÇÃO DOS CONHECIMENTOS PRÉVIOS SOBRE CONCEITO, ESTRUTURA E FUNÇÃO DO GENE _ 68

5.2 PROPOSTA METODOLÓGICA DE USO DAS TIRINHAS NO ENSINO SUPERIOR__ 70

5.3 ELABORAÇÃO E AVALIAÇÃO DE TIRINHAS AUTORAIS

5.4 AVALIAÇÃO DO PROCESSO DE ENSINO E APRENDIZAGEM DAS PROPOSTAS POR MEIO DE QUESTIONÁRIO

6 CONSIDERAÇÕES FINAIS

7 REFERÊNCIAS

ANEXOS

Anexo 1 - Texto utilizado na sequência didática sobre os modelos históricos de gene (Nascimento, 2010). 82

Anexo 2 - Texto utilizado na sequência didática sobre as novas propostas para o conceito de gene (Nascimento, 2010).

Anexo 3 - Artigo publicado na Revista Brasileira de Genética na Escola, Vol. 9, N`2, P. 118 , 2014. 94

Anexo 4 - Artigo publicado na Revista Electrónica de Enseñanza de las Ciências, Vol extra, P. 2695-2700, 2013. 


\section{INTRODUÇÃO}

Devido ao progresso científico e tecnológico, cada vez mais o conhecimento se torna complexo, dificultando o acesso ao público em geral. Isso reforça a ideia de que a ciência é de domínio exclusivo para os pesquisadores, isolando-os em uma atmosfera restrita, devido à deficiência do Ensino de Ciências em esferas mais básicas, distanciando o conhecimento científico do público leigo (1).

A presença da ciência e da tecnologia no cotidiano das pessoas é amplamente reconhecida em assuntos que se centram em temas científicos, como novas vacinas e terapias, alimentos transgênicos, biocombustíveis, clonagem genética, medicina genômica personalizada e outros (2). A incompreensão de determinados conceitos, teorias e processos científicos dificulta a compreensão da leitura e exclui o interesse em se informar dos acontecimentos produzidos no campo da ciência.

Esse panorama pode ser um resultado do ensino tradicional da ciência, que normalmente é muito formal e limitado aos conceitos teóricos, com poucas ou nenhuma prática. Isso possivelmente torna o aluno mais passivo, com pouca participação na aula, sem o entusiasmo de ir além do que o professor ensina. Insistir nesse tipo de ensino acarreta na fraca construção de conhecimentos, que é uma meta importante no desenvolvimento do Ensino e tem como principal consequência a perda de interesse em querer questionar e obter respostas (1).

As implicações de formar e informar dependem dos comportamentos e valores do educador e do educando, onde pode-se atingir um equilíbrio com a educação não-formal com percepções das descobertas científicas e não com a mera repetição de conhecimentos consagrados institucionalmente (3). O desenvolvimento e a implementação de materiais educacionais possibilitam a criação de uma geração que enxerga problemas do estudo da vida de maneira lúdica (1).

Pesquisas na área de ensino evidenciam os problemas que os professores enfrentam ao tentar inserir temas atuais tão necessários para a educação científica almejada. Diversos autores que argumentam a adoção de abordagens que envolvam o aluno mais ativamente no processo de aprendizagem sugeriram como possíveis soluções, alternativas didáticas em que os estudantes sejam capazes de 
resolvê-las, compreendendo os conceitos aplicados e desenvolvendo ideias mais adequadas sobre ciência $(1,3,4,5)$.

Conceitos de genética são desafios no ensino-aprendizagem, especificamente o conceito do gene, onde até os cientistas discordam ao definir este conceito $(6,7,8$, $9,10)$. Neste trabalho está sendo proposta uma nova abordagem didática visando facilitar o melhor entendimento do conceito de gene e suas derivações por estudantes do ensino superior.

\subsection{O ENSINO DE GENÉTICA}

Durante a segunda metade do século XX, o Ensino de Genética tornou progressivamente um campo essencial da Biologia, devido ao avanço do conhecimento científico da área. As implicações éticas presentes em inovações tecnológicas promovem discussões na comunidade científica, perpassando pelos meios de comunicação à agenda de autoridades mundiais (10). Em decorrência principalmente da velocidade com que o conhecimento científico está sendo produzido e da formação inadequada de professores, observa-se um rápido e progressivo acúmulo de problemas conceituais $(10,11)$.

O número de documentários e de programas de popularização do conhecimento científico apresentados nas redes de televisão estão cada vez maiores, ao mesmo tempo que o assunto genética está mais presente na mídia. Do mesmo modo, jornais e revistas dedicam espaços específicos para as novidades da Ciência, principalmente quando têm relação com a saúde ou comportamentos humanos. Apesar da presença reiterada na mídia e da indiscutível relevância, o conhecimento produzido por geneticistas raramente é entendido pelo público, que continua explicando os fenômenos hereditários usando conhecimentos de senso comum (12). Por exemplo, a ideia de que os atributos genéticos estão no sangue persiste apesar do conhecimento sobre o processo de fecundação, da natureza do material hereditário e das leis mendelianas de herança serem amplamente conhecido (13). Termos como gene, cromossomo e DNA estão espalhados na cultura popular, porém a atribuição de significado que se tem na sociedade distanciam dos conceitos científicos (14).

As aplicações da tecnologia genética geraram uma multiplicidade de produtos 
presentes nos meios de comunicação que exigem do estudante um alto nível do conhecimento e compreensão científica. Exemplo disso são questões relativas ao genoma humano, prevenção de doenças genéticas, organismos geneticamente modificados, alimentos transgênicos, terapia gênica, clonagem, dentre outros $(6,10)$.

Além disso, a Genética envolve uma série de assuntos relativos às questões fundamentais sobre a vida, que se direcionam à transmissão e ao desenvolvimento das características, trazendo à tona conceitos e processos ligados à hereditariedade (10). Por isso, diversas dificuldades relativas ao ensino-aprendizado são relatadas na literatura $(5,8,15,16)$.

Uma dificuldade do Ensino de Genética diz respeito à compreensão dos elementos envolvidos na herança. Os estudantes têm uma grande dificuldade em compreenderem a natureza da informação genética e como é passada pelas gerações (10). Um estudo recente reforça a importância de transmitir aos estudantes os novos conhecimentos que se contrapõem à ideia simples da herança monogênica, que ainda persiste no ensino superior (17).

A falta de compreensão do processo da meiose, reprodução sexual, formação dos gametas e geração da diversidade vem sendo apontada como outro fator na dificuldade de ensino e aprendizagem da genética $(7,8)$. Além disso, têm-se ainda outros fatores como o excesso de vocabulário utilizado, a falta de articulação dos conteúdos e a dificuldade de estabelecer relações quando outros conteúdos são abordados, como por exemplo a relação entre gene, genótipo e fenótipo (10).

Há uma contradição entre o desenvolvimento atual e os conceitos básicos da área de genética. Enquanto os campos da Genética e da Biologia Molecular explicam cada vez mais a estrutura do material genético e refinam as possibilidades de intervenção desse material, os conceitos básicos apresentados no Ensino ainda possuem uma visão simplificada e não condizente com a realidade desses novos conhecimentos. A preocupação com a compreensão dos estudantes sobre a natureza dos genes e da informação genética no Ensino de Genética por parte dos professores e profissionais da área de ensino são descritas em diversos trabalhos $(6,8,10,19)$. Dentro desse contexto, a Sociedade Brasileira de Genética vem subsidiando debates e reflexões sobre o ensino de genética, por meio da revista eletrônica "Genética na Escola", criada em 2006, onde se encontram várias propostas e análises. 
O ensino de Genética, na graduação, tem sido basicamente teórico, desprovido de práticas motivadoras e da apresentação de metodologias que gerem produtos nessa área. A facilitação do aprendizado por meio de estratégias do Ensino durante a formação de professores, visa formar e atualizar os profissionais que irão se dedicar ao Ensino médio e/ou fundamental. Estas estratégias não apenas visam possibilitar a inclusão de temas de grande importância, mas também reforçar e estimular a ideia de que o ensino das Ciências deve ser uma atividade dinâmica, originada em vivências concretas.

\subsection{O CONCEITO DE GENE}

O termo "gene" foi introduzido por Wilhelm L. Johannsen, em 1909, numa tentativa de diferenciar fenótipo de genótipo $(6,8)$. O conceito de gene foi certamente um dos marcos da história da ciência no início do século $\mathrm{XX}$, entretanto, a partir de 1980, o futuro deste conceito não parecia promissor. O conceito de gene já foi considerado "sob tensão" (20) e "com problemas" (21), sendo, atualmente, considerado por diversos autores como um conceito em crise $(5,6,22,23,24,25)$.

Os diferentes modelos históricos definidos por Gericke e Hagberg, se basearam na ideia de gene como uma unidade hereditária para o desenvolvimento desses modelos $(8,19)$. Esses modelos, descritos a seguir, são as definições dos conceitos que foram considerados nesse trabalho:

(a) Modelo mendeliano: gene é uma unidade de transmissão e função que produz um traço físico específico, onde não há clareza sobre a existência de uma unidade material na célula.

(b) Modelo clássico: gene é uma unidade de transmissão, função, recombinação e mutação, se localiza no cromossomo e age de modo semelhante a enzima que origina uma característica.

(c) Modelo bioquímico-clássico: gene continua sendo visto como uma unidade de transmissão, função, recombinação e mutação, continua localizado no cromossomo e é responsável pela produção de uma enzima específica que dá origem a uma característica.

(d) Modelo neoclássico, que neste trabalho será referido como molecular clássico, seguindo Griffiths e Neumann-Held (23): gene é uma unidade de 
transmissão, função, estrutura e herança, que é representado por um segmento de DNA ininterrupto, com um começo e fim bem delimitado, se localiza no cromossomo, codifica um produto funcional, que pode ser uma cadeia polipeptídica ou uma molécula de RNA funcional.

A compreensão sobre o genoma e seu funcionamento aumentou consideravelmente em decorrência dos resultados de projetos como o Projeto Genoma Humano - PGH - (26), da Enciclopédia de Elementos do DNA (da sigla em inglês, Deoxyribonucleic Acid) - ENCODE - (27) e do The 1000 Genomes (28). Por outro lado, colaboraram sobremaneira para a atual crise do conceito de gene.

A relação de 1:1:1 entre genes, produtos gênicos e função gênica observada no conceito molecular de gene, direcionou a uma compreensão de unidade genética contestável. A unidade estrutural, representada por um segmento ininterrupto do DNA com limites bem definidos, é confrontada, por exemplo, com a presença de genes interrompidos. Em organismos eucarióticos o gene não é contínuo, apresentando regiões não codificadoras chamadas íntrons e regiões codificadoras chamadas éxons. Os limites de um gene também foram questionados com 0 conhecimento de genes intrônicos, representado pela presença de um gene dentro do íntron de outro gene, admitindo a existência de dois genes em um mesmo locus. Da mesma forma, a presença de elementos regulatórios distantes, como os enhancers e silenciadores, demonstram que as sequências de DNA envolvidas em uma expressão podem estar amplamente separadas uma das outras no genoma. Os genes, portanto, não possuem fronteiras claras e podem se superpor com a presença desses fenômenos (7).

A unidade funcional, que codifica um produto com uma função única, entra em conflito com o fenômeno do splicing alternativo, que leva a geração de diversos transcritos a partir de um gene, originando múltiplos produtos proteicos em um locus genético. Além disso, um segmento de DNA pode codificar para dois produtos proteicos diferentes em diferentes trechos de leitura, representada pelos genes com quadro de leitura sobrepostos, demonstrando que não há a correspondência direta entre DNA e sequência proteica. Os rearranjos gênicos em células somáticas também resultam em muitos produtos gênicos alternativo, tornando o cenário ainda mais complexo $(5,7,8)$.

Ainda, existem diversos outros fenômenos elucidados nas últimas décadas que ampliam essa crise, contestando as unidades genética do conceito molecular 
clássico de gene. Entre eles, os que diminuem a responsabilidade da informação herdada da sequência de DNA. As modificações epigenéticas pode não ser baseada na sequência de DNA, a expressão gênica é dependente da origem do material genético, ou seja, se a fonte foi a materna ou a paterna; da influência do ambiente, entre outros fatores, fazendo com que o fenótipo não seja determinado estritamente pelo genótipo. O RNA mensageiro (mRNA) pode ser modificado enzimaticamente, em um processo conhecido como edição de mRNA, reforçando que a informação contida no DNA não é codificada diretamente em sequências de RNA. Eventos póstraducionais, como o splicing de proteína, possibilitam que produtos proteicos se auto clivem gerando produtos funcionais múltiplos. Os locais de clivagem das sequências proteicas não são determinados pela sequencia gênica $(5,6,7,8,29)$.

Conforme demonstrado acima, as unidades genéticas foram contestadas conforme os avanços da pesquisa em Genética foram surgindo. Diversos autores tentaram adequar o conceito de gene reagindo à crise instaurada, porém essas concepções não substituíram as anteriores, abrindo espaço para a coexistência de múltiplas concepções científicas do gene $(6,8)$. Os modelos, descritos a seguir, são as definições dos conceitos de reação à crise que foram considerados nesse trabalho.

O abandono do conceito de gene foi proposto por alguns pesquisadores $(30,32)$. Esses autores argumentam o peso do discurso biológico a respeito do conceito de gene e propõe que o conceito não deva ser mais utilizado. Contudo, em 2005, Keller afirma que o conceito pode ser mantido, mas que deve ser utilizado com cautela (21).

Nesse sentido, o conceito de gene como processos nega a abordagem de gene como unidades básicas e abre caminhos para um contexto de sistemas genéticos, que inclui as conexões informacionais e dinâmica das células. Dessa forma, o conceito de gene não possui sentido fora da célula e o DNA perde a postura de comando e passa a ser comandado pela célula $(8,21)$.

Uma visão conservadora foi proposta por Griffiths e Neumann-Held, sendo sustentada por uma revisão conceitual que tenta suprir os desafios impostos ao conceito molecular clássico de gene. No conceito molecular processual de gene, o DNA continua sendo uma sequência linear, mas não tem um papel único no desenvolvimento (23). Os genes não são vistos mais como entidades e sim como processos que regulam a expressão de um produto, incluindo os conceitos de 
splicing alternativo e edição de mRNA $(5,8,23)$.Outra forma conservadora de definição, em relação ao conceito molecular clássico de gene, foi a divulgada pelo Projeto Genoma Humano, que definiu gene como uma unidade física e funcional da hereditariedade, onde uma sequência ordenada de nucleotídeos está localizada numa posição particular no cromossomo que codifica um produto funcional: proteína ou RNA (http://ghr.nlm.nih.gov/glossary=gene).

A proposta de gene como processos e o conceito molecular processual de gene tem em comum a definição do conceito de gene considerando os processos envolvidos nas células $(21,23,32)$, implicando que os genes sejam compreendidos de uma maneira mais dinâmica sendo construídos dentro do processo celular (8). De forma semelhante, o conceito sistêmico de gene, sugerido por Pardini e Guimarães, entende sistemas como a célula inteira interagindo com o ambiente, esse sistema seria o correspondente a um banco de dados interativo. Sendo o gene, portanto, definido como uma combinação de sequências de ácidos nucléicos, que pode ser tanto o DNA quanto o RNA, que foi definida pelo sistema para corresponder a um produto, que pode ser tanto o RNA quanto um polipeptídeo $(5,33)$.

Fogle sugeriu um modelo estrutural que caracteriza o conjunto de domínios para transcrição ativa $(32,34)$. Esses domínios são considerados as sequências de nucleotídeos que diferem entre si por suas características estruturais ou funcionais, como éxons, íntrons, promotores, enhancers, dentre outros. Sendo o gene considerado como esses domínios que são combinados para formar conjuntos para a transcrição ativa $(5,7,8)$.

Outros autores, no entanto, não sugeriram um novo conceito de gene, apenas atribuíram outros significados diferenciando o conceito de gene. Por exemplo, 0 conceito de Gene-P e Gene-D descrito por Moss $(24,25)$. O Gene-P se assemelha à compreensão do modelo de gene mendeliano, determinando as diferenças fenotípicas sem se basear numa entidade do genoma. Esse conceito de gene resolve questões relativas a características deterministas que são resultado de uma diversidade de processos que termina no fenótipo apresentado, como comportamento, inteligência, dentre outras, sendo útil na análise de heredogramas e no melhoramento genético onde os cruzamentos são planejados (8). Por sua vez, o gene-D é considerado real, definido por alguma sequência de DNA, que não determina características fenotípicas. A ideia, contudo, é que não há relação entre 
características que sejam determinadas apenas por genes, e sim que as características fenotípicas dependem de uma série de processos genéticos, epigenéticos e ambientais $(5,8)$.

Na proposta resultante do projeto ENCODE, o gene foi entendido como uma união de sequências genômicas que codifica um conjunto de produtos funcionais potencialmente sobrepostos, negando a existência da relação 1:1 entre sequência de DNA e produto funcional, que representam desafios ao modelo molecular clássico de gene $(8,35,36)$.

Adicionalmente a essa crise, observa-se dificuldade na compreensão do conceito básico por parte de todos os atores envolvidos no processo de ensinoaprendizagem da genética. Isso pode ser devido a presença de conceitos vagos e confusos com relação ao conceito de gene, em livros didáticos do ensino médio e superior, além das revistas de divulgação científica, que podem levar a concepções equivocadas $(10,15,29)$. O uso de metáforas para retratar o termo gene em redações de divulgação científica é passível de cuidados para que não haja uma ambiguidade de interpretação (10).

Apesar da importância do conceito de gene para a biologia em geral e, especialmente, para o Ensino de Genética e Biologia Molecular, as discussões realizadas na pesquisa acadêmica sobre o conceito de gene não alcançaram as salas de aula do Ensino Médio e Superior. A informação da crise do conceito e os debates acerca do assunto são escassos tanto nos livros didáticos de Biologia Celular, Molecular e Genética utilizados no Ensino Superior em todo o mundo (15), quanto nos livros de Biologia para o Ensino Médio publicados no Brasil (29).

Com base nos resultados do Programa Nacional do Livro para o Ensino Médio (PNLEM), o conceito molecular clássico de gene, e outras ideias atualmente controversas, é predominante nos livros didáticos de Biologia do Ensino médio, mesmo quando o splicing alternativo já foi abordado $(19,37)$. Os autores defendem a necessidade de incluir, na educação científica de nível médio, uma abordagem mais atualizada do gene e dos fenômenos que desafiam ideias a seu respeito.

Em termos gerais, o tratamento de ideias sobre gene e informação genética nos livros didáticos no Ensino de Biologia deve defender a atualidade do conhecimento aproximando-se da complexidade dos sistemas genéticos, evitando interpretações equivocadas por parte dos estudantes. As interpretações equivocadas por meio de visões deterministas sobre a relação entre gene e fenótipo, 
por exemplo, podem ser fonte de simplificações das relações genótipo-fenótipo e da estrutura dinâmica dos sistemas genômicos encontrados em discursos sobre genes em diferentes esferas de nossa sociedade (29). Seguindo esse pensamento, Nascimento tenta aproximar o conhecimento científico sobre o conceito de gene da realidade do Ensino Superior de Ciências Biológicas propondo uma sequência didática que aborda o tema sob uma perspectiva contextual (8).

Para tanto, não é necessário que os livros didáticos e professores de Biologia estejam informados de todos os novos conhecimentos produzido na área, mas que os principais avanços em discussão ultrapassem a visão determinista sobre o gene, ponderando os modelos propostos sobre a estrutura e função do gene (10).

\subsection{A ARTE NO ENSINO}

Durante o processo de aprendizagem, é indicado que os professores considerem a presença de meios de divulgação de ciência, transformando a sala de aula em um ambiente propício aos alunos terem acesso aos conhecimentos cientificamente aceitos e atuais (3). Uma proposta a ser utilizada para facilitar a inserção do conhecimento científico a partir de uma busca pela leitura é o uso das tirinhas de Histórias em Quadrinhos (HQ). A publicação diária de tirinhas em veículos de comunicação impulsionou a popularização dos quadrinhos a partir de 1930, e, desde então, é um meio de críticas jornalísticas, protestos políticos, relatos do cotidianos e, como aqui mostrado, um instrumento educacional (39).

As tirinhas são sequências narrativas, de dois a cinco quadrinhos, que utilizam linguagem verbal e não verbal para transmitir uma mensagem de caráter opinativo, que geralmente envolve um personagem principal em torno do qual gravitam os outros. Mesmo com um espaço curto, o humor das tirinhas captam a atenção do leitor a partir de uma proposta irônica ou com pluralidade de sentidos (39). As histórias menores ressaltam as imagens e linguagens utilizadas, exigindo dos autores a capacidade de produzir histórias que não promovam a memorização e que despertem a curiosidade. Além das tirinhas serem populares e possuírem uma linguagem acessível, elas podem ter intenção educativa se transformando em um recurso auxiliar para a educação científica, bem como um meio de divulgar ciência $(1,3,38)$. 
A natureza das tirinhas com intuito educativo podem consistir de 1. um conteúdo curricular específico, abordando um determinado conceito de uma disciplina que integre o currículo do Ensino fundamental, médio ou de graduação a ser explorado; 2. um conteúdo extracurricular, com objetivos de abordar conceitos, notícias de avanços científicos e tecnológicos que só são transmitidos aos estudantes por meio da mídia impressa ou televisiva e não pelos livros didáticos ou do ensino formal; 3 . de uma contextualização histórica, onde o desenvolvimento científico se relaciona a outro fato marcante na história; ou 4. da apresentação de situações que reflitam as relações entre ciência e sociedade (3). Esse conjunto de características permitem que o uso de práticas motivadoras como as tirinhas, no ensino de ciências, promovam aos seus leitores uma visão mais críticas das informações recebidas $(4,38,40)$. A produção desse material didático além de permitir a utilização em sala de aula, pode ser abordado também em ensino à distância, servindo como suporte para obter sucesso no desafio da alfabetização científica (3).

O Ensino de Ciências tem buscado espaço nas áreas de pesquisa e diversos estudos do âmbito acadêmico nacional e internacional apresentam propostas de análises e utilização de $\mathrm{HQ}$ como recurso para a educação científica e como meio para divulgar Ciências. A relação entre as $H Q$ e as inúmeras possibilidades de metodologias que esse material possui ganha cada vez mais destaque em pesquisas em Educação para a Ciência. Elaborar metodologias com o uso de tirinhas em sala de aula une esse material ao conteúdo programado com finalidade de ensinar novos conteúdos de forma mais dinâmica e motivadora ao processo de ensino e aprendizagem (1,3). Para tanto, as tirinhas se transformam em um exemplo de como unir ciência e arte, incentivando maior expressão e liberdade de opinião por parte dos estudantes, potencializando a assimilação de conteúdos curriculares, ampliando a criatividade e construindo conhecimentos a partir do imaginário $(40,41)$.

O Projeto de Educação de Ciências Através de Histórias em Quadrinhos (EDUHQ), implementado por Caruso et al., reúne diversos pesquisadores, professores e estudantes do Rio de Janeiro e visa produzir diversos materiais didáticos de forma lúdica, utilizando a linguagem dos quadrinhos, para o ensino fundamental e ensino médio. Nesse projeto, os autores priorizaram características como a criatividade e a liberdade de expressão para a produção de mais de 700 
tirinhas (disponíveis no site www.cbpf.br/eduhq), que abrangem diversas áreas do conhecimento (3).

Cabello et al. apresentam em seu trabalho uma HQ sobre a hanseníase como instrumento de educação, para o ensino fundamental, e de divulgação científica, para ser utilizada em campanhas de conscientização da população. A hanseníase é uma questão da saúde pública Brasileira, onde a falta de informação a respeito do assunto configura um quadro de preconceito perante a sociedade, que dificulta o diagnóstico e o tratamento. Os resultados desse trabalho demonstram que a educação não-formal deste problema de saúde, nos dois contextos sociais analisados, pode auxiliar na correta informação a cerca do assunto (1).

Testoni e Abib desenvolveram uma HQ visando a utilização como uma estratégia didática no contexto do Ensino de Física e, ainda, incentivam os estudantes a desenvolverem suas habilidades desenhando novas histórias de acordo com o que foi discutido. Os resultados desse trabalho indicaram que a estratégia de educação não formal foi bem recebida pelos estudantes de ensino fundamental, que se demonstraram bastantes interessados na dinâmica $(41,42)$.

Com o auxílio do professor, o uso das tirinhas dentro e fora da sala de aula se transformam em uma atividade prática que fornece condições para a construção do conhecimento científico, onde o aluno será capaz de defender as ideias a respeito de conceitos abordados em sala, valorizando a participação ativa do estudante no processo de aprendizagem (38). Um incentivo para o material fomentar discussão pode ser o uso de erros conceituais nas $\mathrm{HQ}$, fazendo-se necessário o papel do professor como mediador das discussões entre a mensagem das tirinhas e do conteúdo curricular da disciplina para que os alunos reconheçam o material como um recurso adicional atrativo para formar consciências (4).

Trabalhos que abordam esse conceito atestam que a discussão envolvendo quadrinhos como instrumento adicional à prática em Ciências começa a se delinear de forma efetiva. Com isso, buscam-se novas alternativas para ensinar Ciências se aproximando cada vez mais dos interesses e da motivação de seus alunos $(1,4)$. Neste sentido, analisar o Ensino de Ciências dentro da sala de aula torna-se essencial para o professor abrir novas possibilidades para a discussão, pois os estudantes são capazes de modificar a dinâmica da aula sendo eles os principais agentes das suas construções de conhecimento (38). 
O ensino tradicional tem levado à fraca construção de conhecimentos e, como consequência, à perda de interesse em querer obter respostas. Os estudantes melhores estimulados poderão desenvolver sua natural curiosidade e o seu potencial criativo para muito além do livro didático. Para isso, situações lúdicas são essenciais para o estímulo da criatividade, relacionamentos sociais e inteligência, podendo facilitar também expressões de emoções, o que é igualmente importante na aprendizagem e na busca de novos conhecimentos. Novas metodologias como as tirinhas podem proporcionar oportunidades ímpares de investigação e exploração (1). 


\section{OBJETIVO}

Desenvolver e testar um material didático, no formato de tirinhas, que facilite a discussão, avaliação de conhecimentos prévios e reconstrução sobre o conceito, estrutura e função do gene.

\subsection{OBJETIVOS ESPECÍFICOS}

- Desenvolver e introduzir tirinhas como recurso didático no aprimoramento e reconstrução do conceito, estrutura e função do gene;

- Testar o novo recurso no Ensino de Genética da Universidade de Brasília;

- Avaliar os conhecimentos prévios dos estudantes da disciplina de Genética da Universidade de Brasília sobre o conceito, estrutura e função de gene;

- Propor e testar uma sequência metodológica com o uso das tirinhas desenvolvidas na reconstrução do conceito, estrutura e função do gene, da disciplina de Genética da Universidade de Brasília;

- Avaliar o processo de ensino-aprendizagem com o uso de tirinhas utilizando questionário específico na disciplina de Genética da Universidade de Brasília. 


\section{MATERIAL E MÉTODOS}

No presente trabalho foi desenvolvido um novo material didático, na forma de tirinhas, e testado na disciplina de Genética da Universidade de Brasília. As tirinhas vem sendo reconhecidas como facilitadora na inserção do conhecimento científico, devido à sua popularidade e linguagem acessivel (1). Planejada com intenção educativa, pode ser utilizada como um recurso para a educação científica e um meio de divulgar ciência. Esse conjunto de características permite o uso das tirinhas como práticas motivadoras, promovendo em seus leitores uma visão mais crítica das informações recebidas $(4,38,40)$.

Foram desenvolvidas três tirinhas buscando enquadrar os desafios, estimular a discussão e o pensamento crítico relacionado ao conceito, estrutura e função do gene. Inicialmente as tirinhas foram utilizadas para avaliar o conhecimento prévio relacionado ao conceito de gene em turmas de graduação em Enfermagem, Ciências Biológicas e Biotecnologia. A segunda aplicação do material foi realizada de forma independente da primeira. Nesse segundo momento, as tirinhas foram utilizadas para fomentar a discussão, desconstrução e reconstrução do conceito de gene por meio de uma proposta metodológica, em turmas de graduação em Ciências Biológicas e Biotecnologia. Em um terceiro momento, após a aplicação da proposta metodológica, os estudantes das turmas de graduação em Ciências Biológicas e Biotecnologia foram incentivados a elaborar tirinhas autorais contextualizando o tema abordado. O processo de ensino-aprendizagem foi avaliado por meio de um questionário. Estas avaliações e aplicações são detalhadas a seguir.

\subsection{DESENVOLVIMENTO DO MATERIAL DIDÁTICO - TIRINHAS}

A proposta desse material originou-se da necessidade de discutir a crise no conceito de gene na graduação e buscar a preparação dos estudantes para receber novos conhecimentos e suas aplicações na sociedade. Para o desenvolvimento das três tirinhas foram definidos: (a) Três temas a serem abordados; (b) um personagem central; (c) o desenho das tirinhas, incluindo enredos; (d) enunciados e questionamentos sobre os temas abordados. 
Os três temas selecionados para serem abordados nas tirinhas foram: (a) o dogma central da biologia, ou seja, um gene: uma proteína; (b) a relação entre a estrutura física do gene e a sequência de aminoácidos de uma proteína; (c) o conceito de gene propriamente dito. A partir da definição dos temas, foi desenvolvido um enredo para cada um. A arte final foi realizada pela artista Luna Rufino.

Visando implementar a conexão dos estudantes ao material didático, foi desenvolvido um personagem principal representando um estudante de graduação cursando a disciplina de Genética. A ideia central foi de que os estudantes, ao serem apresentados às tirinhas, se identificassem com o personagem, ficando confortáveis, estimulados a externarem seus questionamentos e participassem mais ativamente das atividades relacionadas à disciplina. Nas tirinhas, esse personagem foi inserido em três contextos comuns aos estudantes: questionar o conteúdo de palestras, uma conversa em horas de diversão e estudar para uma prova.

Cada tirinha foi acompanhada de um enunciado e um questionamento diretamente relacionado ao tema abordado, além do enredo. Não esperava-se respostas padronizadas, pois esses conhecimentos deveriam ser construídos por meio de consultas, discussões, trocas de ideias e respostas elaboradas espontaneamente. Para a tirinha sobre o Dogma Central da Biologia foi desenvolvido um contexto em que o estudante está em uma palestra e essa tirinha foi denominada "Palestra". O enredo introduziu uma sequência de aminoácido e depois questiona a relação dessa sequência com a sequência do gene responsável. A tirinha "Genética no Bar", mostrou o estudante em uma hora de lazer. O enunciado da tirinha sobre a relação entre estrutura física do gene e o aminoácido de uma proteína incluiu resultados do Projeto Genoma Humano e depois questiona se há uma relação direta entre gene e proteína. Na tirinha sobre o conceito de gene o aluno está estudando para uma prova e consultando diferentes fontes para entender os principais conceitos de Genética e foi denominada "Estudando para a prova". O questionamento nesse caso foi como o estudante define o conceito de gene.

\subsection{AVALIAÇÃO DOS CONHECIMENTOS PRÉVIOS SOBRE CONCEITO, ESTRUTURA E FUNÇÃO DE GENE}


A primeira aplicação das tirinhas teve como objetivo avaliar o conhecimento prévio de estudantes de graduação sobre o conceito, estrutura e função de gene antes de cursarem a disciplina Genética. Nesta proposta buscou-se utilizar o potencial do recurso didático, as tirinhas, em estabelecer conexões por incentivo da estratégia e não por apresentar o conteúdo pronto.

As respostas de estudantes do curso de Ciências Biológicas ( $n=61$, onde $n$ é número de estudantes), Enfermagem $(n=62)$ e Biotecnologia $(n=35)$, sobre o conceito, estrutura e função de gene presente nos enunciados foram avaliadas no início da disciplina Genética na Universidade de Brasília. A diferença do $\mathrm{n}$ amostral desses cursos se dá pelo fato de que esta aplicação foi realizada em dois semestres consecutivos nos cursos de Ciências Biológicas e Enfermagem, enquanto o curso de Biotecnologia só foi avaliado uma única vez, por ser um curso recente na Universidade de Brasília. A disciplina de Genética é ministrada no primeiro semestre letivo para Enfermagem, enquanto para Ciências Biológicas e Biotecnologia é ministrada no quinto semestre letivo, quando estes últimos já cursaram a disciplina Biologia Molecular. Foram considerados todos os estudantes que estavam matriculados na disciplina e que concordaram em participar.

As tirinhas, com seus enunciados e questionamentos, foram apresentadas individualmente aos estudantes, no primeiro dia de aula, antes que qualquer conceito fosse discutido. Foi solicitado que respondessem os questionamentos relativos a cada tirinha utilizando apenas o seu conhecimento prévio ao início da disciplina. Desta forma, solicitou-se que não houvesse conversas entres os alunos e nem consulta a materiais extras (livros, cadernos ou internet) durante a realização da atividade, além de não haver identificação individual nas respostas, garantindo, assim, o anonimato.

Para a análise das respostas dos conhecimentos prévios, foi desenvolvido um gabarito de acordo com o conteúdo esperado como conteúdo prévio, isso é, conteúdo abordado no ensino médio, utilizando um dos livros-textos mais utilizados no ensino médio brasileiro $(37,40)$, conforme pode ser visto no Quadro 1 . Os critérios de correções foram: resposta certa - conteúdo esperado; resposta errada sem o conteúdo esperado; e abstenção - não responderam à avaliação.

Quadro 1 Gabarito desenvolvido de acordo com o conteúdo do livro-texto mais utilizado no ensino médio (Amabis e Martho, 2006) para análise das respostas dos conhecimentos prévios dos 
estudantes dos cursos de Ciências Biológicas, Enfermagem e Biotecnologia sobre o conceito, estrutura e função de gene.

\begin{tabular}{|c|c|}
\hline Tirinha & $\begin{array}{l}\text { Conhecimento esperado pelo aluno } \\
\text { recém ingressado no ensino superior }\end{array}$ \\
\hline Palestra & $\begin{array}{l}\text { É esperado, que o estudante tenha conhecimento (1) do } \\
\text { "Dogma central da Biologia Molecular", onde há a } \\
\text { correlação informacional entre DNA, RNA e proteína (1 } \\
\text { gene: } 1 \text { produto funcional); (2) das características do código } \\
\text { genético. (3) de que geralmente a sequência do gene não } \\
\text { poderá ser inferida completamente. }\end{array}$ \\
\hline Genética no bar & $\begin{array}{l}\text { Espera-se que os estudantes correlacionem o "Dogma } \\
\text { central da Biologia Molecular" e o "Conceito molecular } \\
\text { clássico de gene", onde o gene seja visto como unidade de } \\
\text { estrutura e função, mostrando que não há relação direta de } \\
1 \text { gene: } 1 \text { proteína. }\end{array}$ \\
\hline Estudando para a prova & $\begin{array}{l}\text { É esperado que os estudantes saibam o conceito molecular } \\
\text { clássico de gene. No conceito molecular clássico, o gene é } \\
\text { considerado (1) uma sequência de DNA que (2) codifica um } \\
\text { produto funcional, que pode ser tanto um (3) polipeptídeo } \\
\text { quanto uma molécula de RNA, que, por sua vez, (4) terá } \\
\text { uma única função. }\end{array}$ \\
\hline
\end{tabular}

\subsection{PROPOSTA METODOLÓGICA DE USO DAS TIRINHAS NO ENSINO SUPERIOR}

Foi desenvolvida uma proposta metodológica para o uso das tirinhas no ensino superior com a finalidade de reconstrução do conceito de gene a partir da promoção do pensamento crítico, discussão e a busca de informações na forma de uma sequencia didática. A proposta foi composta de três etapas: (a) apresentação e utilização das tirinhas para verificar os conhecimentos prévios; (b) aulas teóricas e uso de textos específicos, baseados no trabalho de Nascimento (8) e (c) revisita das tirinhas. A sequência didática foi dividida em quatro encontros, onde as tirinhas com enunciados e questionamentos foram aplicadas aos estudantes em duas situações diferentes. O objetivo dessa sequencia foi aumentar a complexidade do conceito de gene por meio da desconstrução do conhecimento prévio com base na apresentação de novidades teóricas atuais.

O primeiro encontro com os estudantes visou registrar o conhecimento prévio destes. Para tanto, as tirinhas com questionamentos foram distribuídas individualmente no primeiro dia de aula, após a apresentação da disciplina e antes que qualquer conceito fosse discutido com o professor. Foi recomendado que não 
houvesse conversas entres os colegas e nem consulta a materiais extras (livros, cadernos ou internet). Não foi imposto um tempo aos estudantes para a realização dessa atividade, visando que os mesmos respondessem com calma.

No segundo encontro foi apresentada uma aula teórica, de aproximadamente 40 minutos, onde buscou-se interação com os estudantes por meio de perguntas. $\mathrm{O}$ tema da aula foi a História dos conhecimentos sobre Hereditariedade e Genética, com enfoque na evolução do conceito do gene, até as descobertas de Watson e Crick, em 1953. Nessa aula foi discutido, dentre outros, a origem do termo gene, as definições dos modelos de gene mendeliano, clássico e bioquímico (19) e a proposta da estrutura do DNA em dupla hélice por Watson e Crick em 1953, que permitiu uma visão mais realista do conceito de gene por meio do modelo molecular clássico.

Após a aula expositiva foi utilizada parte de outra sequência didática, desenvolvida por Nascimento (8), que apresenta uma revisão sobre os modelos históricos de gene, que foram trabalhados em sala de aula durante a sequência didática aqui proposta. Durante essa parte da atividade, os alunos foram organizados em duplas para a leitura, discussão e resolução dos exercícios do Texto 1 (Anexo A) que aborda o desenvolvimento dos modelos históricos de gene, suas aplicações e limitações. Os estudantes ficaram livres para interagir com seu colega de dupla e a professora caminhou pela sala a disposição para tirar dúvidas dos estudantes. Com relação a esse texto, foram consideradas para esse trabalho as respostas à questão 1, que apresenta mapas conceituais dos modelos históricos do conceito de gene. As demais questões do texto de Nascimento (8), sobre o conceito da visão instrumentalista e realista, não foram aqui abordadas, pois não são do escopo desse trabalho.

Durante o terceiro encontro foi apresentada uma aula teórica em sequência à aula anterior, isto é, a evolução do conceito de gene a partir do trabalho de Watson e Crick em 1953. No mesmo formato da aula anterior, a aula teórica foi de aproximadamente 40 minutos e questionou as ideias de unidades (genética, estrutural, funcional e informacional) expostas no conceito molecular clássico, demonstrando os motivos da crise do conceito de gene. Foram, então, exemplificados os fenômenos que problematizam esse conceito, como o mecanismo do operon-lac, genes interrompidos, splicing alternativo, mecanismos de expressão gênica, regulações pós-transcricionais, regulações pós-traducionais, pseudogenes e modificações químicas na cromatina. O professor falou a maior parte do tempo, mas, 
como na aula anterior, buscou interação com os estudantes por meio de perguntas. Após a aula expositiva, os estudantes foram organizados em duplas e novamente foi utilizada parte da sequência didática sugerida por Nascimento (8). Nessa parte da atividade os alunos realizaram a leitura, discussão e resolução dos exercícios do Texto 2 (Anexo B), sobre as propostas de revisão conceitual que buscam superar os desafios ao modelo molecular clássico. Os estudantes ficaram livres para interagir com seu colega de dupla e a professora caminhou pela sala à disposição para tirar dúvidas dos estudantes. Ainda foi sugerida uma leitura complementar ao assunto, o artigo Genética em transformação (7), disponibilizado de modo virtual para os alunos. Foram consideradas para esse trabalho as respostas à questão 2, sobre conceito de gene. A questão 1, que investigou se o estudante conseguiu identificar semelhanças nos conceitos de gene apresentados, não foi avaliada por não estar no escopo deste trabalho.

No quarto e último encontro, o objetivo foi motivar os estudantes a reconstruir o conceito de gene por meio de consultas em meios científicos e discussões sobre o tema. As tirinhas respondidas na primeira aula retornaram aos estudantes para que, em duplas, fossem novamente respondidas estimulando o pensamento crítico e reflexivo. Foi recomendado aos estudantes que consultassem os textos disponibilizados nas aulas. Os estudantes ficaram livres para interagir com seu colega de dupla e a professora caminhou pela sala à disposição para tirar dúvidas dos estudantes. Os estudantes precisaram de aproximadamente 40 minutos para responderem aos conhecimentos prévios e 60 minutos para reconstruir os conceitos. Todos os estudantes demonstraram interesse durante a execução da atividade, discutindo com colega de dupla, e alguns chamaram a professora para dar um direcionamento nas atividades.

Esta sequência didática foi aplicada para os cursos de Ciências Biológicas (diurno e noturno) e Biotecnologia pela docente responsável pela disciplina. Só foram consideradas as respostas dos alunos que participaram de todas as atividades e que consentiram em participar $(n=38)$. Em ambos os cursos selecionados, a disciplina de Genética tem como pré-requisito a disciplina Biologia Molecular. Essa proposta foi realizada independentemente da aplicação anterior (avaliação dos conhecimentos prévios), o que significa que foram aplicadas em semestres diferentes. 


\subsubsection{Análise dos resultados}

A abordagem adotada para a análise desses resultados foi descritiva, pois os dados coletados foram sustentados por citações retiradas das respostas dos estudantes sobre os questionamentos presentes nas tirinhas. Na análise da tirinhas "Palestra" foi verificada a relação entre a sequência de aminoácido e a sequência de DNA, enquanto na tirinha "Genética no bar" foi verificada a relação entre gene e proteína. Foram registradas as possibilidades de respostas, com a finalidade de observar a construção do novo pensamento. Para tanto, foram criadas quatro categorias de classificação:

Categoria 1: Avaliação de conhecimento prévio - ausência da relação direta 1:1. Reconstrução - continuaram sem fazer a relação direta e acrescentaram em sua justificativa os fenômenos discutidos nas aulas, como por exemplo, a existência de íntrons e éxons, splicing, edição de RNA e modificações pós-traducional.

Categoria 2: Avaliação de conhecimento prévio - fazem relação direta 1:1. Reconstrução - param de fazer a relação direta e acrescentam em sua justificativa os fenômenos discutidos nas aulas, como por exemplo, a existência de íntrons e éxons, splicing, edição de RNA e modificações pós-traducional.

Categoria 3: Avaliação de conhecimento prévio - ausência de relação direta 1:1. Reconstrução - reescreveram a mesma resposta.

Categoria 4: o estudante fez a relação 1:1 no conhecimento prévio e na reconstrução.

Para a análise da tirinha "Estudando para a prova", as respostas fornecidas pelos estudantes foram classificadas de acordo com o conceito de gene identificado. Nas respostas dos conhecimentos prévios foram considerados os modelos históricos (15): mendeliano, clássico, bioquímico, molecular clássico e sem conceito, para aqueles que não conseguiram definir gene. $\mathrm{Na}$ reconstrução do conceito, foram avaliadas a presença da crise do conceito de gene e se houve preferência por alguma proposta de revisão conceitual (4): gene como processos, conceito sistêmico de gene, conjunto de domínios para transcrição ativa, conceito molecular processual de gene, gene-P e gene-D, conceito de gene no Projeto Genoma Humano e conceito de gene do Encode. 


\subsection{ELABORAÇÃO E AVALIAÇÃO DE TIRINHAS AUTORAIS PELOS ESTUDANTES}

Buscando estimular o estudante para a leitura, o estudo e a contextualização do conceito do gene, foi proposto que eles construíssem tirinhas autorais em grupos e depois as apresentassem a turma. Essa didática foi aplicada para as mesmas turmas da proposta metodológica de uso das tirinhas no ensino superior, isso é, os cursos de Ciências Biológicas (diurno e noturno) e Biotecnologia, da Universidade de Brasília. Para este trabalho, foram consideradas as atividades dos alunos que consentiram em participar $(n=52)$ e contou com a presença da docente da disciplina em sala.

Visando o planejamento que a atividade requer, a docente repassou as instruções aos estudantes com duas semanas de antecedência das apresentações. Os estudantes foram organizados em duplas e/ou triplas e, excepcionalmente, individualmente. Nesta instrução houve ainda direcionamentos quanto à arte das tirinhas para que os estudantes não perdessem o foco durante a elaboração, pois o importante era a abordagem do assunto e não a estética do desenho. Para tanto, sugeriu-se que os estudantes pudessem utilizar desenhos próprios, montagens, quadrinhos existentes ou sites especializados, como o www.makebeliefscomix.com. Decorrido o tempo de elaboração das tirinhas autorais, as tirinhas foram apresentadas para suas respectivas turmas pelos seus autores. Foi disponibilizado o tempo de 5-10 minutos para os estudantes exporem a tirinha elaborada, explicarem o enfoque, o contexto e, em alguns casos, possíveis leituras alternativas que o material desenvolvido poderia oferecer.

$\mathrm{Na}$ análise dos resultados foi assumida uma metodologia qualitativa, os dados foram de natureza principalmente descritiva, pois o ambiente da sala de aula foi uma das fontes de dados e as descrições foram sustentadas por citações retiradas das respostas dos estudantes. As tirinhas elaboradas pelos estudantes foram classificadas de acordo com o assunto que abordaram dentro do tema da evolução do conceito de gene: crise do conceito, abandono do conceito, o conceito de gene como processos, o conceito de gene-P e gene-D, o conceito de gene do ENCODE, genes interrompidos, herança mendeliana, determinismo genético e fenótipo. 


\subsection{AVALIAÇÃO DO PROCESSO DE ENSINO E APRENDIZAGEM DAS PROPOSTAS POR MEIO DE UM QUESTIONÁRIO}

Foi desenvolvido um questionário com o objetivo de avaliação, por parte dos estudantes, do material e das atividades aqui propostos. Neste, buscou-se que as instruções fossem claras e objetivas, além de estarem ao nível de entendimento dos estudantes. $\mathrm{O}$ elemento de identificação do questionário foi retirado, garantindo o anonimato. Um total de 42 estudantes dos cursos de Ciências Biológicas (diurno e noturno) e Biotecnologia, da Universidade de Brasília, responderam ao questionário.

O modelo de questionário adotado foi o misto, por possuir tipos de questões com respostas abertas e fechadas. As questões de respostas abertas permitem a liberdade de expressão, porém geram respostas mais variadas, complicando a interpretação objetiva. As questões de respostas fechadas possibilitam selecionar a opção mais adequada à opinião e facilita a categorização das respostas para a análise (44). As questões fechadas seguiram o modelo de escala, baseado na Escala de Likert, onde a resposta especifica o grau de concordância com a pergunta realizada, sendo atribuído um número, que reflete a direção da intenção de resposta em relação a cada pergunta (44).

O questionário foi composto por cinco partes buscando abranger os pontos trabalhados: (a) análise das tirinhas; (b) avaliação da proposta didática; (c) avaliação do retorno às respostas iniciais fornecidas pelos estudantes; (d) avaliação da elaboração das tirinhas pelos estudantes; (e) avaliação da sequência didática total. Cada etapa do questionário consiste de duas perguntas fechadas e uma aberta. Ao final do questionário, há um campo aberto para comentários positivos, negativos e sugestões. O questionário desenvolvido encontra-se na Figura 1. 


\section{QUESTIONÁRIO}

O presente questionário tem como principal objetivo avaliar a sequência didática do tema "evolução do conceito de gene" durante as aulas da disciplina de Genética.

\begin{tabular}{|c|c|}
\hline $\begin{array}{l}\text { Para cada afirmação (de } 1 \text { a } 10 \text { ) assinale o número da escala que melhor } \\
\text { reflete a sua opinião relativa à sequência didática da "evolução do conceito } \\
\text { de gene". }\end{array}$ & $\begin{array}{l}0 \text { - Não consigo avaliar } \\
1 \text { - Nada } \\
2 \text { - Pouco } \\
3 \text { - Moderado } \\
4 \text { - Muito }\end{array}$ \\
\hline
\end{tabular}



\begin{tabular}{|l|l|l|l|l|l|}
\hline Texto 1 + Texto 2 + Aulas teóricas & 0 & $\mathbf{1}$ & $\mathbf{2}$ & $\mathbf{3}$ & $\mathbf{4}$ \\
\hline
\end{tabular}

3. Os textos 1 e do texto 2 trabalhados em sala de aula facilitaram seu entendimento sobre o atual desenvolvimento científico sobre o tema?

4. As aulas teóricas, que antecederam as atividades dos textos, contribuíram para o seu

entendimento?

- Comentários e sugestões:

\section{Reconstrução do conceito de gene}

5. Foi eficiente retomar a tirinha inicial para reconstruir o seu conhecimento sobre o tema?

6. O tema foi trabalhado por meio de novas ideias, perguntas e pontos de vista diferentes?

- Como você avalia as suas respostas nas tirinhas após a atividade de reconstrução do conhecimento?

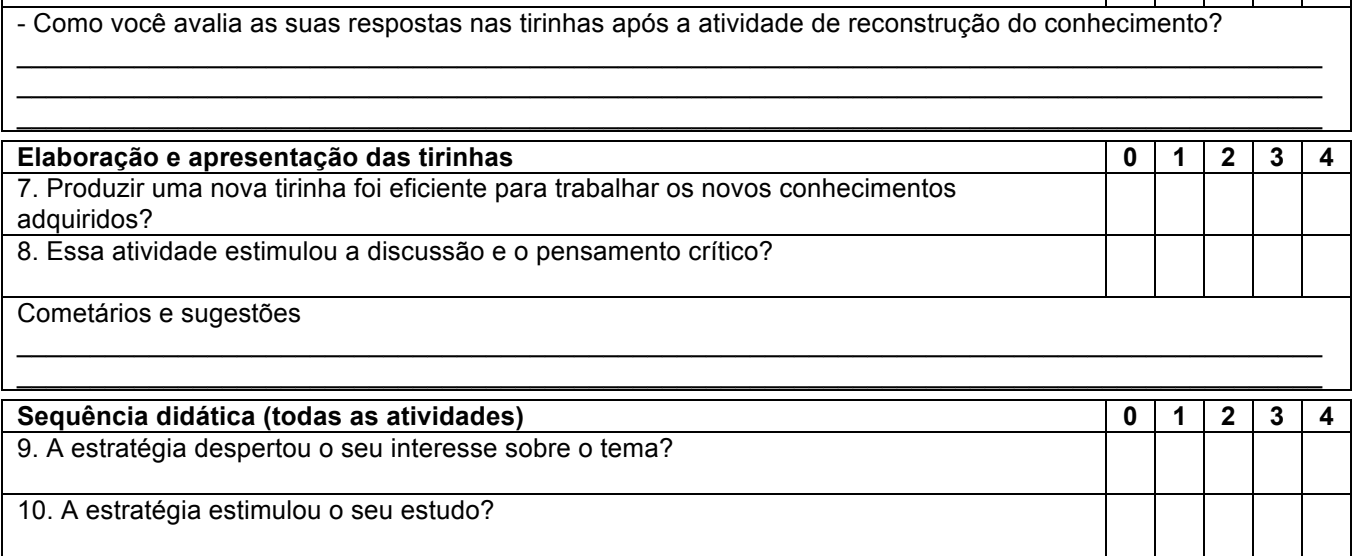

- Destaque aspectos positivos, negativos e sugestões sobre a sequência didática apresentada?



Obrigada pela colaboração!

Figura 1 Questionário de questões mistas, aplicado aos estudantes de Ciências Biológicas e Biotecnologia, desenvolvido para verificar se os objetivos das atividades propostas foram atingidos após a sequência didática. 


\section{RESULTADOS}

\subsection{DESENVOLVIMENTO DO MATERIAL DIDÁTICO - TIRINHAS}

Foram desenvolvidas três tirinhas (Figura $\mathbf{2}$ a, $\mathbf{b}$ e $\quad$ c) e respectivos enunciados e questionamentos:

1. "Palestra" (Figura 2a). Retrata a participação de estudantes em eventos como seminários, palestras ou congressos e objetivou abordar a relação entre a estrutura física do gene e a sequência de aminoácidos de uma proteína, de uma maneira inversa ao que é tradicionalmente ensinado no Dogma Central da Biologia Molecular.

2. "Genética no bar" (Figura 2b). Aqui foi priorizado o caráter argumentativo dos estudantes, enquanto questionou a relação "um gene: uma proteína" após os resultados do Projeto Genoma Humano. Essa atividade visa proporcionar ao estudante a organização dos seus conhecimentos para depois explicá-los e justificálos, mesmo que para uma platéia fora do meio acadêmico.

3. "Estudando para a prova" (Figura 2c). Nessa tirinha buscou-se dinamizar o questionamento do conceito de gene. Nesse contexto, o personagem foi apresentado estudando e consultando diferentes fontes a respeito de diversos conceitos da área de Genética. Foi aqui apresentado o desafio de fazer a conexão entre o conhecimento atual, que inclui as recentes descobertas sobre a estrutura, a organização e a regulação do gene, dentre outras, e a definição de gene. 
(a)

Em uma palestra sobre a descoberta sobre uma nova proteina em uma espécie de feijão, o pesquisador descreve a sequência de aminoácidos. Leia a tirinha. Qual seria a resposta adequada para a dúvida levantada pelo estudante?
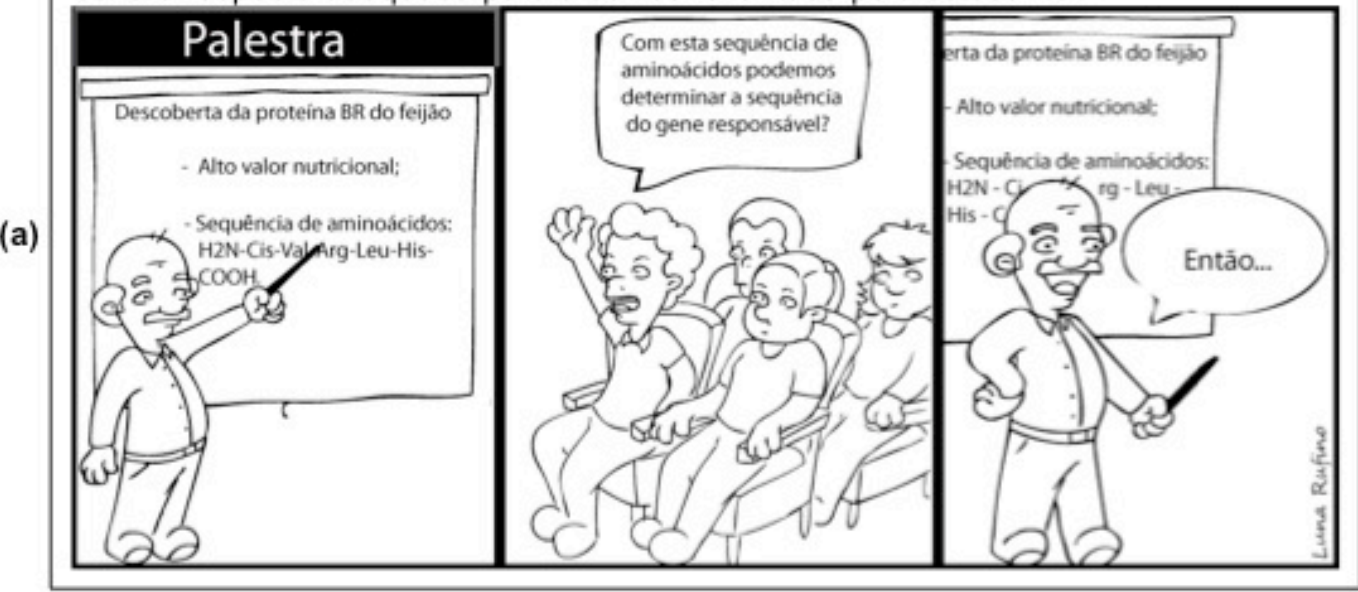

Em uma mesa de bar surge um papo informal entre dois estudantes sobre os resultados do Projeto Genoma Humano. Leia a tirinha. Ao ouvir esse papo, o que diria?

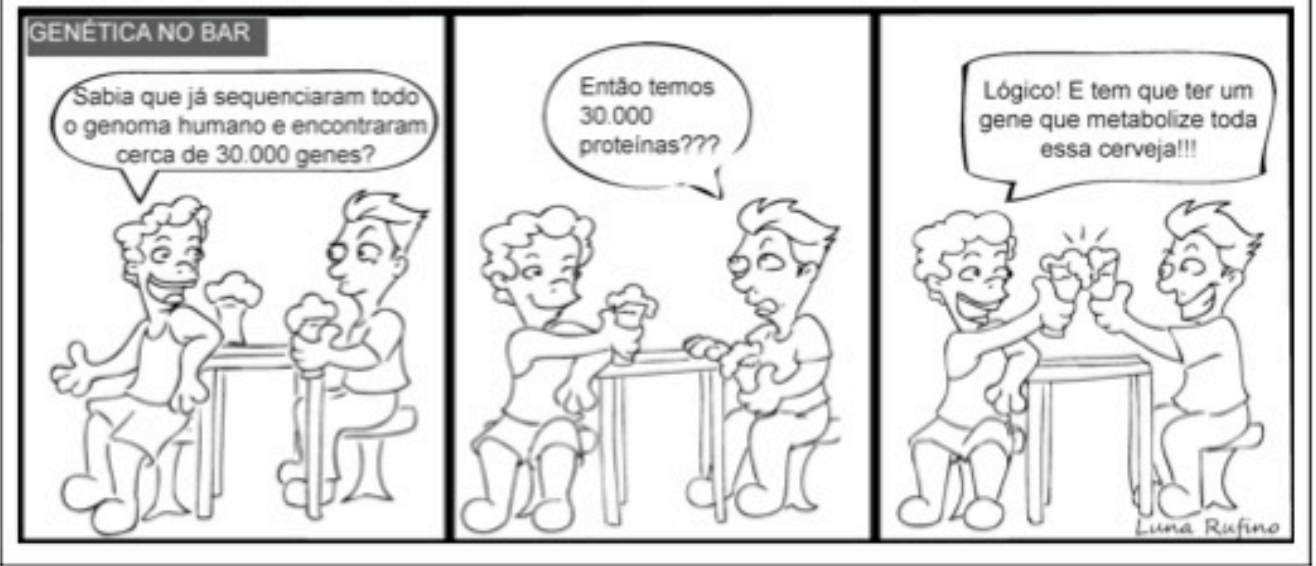

Tentando entender os principais conceitos da Genética, o estudante consulta diferentes fontes. Confiante em seu aprendizado, ele se sente preparado para novos desafios. Leia a tirinha. Como você definiria o conceito de gene?

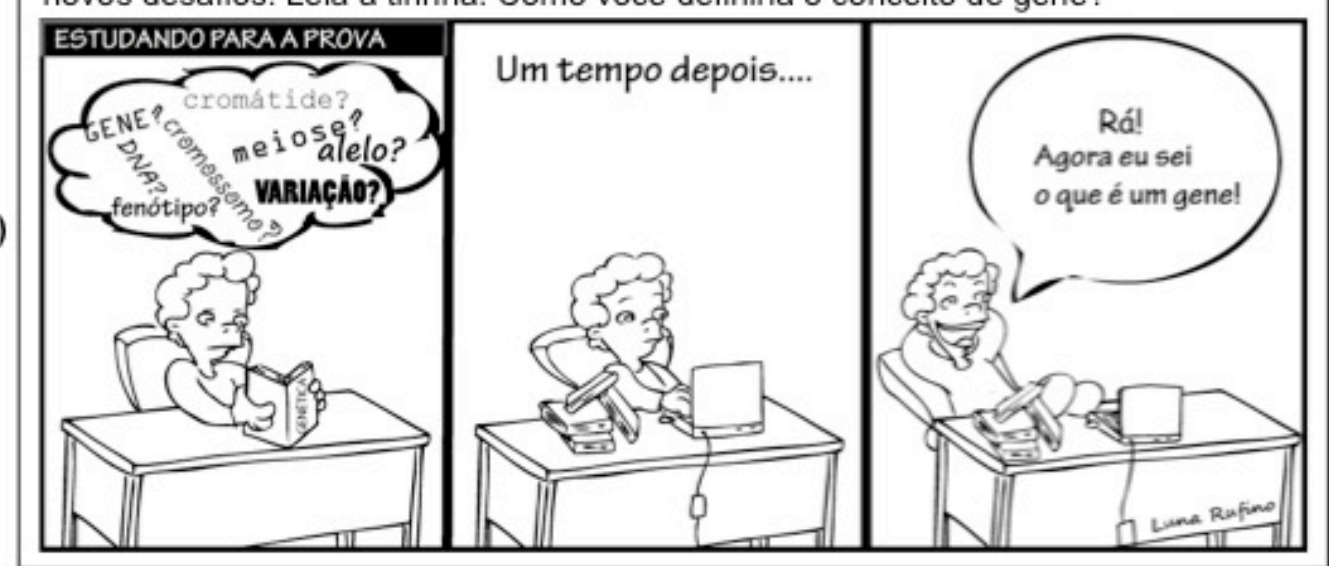

Figura 2 As três tirinhas desenvolvidas com os seus respectivos enunciados e questionamentos. (a) A tirinha "Palestra" aborda a estrutura do gene e sua relação com a sequência de aminoácido. (b) $A$ tirinha "Genética no bar" prioriza o caráter argumentativo dos estudantes sobre a relação um gene: uma proteína. (c) A tirinha "Estudando para a prova" aborda o conceito de gene. 


\subsection{AVALIAÇÃO DOS CONHECIMENTOS PRÉVIOS SOBRE CONCEITO, ESTRUTURA E FUNÇÃO DE GENE}

Os resultados das análises das respostas dos estudantes aos questionamentos de cada tirinha estão apresentados nas Tabelas 1 e 2. Classificouse como abstenção os questionários que foram entregues em branco. Para a tirinha "Palestra", todos os alunos de Biotecnologia responderam à questão proposta, não havendo, portanto, nenhuma abstenção nesse curso. A porcentagem de abstenções dos estudantes do curso de Enfermagem foi a maior $(16,1 \%)$.

Quanto às respostas classificadas como erradas, observou-se que a maioria dos estudantes de Enfermagem fez a relação direta da sequência de aminoácidos com a sequência de nucleotídeos do gene $(67,7 \%)$. O motivo do erro foi que a maioria desses alunos fizeram a relação direta da sequência de aminoácidos com a sequência de nucleotídeos do gene. Os alunos que não fizeram a relação direta cometeram erros conceituais ou demonstraram uma confusão do conteúdo, como "Genes codificam aminoácidos”, “(...) os aminoácidos agrupados formam códons”, "os aminoácidos estão ligados às proteínas que os genes carregam" e "os aminoácidos fazem parte da composição do gene".

Nas respostas classificadas como certas, a maioria dos estudantes dos cursos de Biotecnologia (82,9\%) e Ciências Biológicas (62,3\%) acertaram essa questão, entendendo que não existe relação direta entre a sequência de aminoácido e a sequência do gene. Apesar disso, observou-se respostas mais estruturadas dos estudantes do curso de Biotecnologia do que dos de Ciências Biológicas, como, por exemplo, "Não seria possível pois alguns aminoácidos são codificados por diferentes códons", demonstrando que o conhecimento sobre a redundância do código genético está mais consolidado nesses alunos. Em contrapartida, são os estudantes de Ciências Biológicas que citam mais conhecimentos além do esperado, como genes interrompidos (presença de íntrons e éxons), "processamento de RNA", "splicing"; enquanto o splicing foi o único fenômeno citado pelos alunos de Biotecnologia.

$\mathrm{Na}$ tirinha "Genética no bar", todos os estudantes de Biotecnologia responderam corretamente o questionamento sobre a relação gene: proteína, afirmando que essa relação não é de 1:1, bem como $90 \%$ dos estudantes do curso 
de Ciências Biológicas, demonstrando que esse conceito está claro para os estudantes de ambos os cursos. Por outro lado, observou-se que cerca de metade dos estudantes do curso de Enfermagem responderam a questão de forma correta e metade de forma errada. Observou-se que parte dos estudantes não apresentaram justificativas coerentes (Biotecnologia - 22,9\%; Ciências Biológicas - 16,4\%; Enfermagem - 14,5\%). Citações sobre o splicing alternativo foram detectadas em respostas de todos os cursos, que superaram as expectativas deste trabalho. As respostas classificadas como erradas apresentaram confusão de conceitos nas justificativas para a relação errônea 1 gene: 1 proteína, predominantemente nos estudantes de Enfermagem.

Erros conceituais foram observados em todos os cursos. Exemplos disso foram "genes são constituídos de proteínas" e "o nosso código genético possui regiões denominadas íntrons e éxons". No entanto, encontramos diversas respostas elaboradas no curso de Biotecnologia, ultrapassando as expectativas, que incluíam fenômenos como "íntrons", "éxons", "splicing", "modificações pós-traducionais", "genes de RNA". Além disso, foi interessante notar que os estudantes criticaram a ideia de gene-centrismo presente na tirinha, com comentários como: "não é o gene que metaboliza a cerveja"; além de perceber a interação dos alunos com a tirinha com comentários como: "Que burro!".

A tirinha "Estudando para a prova" foi a única tirinha em que observou-se abstenções de respostas no curso de Biotecnologia e, ainda, a maior porcentagem de respostas classificadas como erradas nos cursos, com prevalência de ideias errôneas e confusas. Como, por exemplo, de que gene "é genótipo", "é uma sequência de aminoácido", "cromossomo", "é o princípio da divisão celular", dentre outros. Foi nesta análise, das respostas classificadas como erradas, que se detectou a maior aproximação porcentual entre os dois cursos de Ciências Biológicas $(60,7 \%)$ e Enfermagem $(77,4 \%)$, no entanto, as definições do conceito de gene foram diferentes. Na Enfermagem e na Biotecnologia, o conceito predominante foi "gene mendeliano", enquanto nas Ciências Biológicas foi o "gene bioquímico-clássico".

O conhecimento do conceito molecular clássico do gene foi demonstrado em cerca de $50 \%$ das respostas classificas como certas dos estudantes de Biotecnologia, 34\% dos estudantes de Ciências Biológicas e para apenas 11\% dos estudantes de Enfermagem. Dentro deste conhecimento não há clareza nas respostas sobre quais produtos funcionais são originados, e quando citados houve 
predominância da "proteína" e omissão do "RNA" ou "polipeptídeo". Os estudantes de Biotecnologia, mais uma vez, apresentaram respostas mais adequadas ao esperado.

As avaliações das respostas do conjunto das três tirinhas estão apresentadas na Tabela 2. A porcentagem de respostas certas para as três tirinhas em conjunto foi de $27 \%$ nas Ciências Biológicas, 22,9\% na Biotecnologia e de 3,2\% na Enfermagem. A porcentagem de respostas erradas para as três tirinhas foi de 45,2\% na Enfermagem, aproximadamente $10 \%$ nas Ciências Biológicas e zero na biotecnologia, onde nenhum estudante errou a tirinha Genética no bar. Na sequência onde há respostas erradas somente na tirinha Estudando para a Prova observamos uma grande discrepância entre os cursos (Biotecnologia - 60\%; Ciências Biológicas - 32,8 e Enfermagem - 4,8\%).

\subsection{PROPOSTA METODOLÓGICA DE USO DAS TIRINHAS NO ENSINO SUPERIOR}

Foi observado que $83,3 \%$ dos estudantes obtiveram uma boa visualização dos mapas conceituais presentes nos exercícios do texto 1 (Anexo A), com auxílio da aula didática e do texto e 16,7\% não apresentaram resultados satisfatórios à mesma. Com relação às respostas à questão 2 do texto 2 (Tabela 3), observa-se que o conceito mais aceito por metade dos estudantes foi o do ENCODE, que define o gene como "uma união de sequências genômicas que codificam um conjunto de produtos funcionais potencialmente sobrepostos". Observou-se também que 12\% dos estudantes selecionaram o conceito molecular processual de gene, que define gene como "um processo que ocorre repetidas vezes e conduz à expressão regulada de um produto polipeptídico particular".

A Tabela 4 apresenta os resultados das avaliações das respostas prévias e da reconstrução dos conceitos das tirinhas "Palestra" e "Genética no Bar", que demonstra o percentual de melhora após a sequência didática em relação aos conhecimentos iniciais. 
Tabela 1 Resultados das análises dos conhecimentos prévios sobre o conceito, estrutura e função de gene das tirinhas aplicadas na disciplina de Genética, nos cursos de Ciências Biológicas ( $n=61)$, Enfermagem $(n=62)$ e Biotecnologia $(n=35)$ em porcentagem $(\%)$.

\begin{tabular}{|c|c|c|c|c|}
\hline \multirow[t]{2}{*}{ Tirinha } & \multirow{2}{*}{$\begin{array}{l}\text { Classe de } \\
\text { Respostas }\end{array}$} & \multicolumn{3}{|c|}{ Curso de Graduação } \\
\hline & & Ciências Biológicas & Enfermagem & Biotecnologia \\
\hline \multirow{3}{*}{ Palestra } & Certo & 62,3 & 16,1 & 82,9 \\
\hline & Errado & 32,8 & 67,7 & 17,1 \\
\hline & Abstenções & 4,9 & 16,1 & 0,0 \\
\hline \multirow{3}{*}{ Genética no bar } & Certo & 88,5 & 43,5 & 100,0 \\
\hline & Errado & 6,5 & 45,2 & 0,0 \\
\hline & Abstenções & 8,2 & 11,3 & 0,0 \\
\hline \multirow{3}{*}{ Estudando para a prova } & Certo & 34,4 & 11,3 & 51,4 \\
\hline & Errado & 60,7 & 77,4 & 42,9 \\
\hline & Abstenções & 4,9 & 11,3 & 5,7 \\
\hline
\end{tabular}

Tabela 2 Visão geral das respostas do conjunto das três tirinhas sobre o conceito, estrutura e função de gene, na disciplina de Genética dos cursos de Ciências Biológicas $(n=61)$, Enfermagem $(n=62)$ e Biotecnologia $(n=35)$ em porcentagem $(\%)$.

\begin{tabular}{lllccc}
\hline Palestra & $\begin{array}{c}\text { Genética } \\
\text { no bar }\end{array}$ & $\begin{array}{c}\text { Estudando } \\
\text { para } \\
\text { prova }\end{array}$ & & \multicolumn{2}{c}{ Curso de graduação } \\
\cline { 3 - 5 } & & & $\begin{array}{c}\text { Ciências } \\
\text { Biológicas }\end{array}$ & Enfermagem & Biotecnologia \\
\hline Certo & Certo & Certo & 27,9 & 3,2 & 22,9 \\
Certo & Certo & Errado & 32,8 & 4,8 & 60,0 \\
Certo & Errado & Certo & 0,0 & 1,6 & 0,0 \\
Certo & Errado & Errado & 1,6 & 6,5 & 0,0 \\
Errado & Certo & Certo & 6,6 & 3,2 & 0,0 \\
Errado & Certo & Errado & 21,3 & 32,3 & 17,1 \\
Errado & Errado & Certo & 0,0 & 3,2 & 0,0 \\
Errado & Errado & Errado & 9,8 & 45,2 & 0,0 \\
\hline
\end{tabular}


Tabela 3 Resultados em relação aos conceitos de gene propostos em reação à crise, que os estudantes de Ciências Biológicas e Biotecnologia $(n=48)$ mais se identificaram, na primeira questão do texto 2 da sequência didática de Nascimento (2010).

\begin{tabular}{lc}
\hline \multicolumn{1}{c}{ Conceitos propostos } & $\begin{array}{c}\text { Quantidade de } \\
\text { alunos (\%) }\end{array}$ \\
\hline Abandono do conceito & 0,0 \\
Genes como processos & 8,3 \\
Conceito sistêmico de gene & 4,2 \\
Conjunto de domínios para a transcrição ativa & 4,2 \\
Conceito molecular processual de gene & 12,5 \\
Gene-P e Gene-D & 8,3 \\
Conceito de gene do Projeto Genoma Humano & 8,3 \\
Genon e Transgenon & 4,2 \\
ENCODE & 50,0 \\
\hline
\end{tabular}

Tabela 4 Resultados das avaliações dos conhecimentos prévios e da reconstrução do conhecimento dos estudantes de Ciências Biológicas e Biotecnologia $(n=38)$ com relação aos questionamentos das tirinhas "Palestra" e "Genética no bar". Na categoria 1, há a ausência da relação direta na avaliação dos conhecimentos prévios e acrescentaram em sua justificativa os fenômenos discutidos nas aulas na reconstrução. Na categoria 2, há a relação direta 1:1 na avaliação de conhecimento prévio a correção desse pensamento na reconstrução. A categoria 3 são respostas reescritas. E na categoria 4 o estudante fez a relação 1:1 no conhecimento prévio e na reconstrução.

\begin{tabular}{ccc}
\hline Categorias & $\begin{array}{c}\text { Palestra } \\
(\mathbf{\%})\end{array}$ & $\begin{array}{c}\text { Genética no bar } \\
(\mathbf{\%})\end{array}$ \\
\hline 1 & 52,6 & 84,2 \\
2 & 34,2 & 7,9 \\
3 & 10,5 & 7,9 \\
4 & 2,6 & 0,0 \\
\hline
\end{tabular}

Para a tirinha "Palestra", observou-se que na categoria 1 e 2 houve uma melhora substancial para quase todos maioria dos estudantes $(86,8 \%)$ pois após a sequência das aulas e dos textos, estes foram capazes de reformular respostas mais elaboradas, com o acréscimo de diversos fenômenos que reforçam a afirmação da ausência de correlação 1:1 sequencia de aminoácidos e sequencia de DNA. Os mais citados foram: excisão de íntrons, splicing alternativo, modificações pós-traducionais, edição de RNA, efeitos pós-transcricionais e genes com quadro de leitura sobrepostas. 
$\mathrm{Na}$ categoria 1, foi observado uma baixa porcentagem $(2,6 \%)$ de indivíduos que inicialmente não relacionaram uma sequência de aminoácido com uma sequência de DNA por conta da redundância do código genético. Porém estes demonstraram uma confusão no pensamento, e, por fim, agregaram mais conhecimentos trabalhados às respostas, como a excisão de íntrons, splicing alternativo e modificações pós-traducionais.

As respostas dos estudantes que fizeram a relação de 1:1 entre a sequência de aminoácido e a sequência do gene estão na categoria 2 . É interessante observar que esses estudantes começaram com um conceito ultrapassado e, após a sequência didática, passaram a entender que essa relação não é possível se consideramos os novos conhecimentos abordados em sala de aula.

Cerca de $10 \%$ de estudantes não fizeram a relação direta entre a sequência de aminoácido e a sequência de nucleotídeos do gene na resposta dos conhecimentos prévios (Categoria 3). No entanto, a segunda resposta não foi reconstruída de acordo com os novos conhecimentos e sim reescrita. Este dado é diferente do $2,6 \%$ dos estudantes da categoria 4 que fizeram a relação direta e continuaram a fazer após a sequência didática.

As avaliações das respostas prévias junto com a construção do conceito de gene da tirinha "Genética no bar" também se encontram na Tabela 4 e encontram-se descritas a seguir.

Foi observado que $92,1 \%$ dos estudantes não fizeram a relação direta entre sequência do gene e proteína, devido à presença de fenômenos como splicing alternativo ou pela existência de função regulatória. Na categoria 1 , as respostas reconstruídas foram elaboradas com maior riquezas de fenômenos bem definidos pelos estudantes, tendo como os mais citados: splicing alternativo, splicing de proteína, trans-splicing de RNA, função regulatória, modificações pós-traducionais, edição de RNA, excisão de íntrons, genes com quadro de leitura sobrepostas, pseudogenes e outros.

Uma pequena porcentagem $(7,9 \%)$ dos estudantes foi incluída na categoria 2. Esses estudantes começaram com um conceito ultrapassado e passaram a entender que essa relação não é possível se considerarmos os conhecimentos abordados em sala de aula. 
Para as respostas da categoria 1 e 2, notou-se que a maioria dos estudantes não foi capaz de nomear os fenômenos propriamente nas respostas dos conhecimentos prévios, conceituando-os superficialmente. Contudo, após a sequência das aulas e dos textos, esses estudantes foram capazes de formular respostas melhores, aperfeiçoando o que escreveram primeiro e definindo os fenômenos trabalhados em sala de aula corretamente.

A categoria 3 apresentou uma porcentagem de quase $8 \%$ dos estudantes que não fizeram a relação direta entre a sequência do gene e a sequência da proteína na resposta que verificava os conhecimentos prévios. No entanto, a segunda resposta não foi reconstruída de acordo com os novos conhecimentos e sim reescrita.

Nesta tirinha os alunos interagiram com a historia através de comentários como: "Vocês estão bêbados" ou "Isso é papo furado". Também houveram manifestações de fuga ao gene-centrismos com argumentações como "Genes não são responsáveis por metabolizar nada" ou "Não é o gene que metaboliza a cerveja".

Os resultados com relação a tirinha "Estudando para a prova" constam na Tabela 5 e encontram-se comentadas a seguir.

$\mathrm{Na}$ classificação Molecular Clássico $\rightarrow$ Molecular Clássico, a definição da resposta dos conhecimentos prévios veio acompanhada de confusão, além não haver a correlação do RNA como produto final. Por exemplo, "O gene é uma sequência de DNA que compreende o start códon até o códon stop, e é potencialmente codificadora de proteínas". $\mathrm{Na}$ reconstrução esses erros são corrigidos, como podemos conferir a seguir: "O gene é uma sequência de DNA que é potencialmente codificadora de um produto funcional, podendo ser uma cadeia polipeptídica ou molécula de RNA".

As respostas da classificação Molecular Clássico $\rightarrow$ Molecular Clássico (+) mantiveram o conceito molecular de gene incluindo na reconstrução a ideia da crise do conceito de gene. A definição desse conceito nos conhecimentos prévios não correlacionou o RNA como produto, apenas a proteína, como por exemplo, "É uma sequência de nucleotídeos que codifica uma proteína e encontra-se armazenado no DNA". Já na definição 
reconstruída, o RNA passa a ser um produto, porém a inclusão da crise no conceito gerou algumas respostas com conceitos errôneos ou confusão, como pode-se observar nesta resposta: "Segundo o modelo molecular clássico, o gene é um segmento de DNA que codifica um produto final (proteína ou mRNA), sem interrupções e com começo e fim definidos. Todavia, este conceito está sendo posto em dúvida visto que estudos recentes com DNA eucariótico e procariótico, descobriram novos mecanismos que contrariam o antigo conceito. O DNA eucariótico não é ininterruptos pois ocorre excisão de íntrons. E também existem sequências de DNA, os genes regulatórios, que não são transcritos e então não codificam um produto final, logo não são considerados unidade funcional".

Todas as respostas reconstruídas que foram classificadas como Molecular Clássico (+) mostram que não houve opção por nenhum outro modelo apresentado. Não obstante, fatores referentes à crise foram acrescentados nas definições: "Sequência de nucleotídeos que pode ser transcrita em um mRNA ou polipeptídeo juntos com as suas sequências regulatórias como íntrons, promotores, intensificadores, operadores etc. e não existe relação de 1:1 entre uma sequência codificadora no nível do DNA e um produto funcional."

Tabela 5 Resultados observados nas respostas dos estudantes de Ciências Biológicas e Biotecnologia $(n=38)$ quanto ao conceito de gene nos conhecimentos prévios e o conceito após a sequência didática, com relação à tirinha "Estudando para a prova".

\begin{tabular}{lc}
\hline \multicolumn{1}{c}{ Conhecimentos prévios $\rightarrow$ Construção } & $\begin{array}{c}\text { Quantidade de } \\
\text { alunos (\%) }\end{array}$ \\
\hline Sem conceito $\rightarrow$ Molecular Clássico & 13,2 \\
Sem conceito $\rightarrow$ Molecular Clássico $(+)$ & 2,6 \\
Mendeliano $\rightarrow$ Molecular Clássico $(+)$ & 10,5 \\
Mendeliano $\rightarrow$ Gene como Processos & 2,6 \\
Mendeliano $\rightarrow$ Conjunto de Domínios para Transcrição Ativa & 2,6 \\
Mendeliano $\rightarrow$ Encode & 2,6 \\
Bioquímico $\rightarrow$ Gene como Processos & 2,6 \\
Molecular Clássico $\rightarrow$ Molecular Clássico & 15,8 \\
Molecular Clássico $\rightarrow$ Molecular Clássico $(+)$ & 23,7 \\
Molecular Clássico $\rightarrow$ Gene como Processos & 10,5 \\
Molecular Clássico $\rightarrow$ Conceito Sistêmico de Gene & 2,6 \\
Molecular Clássico $\rightarrow$ Conjunto de Domínios para Transcrição Ativa & 2,6 \\
Molecular Clássico $\rightarrow$ Conceito Molecular Processual de Gene & 2,6 \\
Molecular Clássico $\rightarrow$ Encode & 2,6 \\
Molecular Clássico $\rightarrow$ Falk & 2,6 \\
\hline
\end{tabular}


Para a maioria das respostas reconstruídas constaram a escolha pelo tradicional conceito molecular de gene acrescido da ideia da crise do conceito, contudo houveram opções onde os novos conceitos foram escolhidos. O conceito de gene como processos foi a escolha de $13,1 \%$ dos estudantes e argumenta que "o significado de um gene não está contido na sequência de nucleotídeos do DNA, mas emerge como um processo que envolve o sistema pelo qual os genes são interpretados, que inclui a célula e, em alguns casos, até mesmo o ambiente supracelular". O conceito de conjunto de domínios para transcrição ativa foi a escolha de 5,2\% dos estudantes, que reconhece que o gene "é construído pela reunião de domínios encontrados no DNA". O conceito de gene do ENCODE foi a escolha de $5,2 \%$ dos estudantes e define gene como "uma união de sequências genômicas que codificam um conjunto de produtos funcionais potencialmente sobrepostos". A escolha de 2,6\% dos estudantes foi o conceito sistêmico de gene, que define gene como "uma combinação de (uma ou mais) sequências de ácidos nucléicos (DNA ou RNA), definido pelo sistema (a célula inteira interagindo com o ambiente) que corresponde a um produto (RNA ou polipeptídeo)". E por ultimo, o conceito molecular processual de gene foi o desfecho de $2,6 \%$ dos estudantes e define gene como "um processo que ocorre repetidas vezes e conduz à expressão regulada de um produto polipeptídico particular".

A classificação Molecular Clássico $\rightarrow$ Falk foi a resposta baseada em um trecho da conclusão do artigo sugerido como leitura complementar, "Genética em transformação", onde a autora relata a visão instrumentalista de Falk: "Hoje o gene não é a unidade material ou a unidade instrumental da herança, mas é, antes, uma unidade, um segmento que corresponde à função de uma unidade, conforme definida pelas necessidades do experimentador" (45).

Finalmente, um estudante ao reconstruir o conhecimento tentou definir o conceito do gene em meio a tantos novos conhecimentos: "Gene é o conjunto de sequências nucleotídicas não-contínuas que codificam e regulam a expressão de produtos funcionais variados cuja origem advenha desse conjunto codificante em comum. Onde lê-se produtos funcionais considere 
RNAs e polipeptídeos que contribuam inteira ou parcialmente para a construção de produtos funcionais, moléculas estas com variações de origem".

\subsection{ELABORAÇÃO E AVALIAÇÃO DE TIRINHAS AUTORAIS}

As tirinhas elaboradas pelos estudantes foram classificadas de acordo com o assunto que abordaram dentro do tema da evolução do conceito de gene. Os assuntos abordados foram a crise do conceito de gene, abandono do conceito de gene, o conceito de gene como processos, o conceito de Gene-P e Gene-D, o conceito de gene do ENCODE, genes interrompidos, herança monogênica, determinismo genético e fenótipo.

Foram retratadas 13 tirinhas, ao total, sobre a crise do conceito de gene, onde foi abordado a dificuldade de conceituar gene e a dificuldade de se posicionar a respeito da crise do conceito. Adicionalmente, a maioria dos estudantes afirmaram que não sabiam da existência dessa crise antes da professora abordar o tema e ainda acrescentaram que se identificaram com as dinâmicas apresentadas por outros estudantes. A dúvida da crise de identidades das estruturas afetou a maioria dos estudantes, que se mostraram interessados em abordar esse ângulo para demonstrar o quanto é difícil conceituar gene. Por fim, a dúvida de como conceituar gene permaneceu em finalizações feitas pelos estudantes durante as apresentações: "como verbalizar esse conhecimento?", "o conceito está sendo montado". Nas tirinhas que serão citadas a seguir não há explanação de dúvidas dos estudantes, apenas a exemplificação da dificuldade que encontraram em definir o conceito de gene.

A tirinha apresentada na Figura 3 mostra o reconhecimento dos estudantes que se identificaram ao ver o DNA e o gene em crise. Já na tirinha da Figura 4 é apresentada uma montagem em analogia ao pensamento de um fotógrafo renomado, Sebastião Salgado, onde se enxerga o presente sem se esquecer do passado, onde o gene passa a ser um quebra cabeça sem consenso sobre o que é. Em uma referencia ao filme "O guia dos mochileiros da galáxia" (um filme de Douglas Adams, 2005), a 
dificuldade do sentido da vida é comparada à dificuldade de conceituar gene (Figura 5).

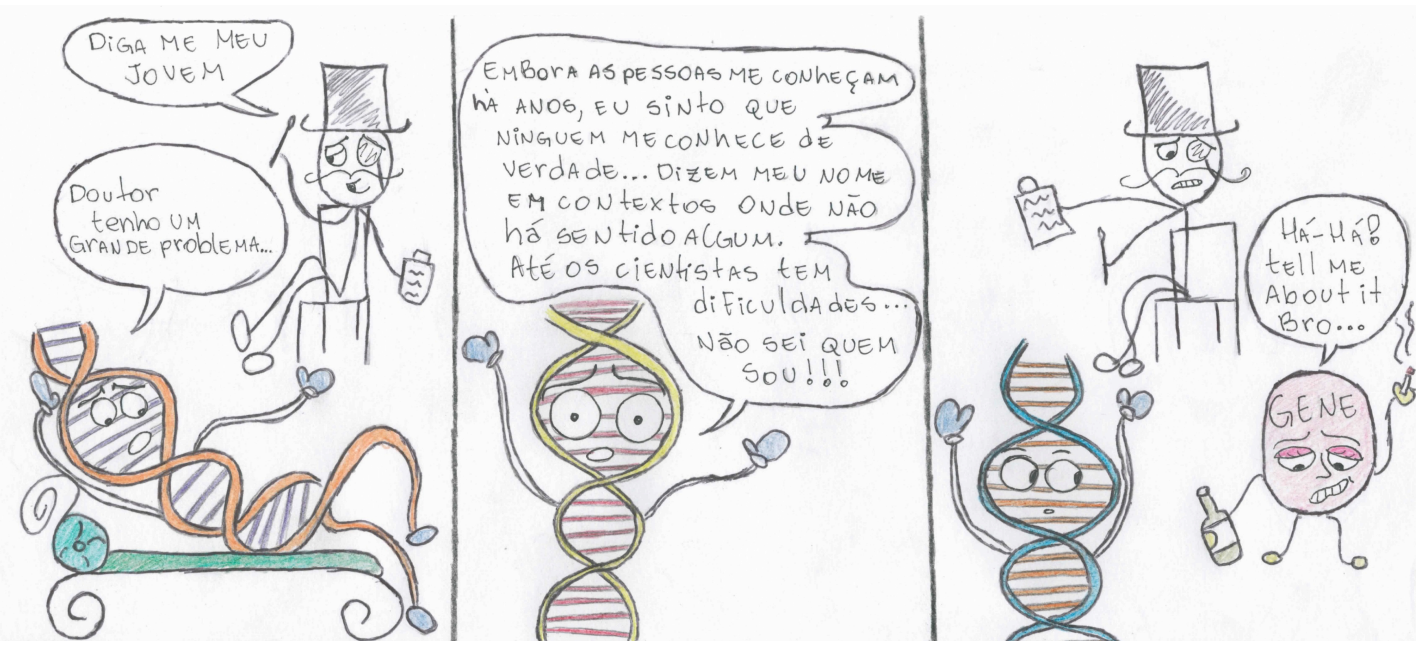

Figura 3 Tirinha 1 desenvolvida por estudantes de Ciências Biológicas e Biotecnologia da Universidade de Brasília, sobre o tema: a crise do conceito de gene.

Em outra montagem, Mendel fica chateado pois o fenótipo não é influenciado apenas pelo "par de fatores genéticos" (Figura 6). Na tirinha apresentada Figura 7 foi demonstrado o quanto é difícil conceituar gene, mesmo quando diversos cientistas estão trabalhando no assunto, com a ajuda do "Pink e o Cérebro" (desenho de Tom Ruegger e Steven Spielberg, 1995)

Os cientistas às voltas com a definição de gene...

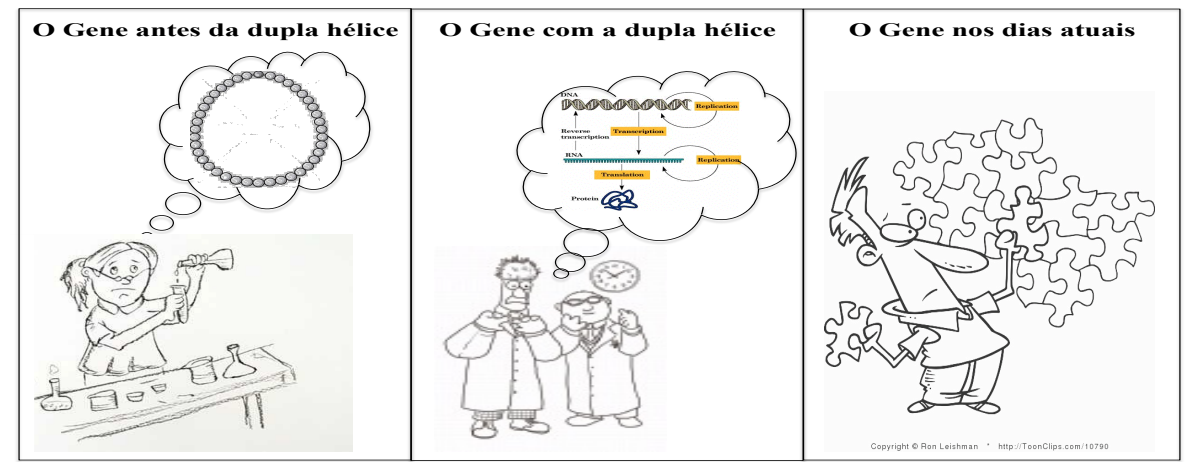

Figura 4 Tirinha 2 desenvolvida por estudantes de Ciências Biológicas e Biotecnologia da Universidade de Brasília, sobre o tema: a crise do conceito de gene. 


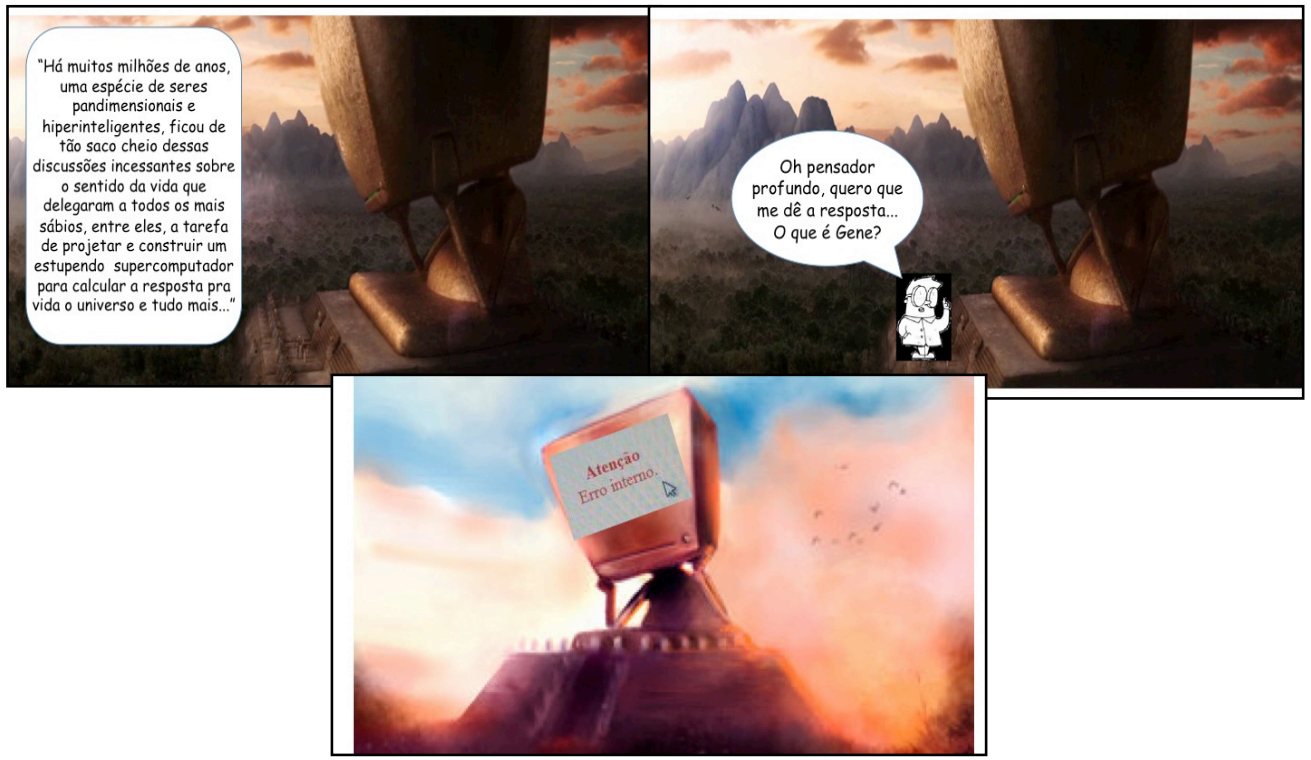

Figura 5 Tirinha 3 desenvolvida por estudantes de Ciências Biológicas e Biotecnologia da Universidade de Brasília, sobre o tema: a crise do conceito de gene.

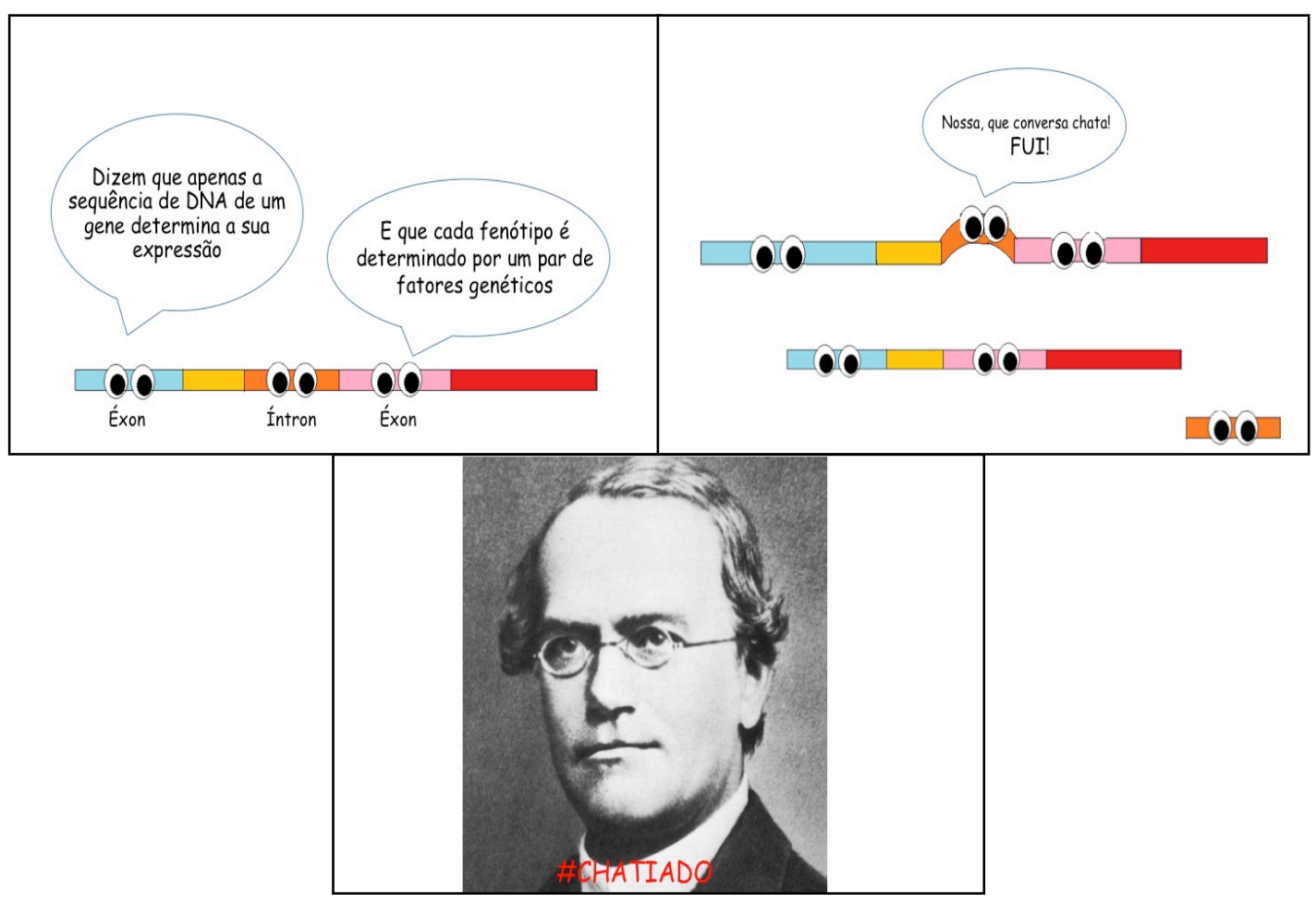

Figura 6 Tirinha 4 desenvolvida por estudantes de Ciências Biológicas e Biotecnologia da Universidade de Brasília, sobre o tema: a crise do conceito de gene. 




Figura 7 Tirinha 5 desenvolvida por estudantes de Ciências Biológicas e Biotecnologia da Universidade de Brasília, sobre o tema: a crise do conceito de gene.

Uma resposta filosófica em meio a tantas questões define a resposta sobre o que é gene em uma das tirinhas: "só sei que nada sei" (Figura 8). Na tirinha da Figura 9, os estudantes sugeriram uma outra abordagem para a discussão da crise do gene. Um desenho demonstra uma luta livre, onde os combatentes são o modelo mendeliano, representado por Mendel e o conceito molecular clássico, representado pelo cromossomo. Os responsáveis por essa tirinha sugerem que uma forma de trabalhar os conceitos é confrontando-os. Os outros estudantes da turma, apesar de terem gostado da representação do Mendel, não conseguiram enxergar aonde encaixariam as novas informações. 


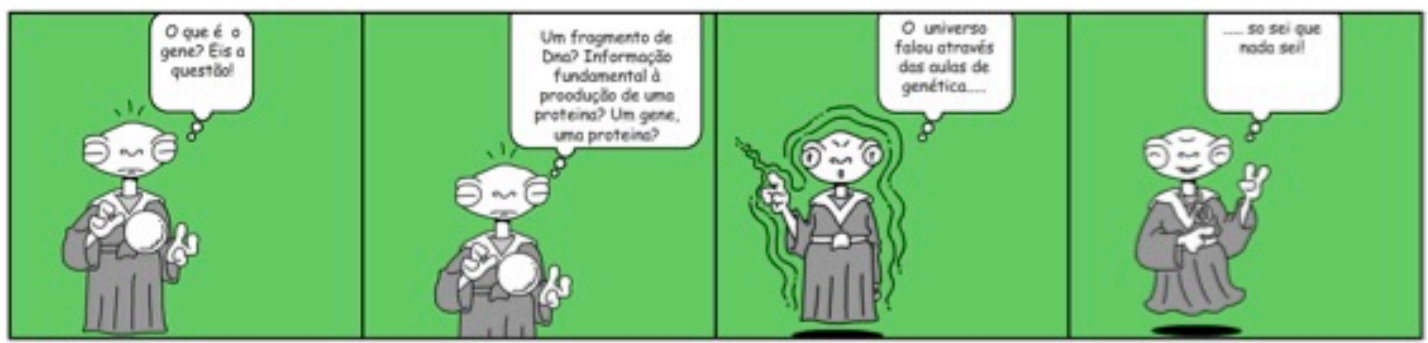

Figura 8 Tirinha 6 desenvolvida por estudantes de Ciências Biológicas e Biotecnologia da Universidade de Brasília, sobre o tema: a crise do conceito de gene
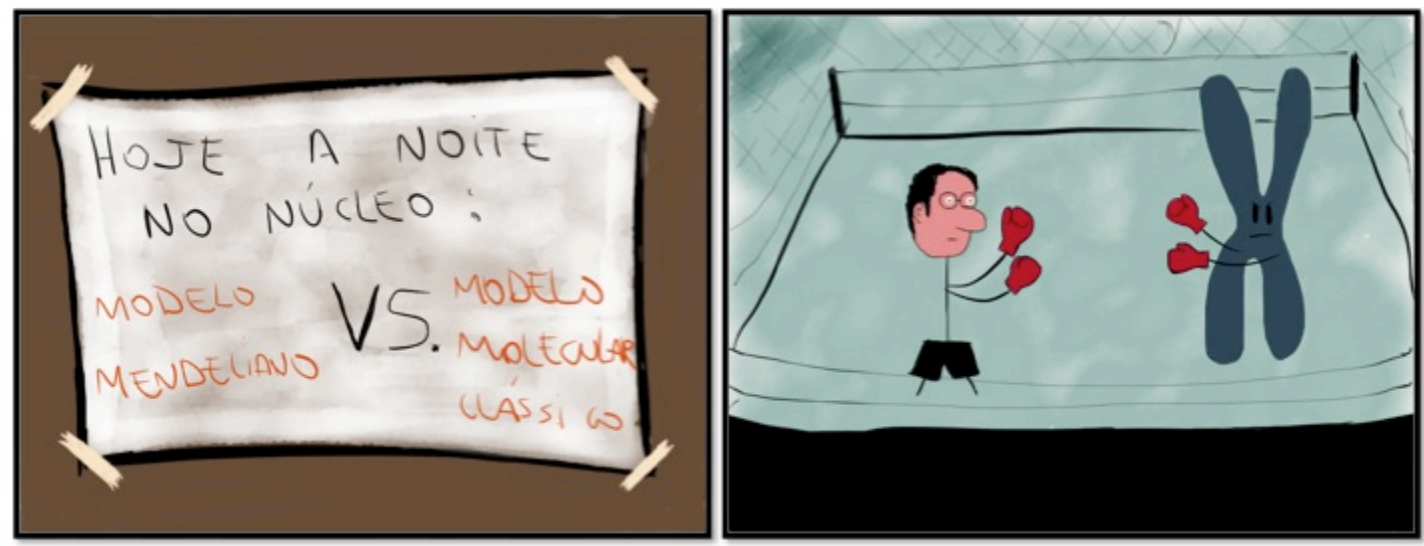

Figura 9 Tirinha 7 desenvolvida por estudantes de Ciências Biológicas e Biotecnologia da Universidade de Brasília, sobre o tema: a crise do conceito de gene.

Duas tirinhas se basearam na segurança de que pessoas mais velhas podem nos ajudar a entender melhor as dúvidas e abriram caminhos para discutir dois pontos principais: a crise do conceito e a evolução do conceito de gene (Figura 10 e 11). Essas tirinhas sugerem que a crise do conceito de gene deve ser refletida. 


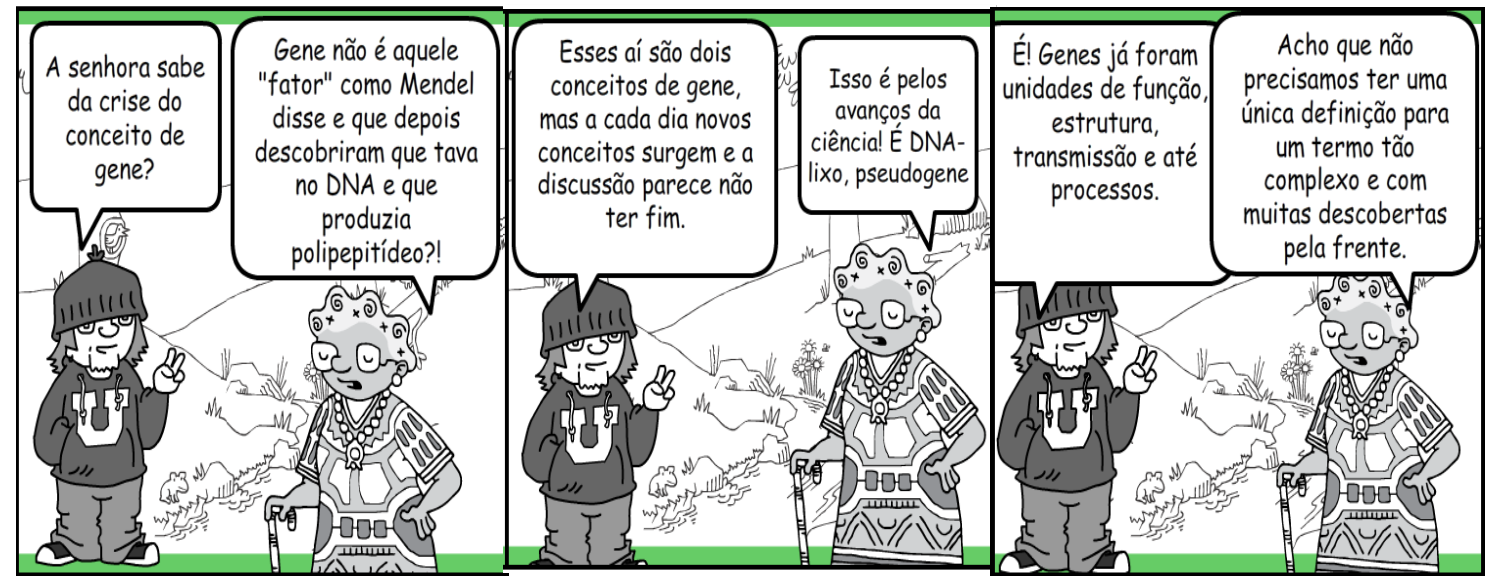

Figura 10 Tirinha 8 desenvolvida por estudantes de Ciências Biológicas e Biotecnologia da Universidade de Brasília, sobre o tema: a crise do conceito de gene.

\section{AVÔ, PAI E FLLHO - 0 GENE E SUAS GERAÇOEES}
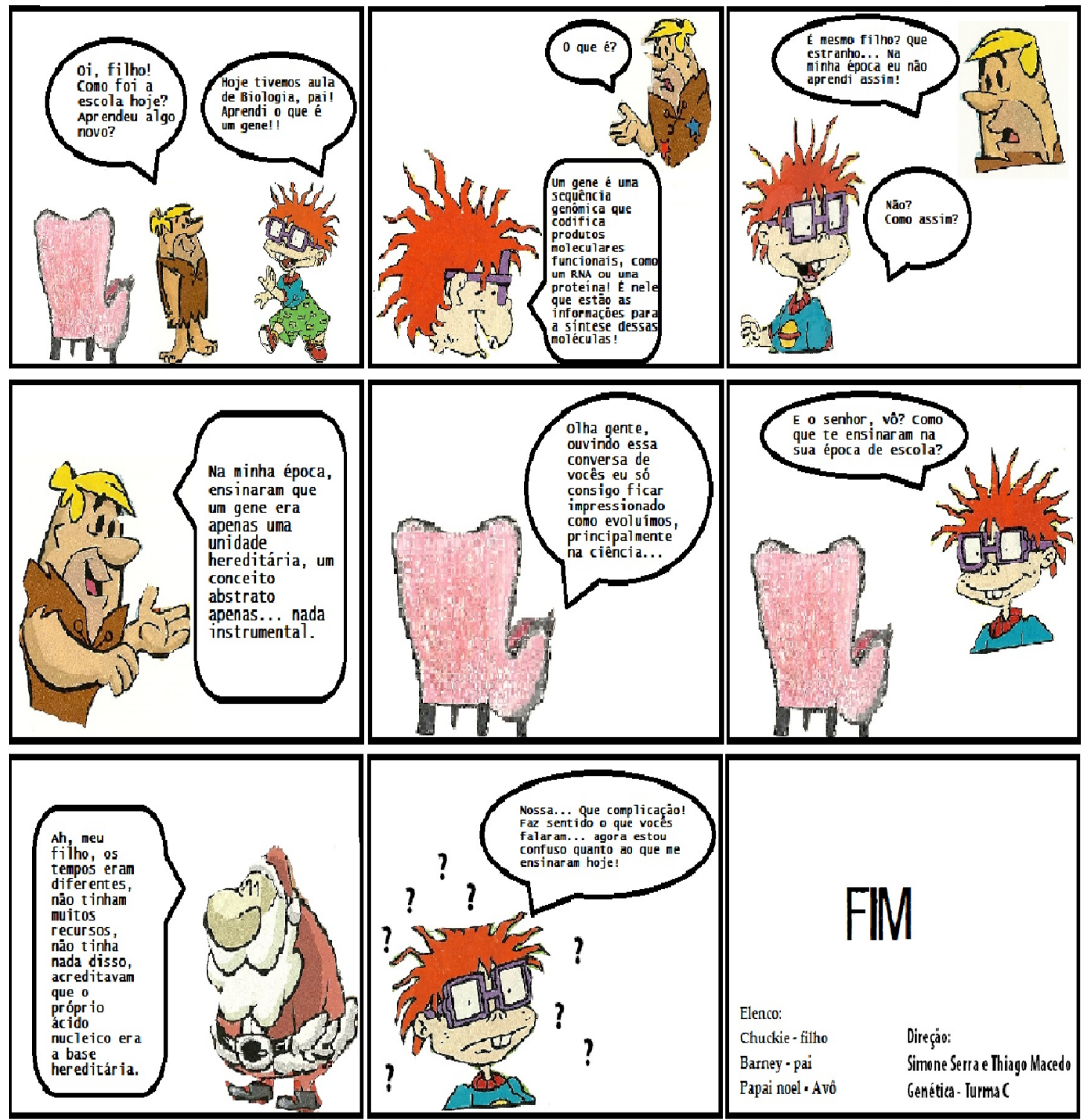

Figura 11 Tirinha 9 desenvolvida por estudantes de Ciências Biológicas e Biotecnologia da Universidade de Brasília, sobre o tema: a crise do conceito de gene. 
Uma comparação com a voz e o texto das atualizações de software presentes em computadores foi utilizada para demonstrar que se deve atualizar o conceito de gene (Figura 12). Já o conceito de gene também pode ser atualizado por meio de uma conversa, como demonstra a tirinha do "porquinho marrento" para a estudante (Figura 13). E em uma rápida conversa com um cientista é demonstrado que o conceito precisa ser repensado (Figura 14).

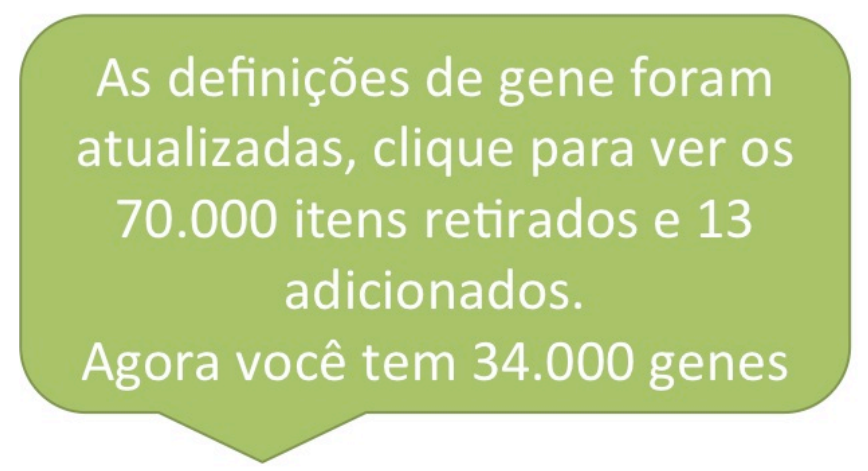

Figura 12 Tirinha 10 desenvolvida por estudantes de Ciências Biológicas e Biotecnologia da Universidade de Brasília, sobre o tema: a crise do conceito de gene.



Figura 13 Tirinha 11 desenvolvida por estudantes de Ciências Biológicas e Biotecnologia da Universidade de Brasília, sobre o tema: a crise do conceito de gene.
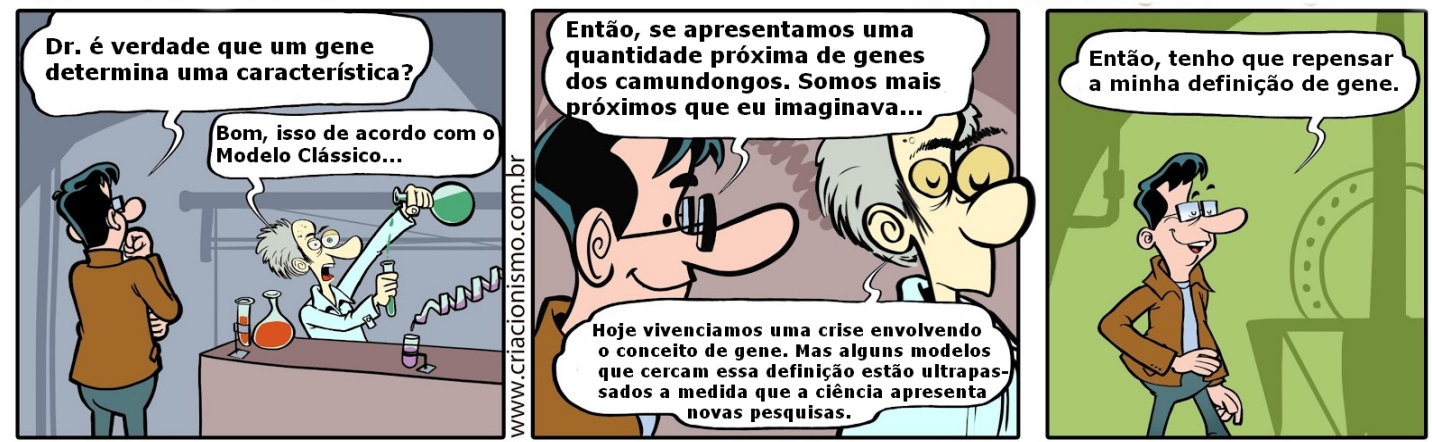

Figura 14 Tirinha 12 desenvolvida por estudantes de Ciências Biológicas e Biotecnologia da Universidade de Brasília, sobre o tema: a crise do conceito de gene. 
Ou então, quando a candidata à presidência Marina Silva surge com uma nova proposta, onde as novidades sobre o conceito do gene foram comparadas a um panorama histórico, econômico, social e cultural (Figura 15). Essa última englobou mais conceitos e o estudante que a apresentou deixou a sensação de que entendeu bem o conteúdo e a dinâmica da crise do conceito do gene.

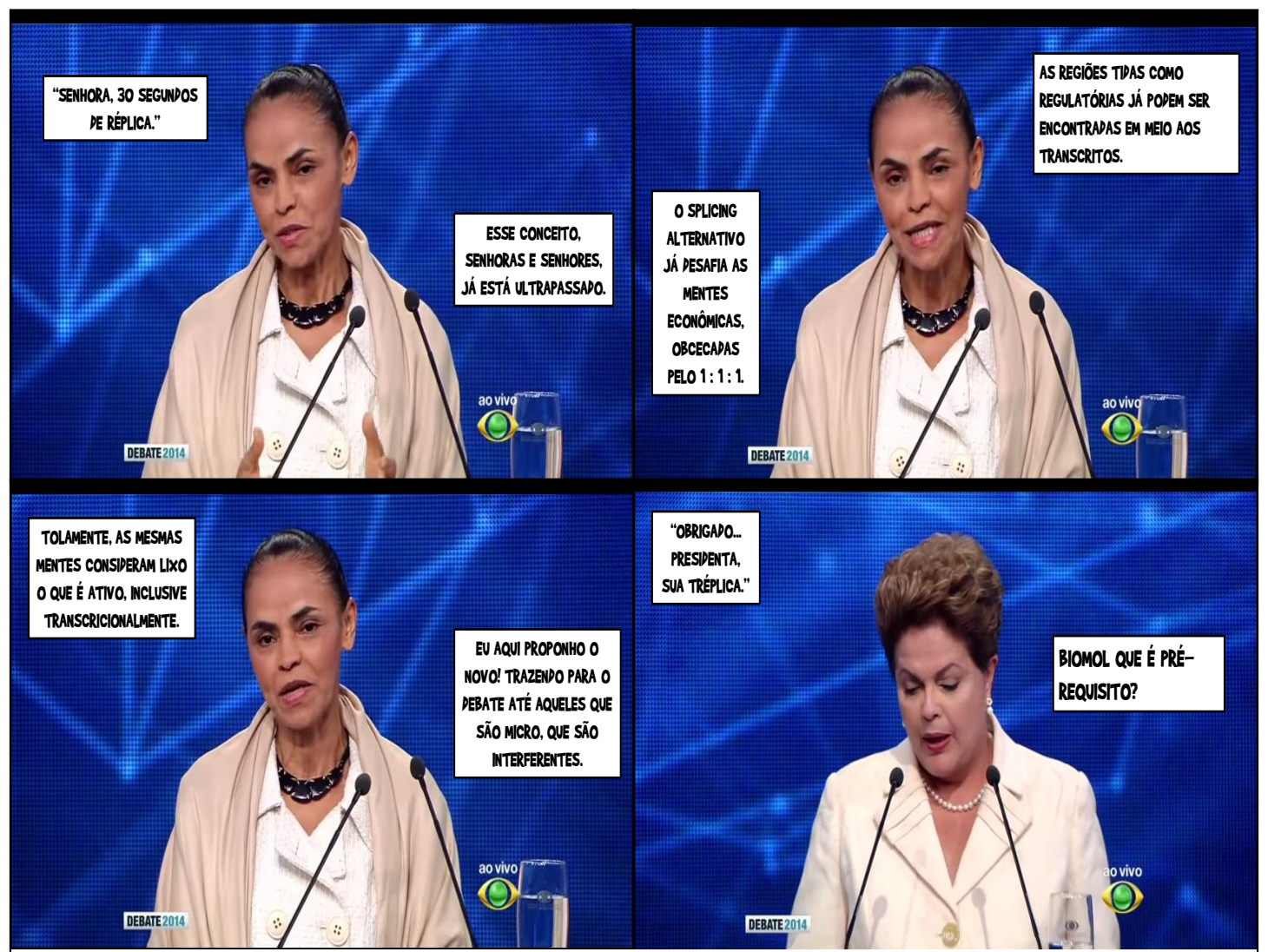

Figura 15 Tirinha 13 desenvolvida por estudantes de Ciências Biológicas e Biotecnologia da Universidade de Brasília, sobre o tema: a crise do conceito de gene.

O abandono do conceito de gene (27) foi assunto de três tirinhas.

Esse abandono foi demonstrado com uma analogia a Plutão, que deixou de ser planeta (Figura 16). Plutão, nesse caso, representa o conceito de gene, enquanto os demais integrantes do sistema solar são conceitos de Genética que ainda são utilizados. Outra forma de demonstrar o abandono foi por meio de um cientista que foge do assunto para não ter que explicar o que é gene (Figura 17), ou por um alienígena que preferiu desistir de dominar a terra a conceituar gene (Figura 18). A ideia, no entanto, não era abandonar o conceito e sim demonstrar que é o momento onde essas novas descobertas devem se fixar no aprendizado 


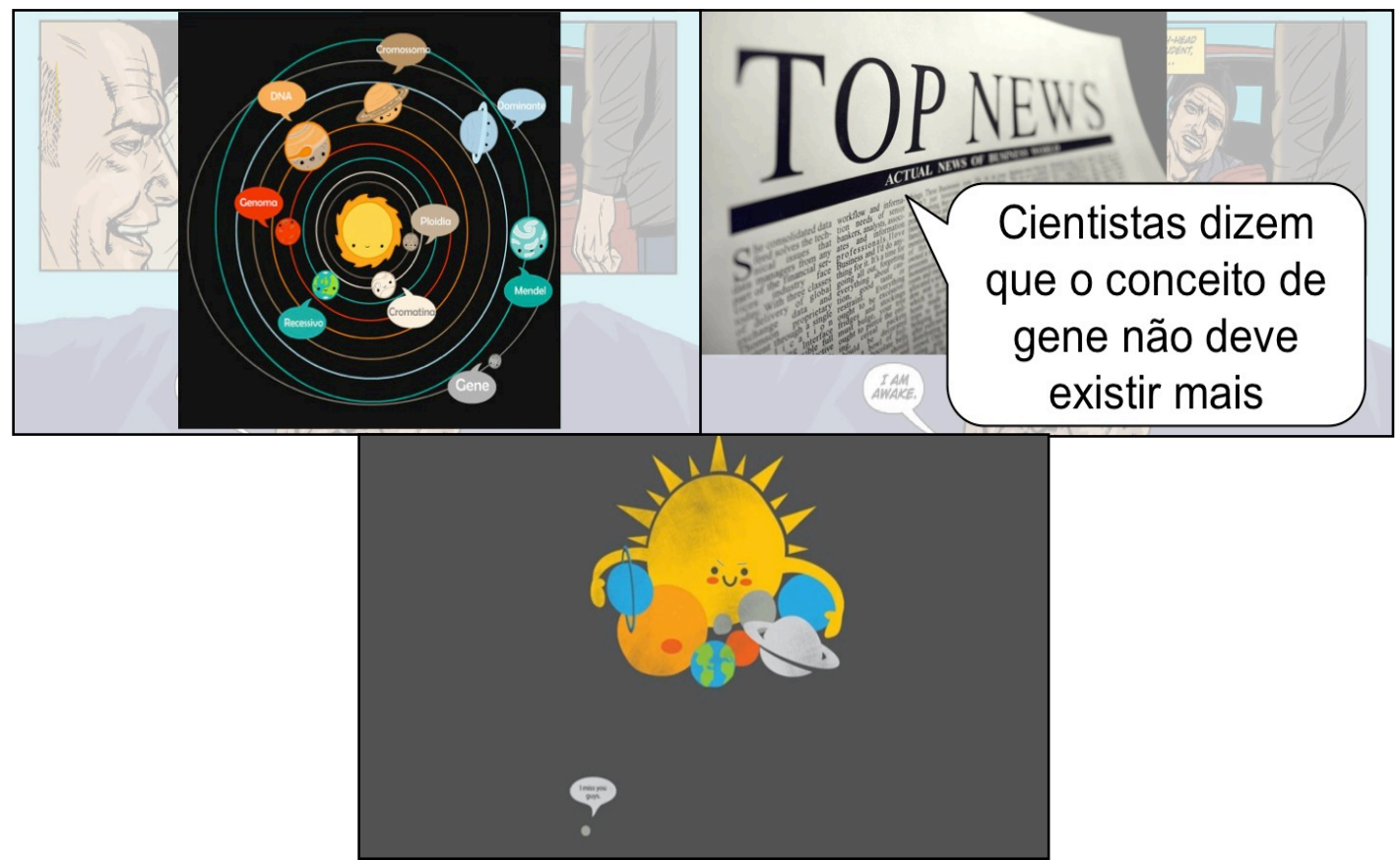

Figura 16 Tirinha 14 desenvolvida por estudantes de Ciências Biológicas e Biotecnologia da Universidade de Brasília, sobre o tema: o abandono do conceito de gene.

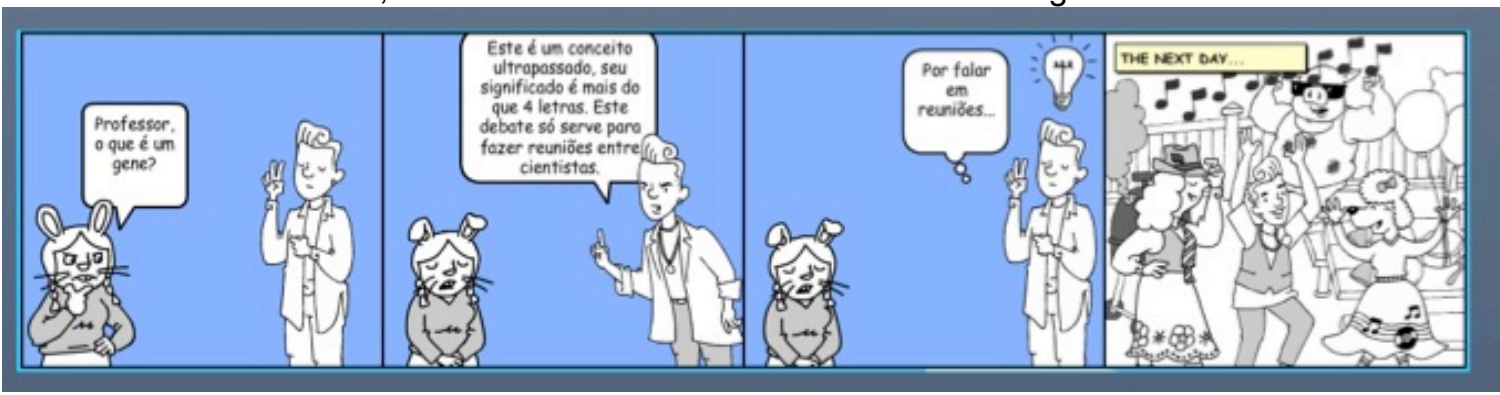

Figura 17 Tirinha 15 desenvolvida por estudantes de Ciências Biológicas e Biotecnologia da Universidade de Brasília, sobre o tema: o abandono do conceito de gene.

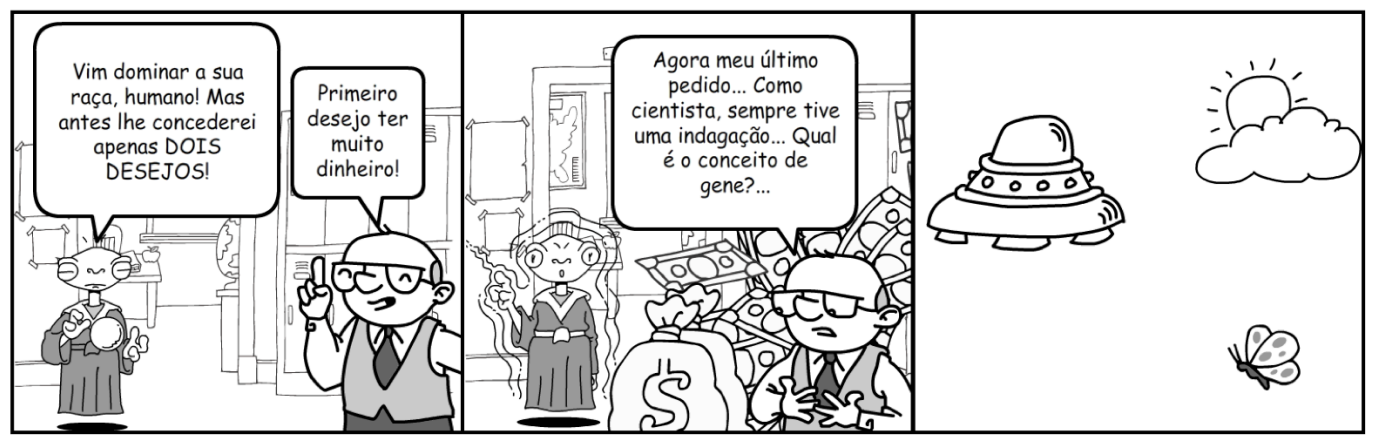

Figura 18 Tirinha 16 desenvolvida por estudantes de Ciências Biológicas e Biotecnologia da Universidade de Brasília, sobre o tema: o abandono do conceito de gene. 
A ideia do conceito de gene como processos (17) foi citada em uma tirinha, onde os cromossomos precisariam de outros incentivos para entender a conversa (Figura 19).

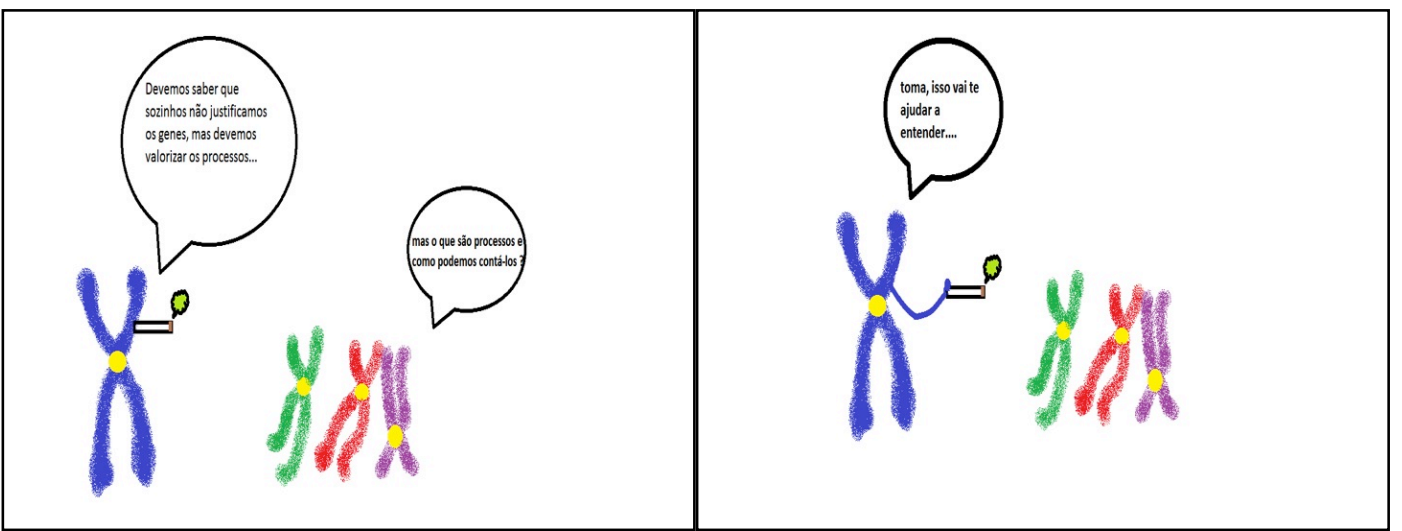

Figura 19 Tirinha 17 desenvolvida por estudantes de Ciências Biológicas e Biotecnologia da Universidade de Brasília, sobre o tema: o conceito de gene como processos.

A fixação desse novo conhecimento pode ser observada na explicação da tirinha do "Calvin" (desenhado por Bill Watterson, 1985), onde os estudantes citaram uma consequência desse conceito "em um ambiente onde o DNA é comandado e não comandante, o conceito de gene só faz sentido dentro de um contexto celular" (Figura 20).
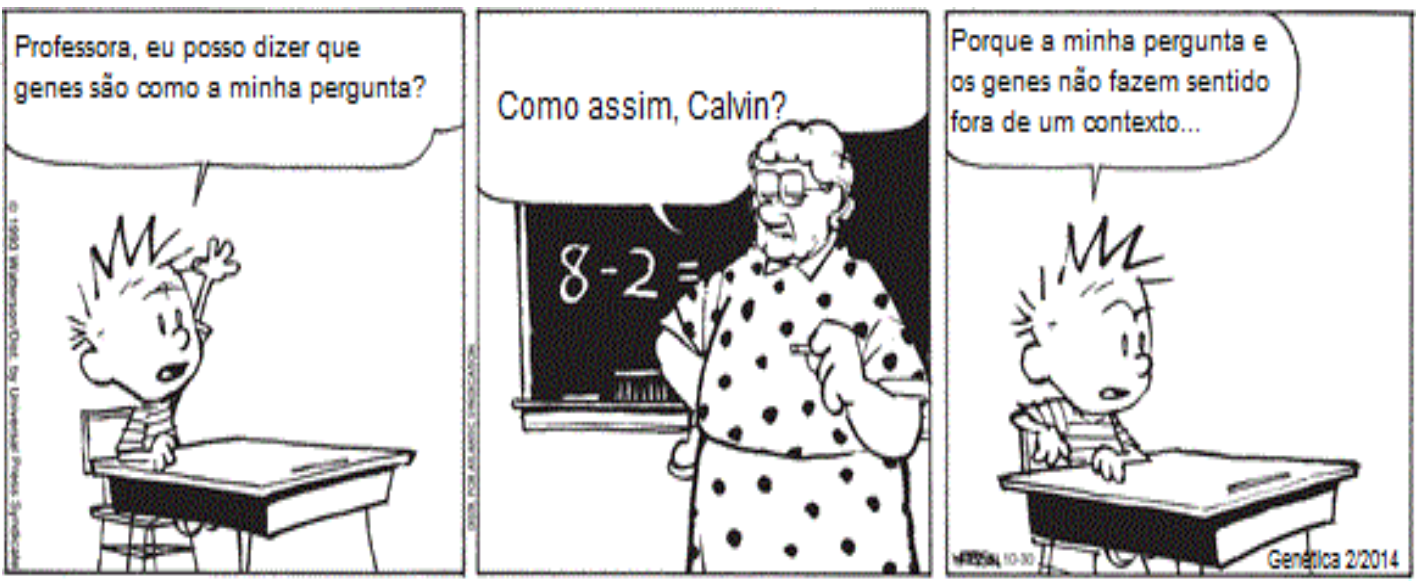

Figura 20 Tirinha 18 desenvolvida por estudantes de Ciências Biológicas e Biotecnologia da Universidade de Brasília, sobre o tema: o conceito de gene como processos.

O conceito de Gene-P e Gene-D $(20,21)$ foi o assunto de duas tirinhas. Em ambas as tirinhas, um estudante se mostra confuso a respeito dos novos conceitos e expõe essas dúvidas para o professor, que direciona o estudante (Figura 21). Na tirinha 20 (Figura 22), o crédito da autoria do Gene-P e -D foi para "Pardini e Guimarães" (29), quando o correto é Moss 
$(20,21)$. A professora corrigiu essa informação para os estudantes na sala de aula.

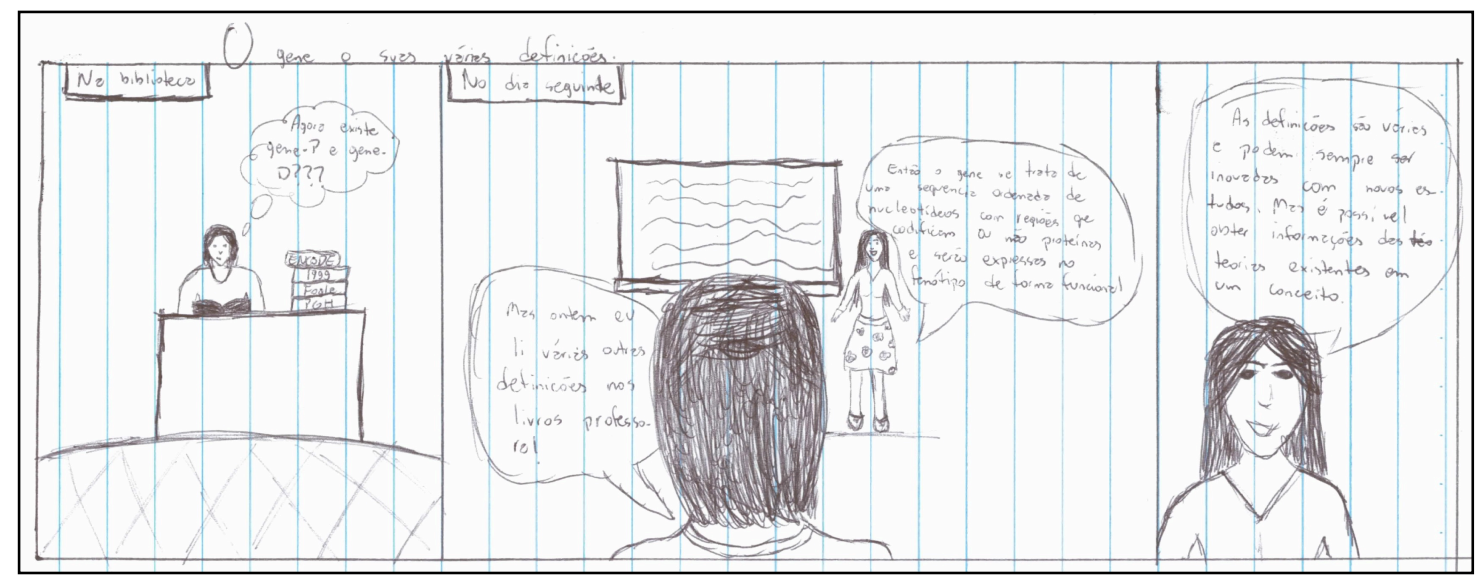

Figura 21 Tirinha 19 desenvolvida por estudantes de Ciências Biológicas e Biotecnologia da Universidade de Brasília, sobre o tema: o conceito de gene-P e gene-D.

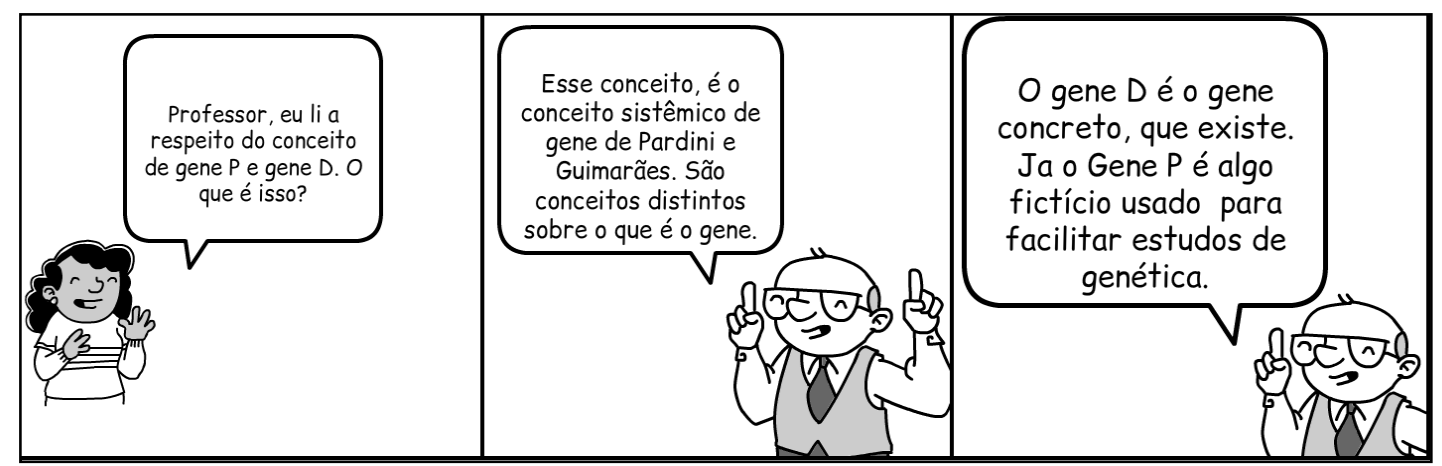

Figura 22 Tirinha 20 desenvolvida por estudantes de Ciências Biológicas e Biotecnologia da Universidade de Brasília, sobre o tema: o conceito de gene-P e gene-D.

Para trabalhar com o conceito de gene definido pelo ENCODE (31, 32), a Enciclopédia de Elemento do DNA se transformou em uma forma de entender as mulheres (Figura 23). A moral de história é que entender mulheres é tão difícil quanto acompanhar os novos conhecimentos sobre o material genético. Já a tirinha sobre genes interrompidos surgiu a partir das diferenças entre procariotos e eucariotos, aparecendo como um evento pós transcricional (Figura 24). Os autores não explicaram que é a presença de núcleo na célula que permite as diferenças no transcrito, então a professora interveio esclarecendo esse ponto. 


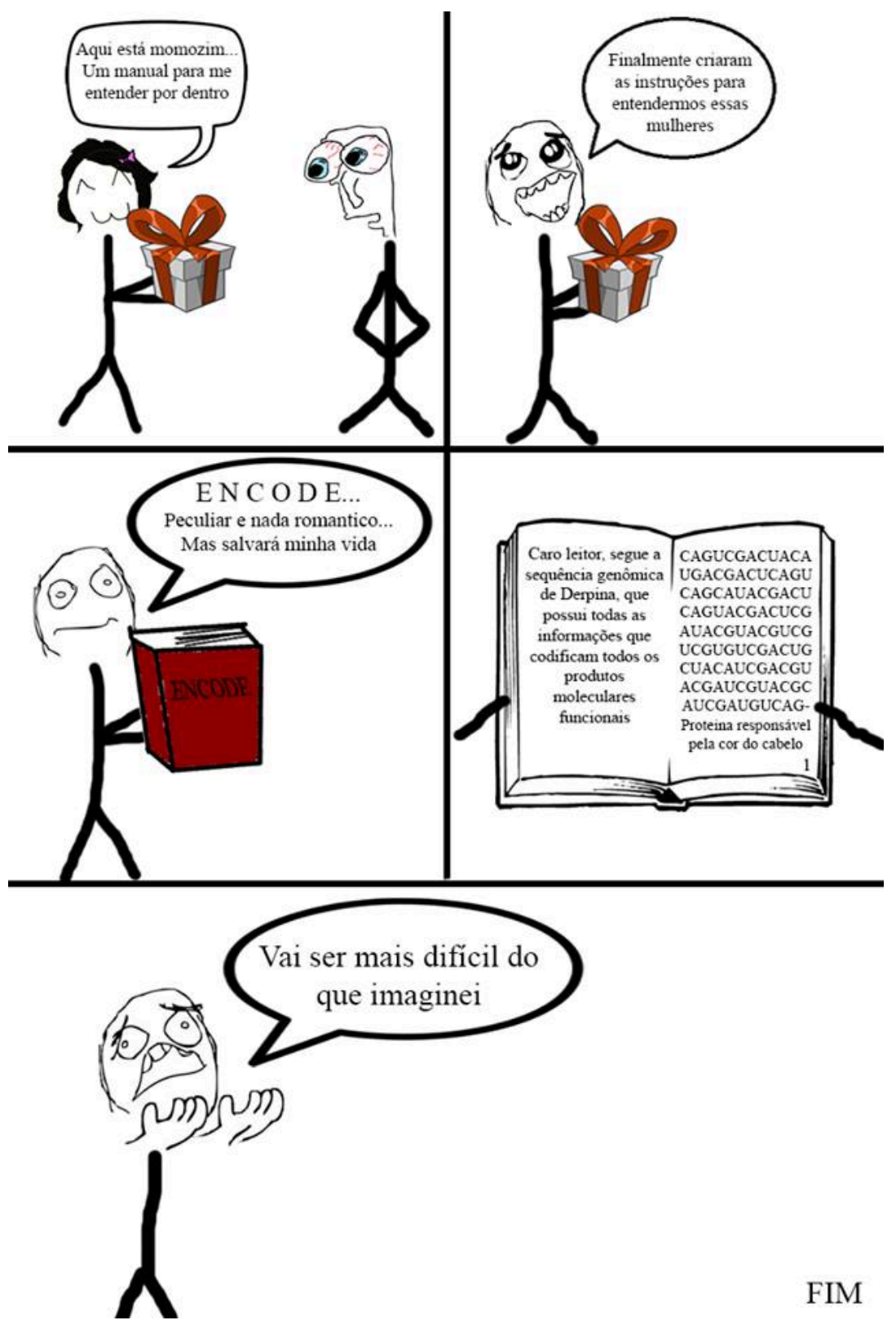

Figura 23 Tirinha 21 desenvolvida por estudantes de Ciências Biológicas e Biotecnologia da Universidade de Brasília, sobre o tema: o conceito de gene definido pelo ENCODE.

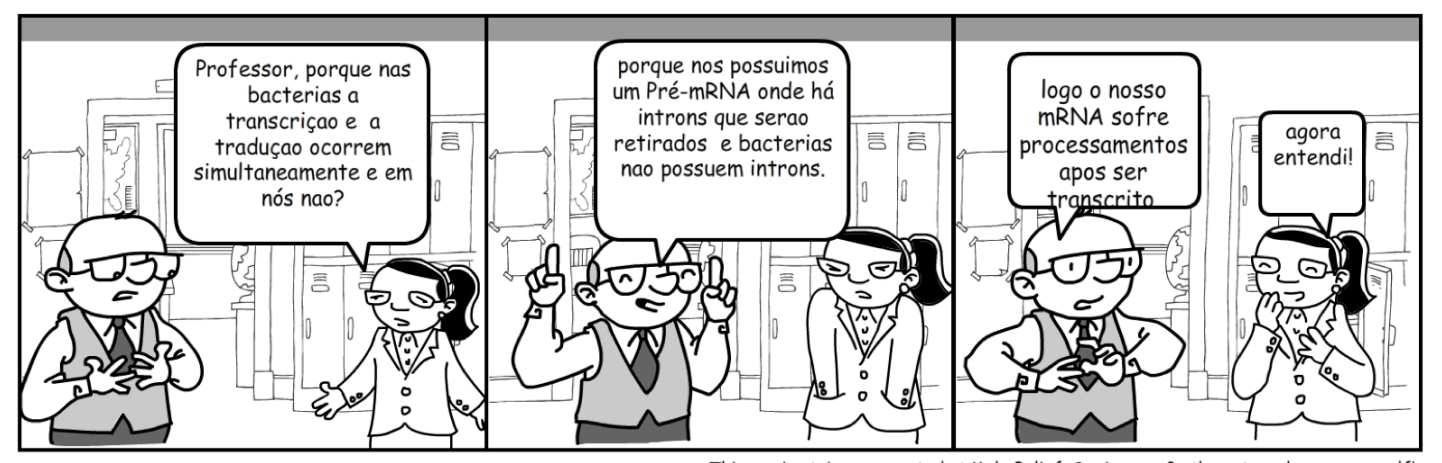

Figura 24 Tirinha 22 desenvolvida por estudantes de Ciências Biológicas e Biotecnologia da Universidade de Brasília, sobre o tema: genes interrompidos. 
Dois grupos trabalharam a herança monogênica por meio de questionamentos sobre as características de um indivíduo. A primeira tirinha acompanhou os seguintes questionamentos: 1. a característica trabalhada (peso e altura) é uma herança monogênica?, 2. é possível deduzir o fenótipo da família?, 3. Qual a dominância "genetípica" (SIC)? e 4. qual a influência do ambiente? (Figura 25). Na segunda tirinha produzida, os estudantes fizeram uma relação errônea entre a cor dos olhos e a herança mendeliana (Figura 26). Os demais estudantes questionaram durante a apresentação de ambas as tirinhas: "O que foi demonstrado é o que realmente acontece?" e "A herança mendeliana realmente explica a cor dos olhos?". A professora direcionou a discussão, mas deixou maiores explicações para serem feitas quando o assunto fosse dado em sala de aula.
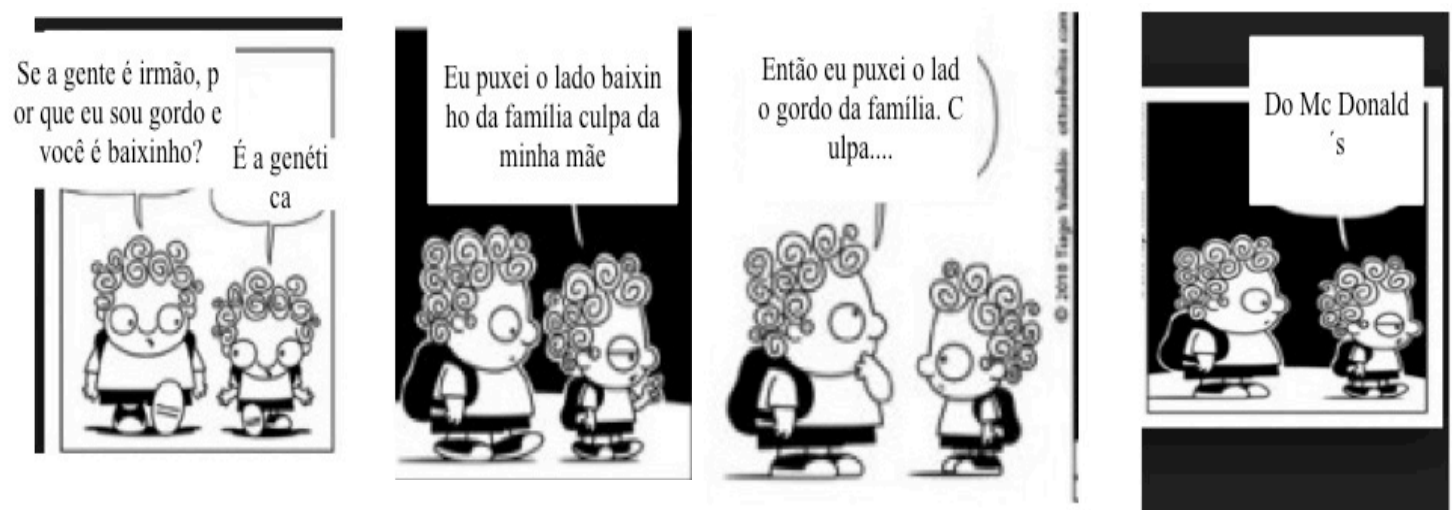

Figura 25 Tirinha 23 desenvolvida por estudantes de Ciências Biológicas e Biotecnologia da Universidade de Brasília, sobre o tema: herança monogênica.



Figura 26 Tirinha 24 desenvolvida por estudantes de Ciências Biológicas e Biotecnologia da Universidade de Brasília, sobre o tema: herança monogênica. 
O determinismo genético foi apresentado em três tirinhas. Em uma das tirinha uma hemácia normal conversa com uma hemácia falcêmica que culpa a Genética por ser diferente (Figura 27). A segunda tratou o tema de forma proposital, para ir contra ao determinismo genético, questionando de onde vem às diferenças, se são por meio da interação gênica ou do meio ambiente (Figura 28). A terceira tirinha foi desenhada com personagens dos "Os Simpsons" (desenhado por Matt Groening, 1989) e a preguiça do Homer foi explicada "geneticamente" (Figura 29). Aqui fica o questionamento dos estudantes de que "os genes definem características fenotípicas e comportamentais?". Por meio dessas tirinhas os estudantes quiseram questionar o determinismo genético estimulando a discussão.

Por fim, a tirinha com o tema fenótipo vem com uma proposta de discussão, pois os autores acreditam que existem dúvidas acerca desse assunto: "as pessoas não sabem o que é o conceito de fenótipo". E ao longo da apresentação mostram que a interação do meio ambiente com o fenótipo pode mudar e finalizam conceituando fenótipo como "as características morfológicas expressas" (Figura 30).

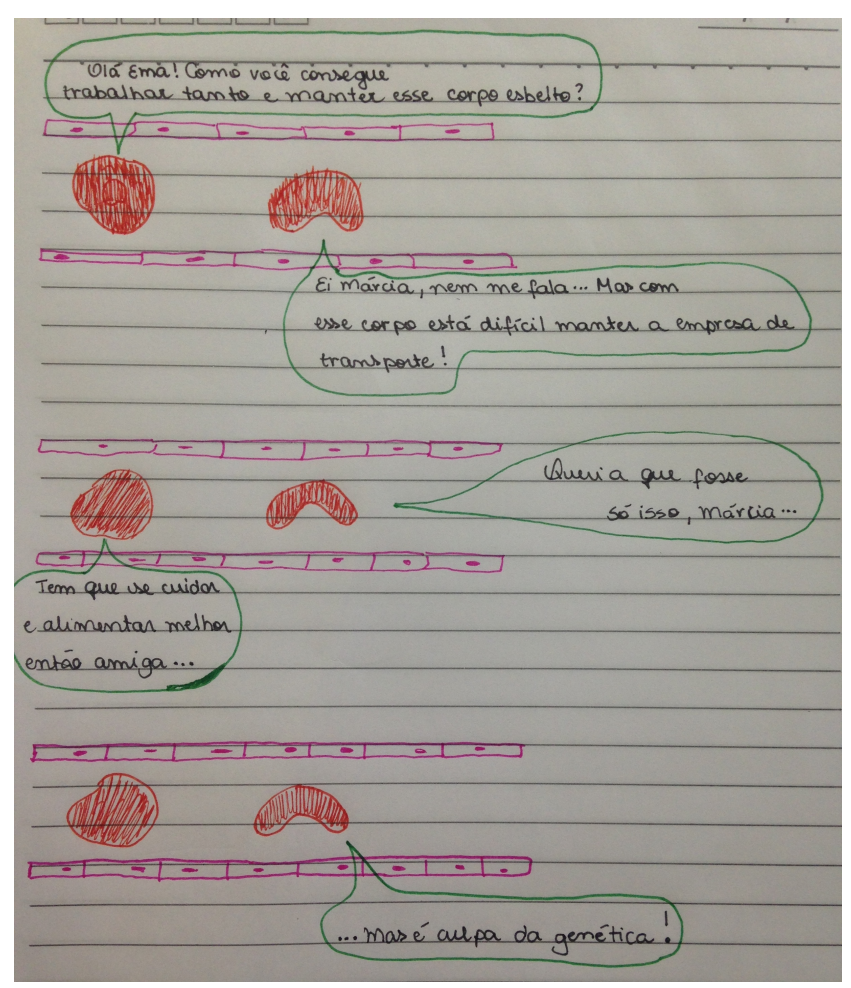

Figura 27 Tirinha 25 desenvolvida por estudantes de Ciências Biológicas e Biotecnologia da Universidade de Brasília, sobre o tema: determinismo genético. 




Figura 28 Tirinha 26 desenvolvida por estudantes de Ciências Biológicas e Biotecnologia da Universidade de Brasília, sobre o tema: determinismo genético.



Figura 29 Tirinha 27 desenvolvida por estudantes de Ciências Biológicas e Biotecnologia da Universidade de Brasília, sobre o tema: determinismo genético.

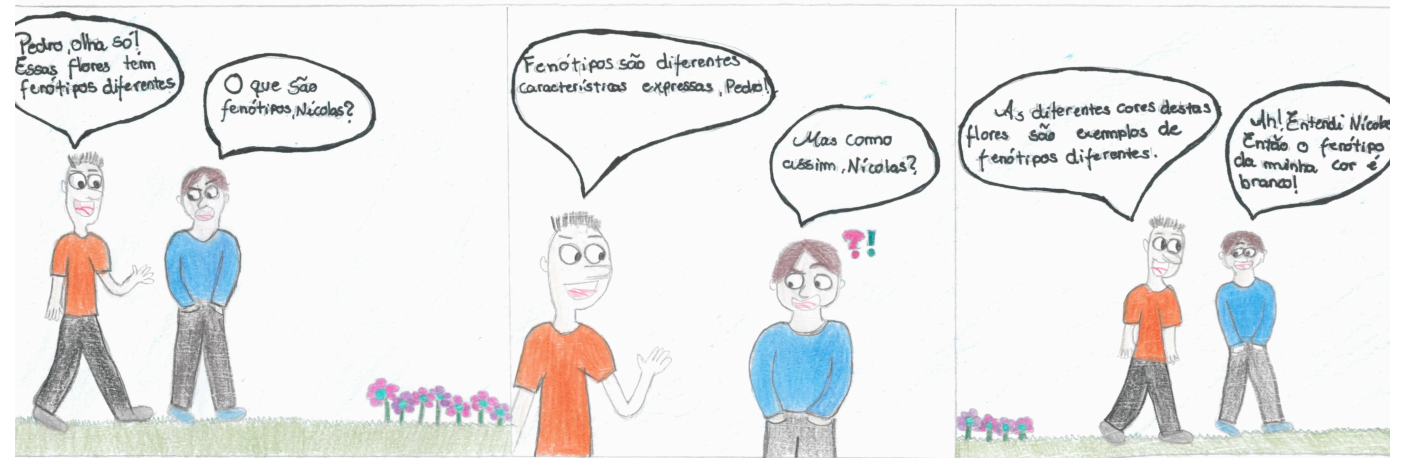

Figura 30 Tirinha 28 desenvolvida por estudantes de Ciências Biológicas e Biotecnologia da Universidade de Brasília, sobre o tema: determinismo genético. 


\subsection{AVALIAÇÃO DO PROCESSO DE ENSINO E APRENDIZAGEM DAS PROPOSTAS POR MEIO DE QUESTIONÁRIO}

A parte 1 do questionário buscou avaliar as tirinhas. Na questão 1, $35,7 \%$ dos estudantes concordaram que as tirinhas ajudaram muito a terem mais questionamentos e participações ao longo da disciplina. No entanto, a maioria $(47,6 \%)$ considerou essa ajuda moderada, enquanto $7,1 \%$ considerou que o material desenvolvido ajudou pouco. Apenas 2,4\% classificaram as tirinhas como nada eficiente nesse quesito. Na questão 2, 52,4\% dos estudantes concordam que as tirinhas desenvolvidas contribuíram para rever os conceitos. Contudo, 9,5\% acreditam que as tirinhas não contribuíram nada. A porcentagem dos estudantes que não puderam avaliar essa parte do questionário se justificou pelo fato de não terem feito a sequência completa. Esses dados estão representados na Figura 31 (a).

A questão de resposta aberta, contida na parte 1 do questionário, sobre a abordagem do tema por meio das tirinhas, revelou que $90 \%$ das respostas foram relatando o quanto os estudantes gostaram da abordagem com comentários como: "inovadora", "criativa", "interessante", "descontraída", "didática", "reflexiva", "lúdica". Aproximadamente 65\% deles relataram nesse espaço que as tirinhas ajudaram a "compreender", "refletir", a "aprender melhor", e ainda, que "estimulou a construção de conceitos", "motivou um olhar mais crítico" e "esclareceu o que leem nos livros". Alguns aproveitaram o espaço para tecer elogios ao material como pode-se ler em "Tirinha são sempre sensacionais", "Retoma o prazer de ler histórias em quadrinhos" e "Apoio o uso de diferentes linguagens para o incentivo do pensamento critico". Uma porcentagem de $11 \%$ desaprovaram a utilização do material com argumentações como "superficial", "infantil", "desnecessária", "bom para distrair", "nada relevante", "pouco eficiente".

A parte 2 do questionário foi voltada para análise da construção do conceito do gene, mais especificamente as aulas teóricas e os textos. $\mathrm{Na}$ questão 3,73,8\% dos estudantes concordaram que a utilização dos textos facilitou muito o entendimento sobre $o$ atual desenvolvimento científico a respeito do tema trabalhado. No mesmo sentido mais de $25 \%$ acreditam que 
os textos ajudaram moderadamente. Apenas 4,8\% acham que os textos não facilitaram o entendimento. Nenhum estudante avaliou esse quesito como nada eficiente ou não pode avaliar. Na questão 4 a maioria dos estudantes $(57,4 \%)$ avaliaram que as aulas teóricas contribuíram muito para o entendimento do assunto, bem como $26,2 \%$ marcaram a opção moderadamente. Por fim, 2,4\% julgaram que aulas foram pouco eficientes, enquanto 4,8\% não conseguiram avaliar. Esses resultados se encontram na Figura 31 (b).

A maioria dos comentários a respeito da parte 2 foram positivos e agregou cerca de $33 \%$ dos estudantes. Exemplo de comentários são: "adorei", "ajudou nos estudos", "didático e autoexplicativo" e "os textos ajudaram muito no aprendizado". Por outro lado, 5,7\% criticaram o trabalho com as seguintes opiniões: "os conceitos diferentes causaram confusão" e "aulas curtas". Uma frase chamou a atenção por transcrever exatamente a impressão deixada em sala de aula: "As aulas bagunçaram o entendimento momentaneamente até a leitura dos textos e discussão".

A parte 3 do questionário analisou a construção do conceito do gene e seus resultados se encontram na Figura 31 (c). Na questão 5, 47,6\% dos estudantes consideraram a retomada da tirinha eficiente para construir o conceito de gene. Não obstante, $26,2 \%$ classificaram a retomada da tirinha inicial com moderadamente eficiente. É nesta questão que se tem a maior porcentagem que concordam pouco com alguma parte da sequência didática, totalizando $21,4 \%$. Apenas $4,8 \%$ acreditam que a retomada não foi eficiente na construção. Na questão 6 a maioria dos estudantes $(57,1 \%)$ concordam que a demonstração de novos pontos de vista e questionamentos ajudaram a reconstrução do conceito. Fato que soma-se aos $31 \%$ que concordaram moderadamente. Porém, $11,9 \%$ avaliaram que pouco se acrescentou. Nenhum estudante se sentiu incapaz de avaliar as duas questões.

A parte 3 também contou com uma questão de resposta aberta. $73 \%$ dos estudantes avaliaram positivamente as suas respostas após a reconstrução do conceito de gene: "mais completas", "com mais questionamentos", "mais clara”, "mais objetiva”, "melhor que primeira”, "mais embasada", "mais explicada", "ampliou os conhecimentos" e "mais pragmática". Um estudante definiu a sua avaliação com a sentença de que 
"Agora entendo que gene não é apenas 'uma sequência de DNA que pode ser transcrito em um mRNA". Enquanto 11,9\% avaliaram negativamente as respostas ou a atividade: "não achou necessário", "preguiça de reescrever", "não foi eficiente", "pouco acrescentou", "não atribui melhora devido às tirinhas".

$\mathrm{Na}$ parte 4 foi avaliada a elaboração das tirinhas pelos estudantes. $\mathrm{Na}$ questão 7 apenas 19\% dos estudantes acharam a dinâmica muito eficiente para trabalhar os novos conhecimentos adquiridos, enquanto $57,1 \%$ dos estudantes avaliaram a eficácia como moderada. A opinião de 11,9\% é de que a elaboração foi pouco eficiente e de 9,5\% que foi nada eficiente. Uma porcentagem de 2,4\% não puderam avaliar a questão. Na questão 8, 35,7\% dos estudantes concordaram que a atividade estimulou muito a discussão e pensamento critico. Uma porcentagem um pouco acima $(38,1 \%)$ avaliou moderadamente. No entando,19\% concluíram que a elaboração das tirinhas foi nada estimulante para a discussão. Apenas 2,4\% não conseguiram avaliar essa questão. Esses resultados se encontram na Figura 31 (d).

No espaço reservado para comentários, $26,1 \%$ dos estudantes explanaram a concordância com a atividade: "legal”, "gostei muito", "desperta a criatividade", "aumenta o conhecimento", "produção do texto pelos alunos", "permitiu discussão", "emite opinião sobre o tema", "atividade inovadora", "bacana", "estimula crítica e avaliações". Enquanto 30\% aproveitaram o espaço para relatar as maiores dificuldades encontradas na elaboração, como "a tirinha tem um espaço muito curto para transmitir toda a informação necessária", "dificuldade em tratar o tema com criatividade sem um domínio sólido sobre o tema", "timidez para apresentação perante a turma", "preocupação com humor e ironia", "preocupação em ser engraçado", "o modo em como a atividade foi exposta causou dúvidas na sua execução", "maior preocupação com a estética da tirinhas do que com o conhecimento" e "É mais fácil comentá-las do que produzi-las".

Na parte 5 houve a avaliação de toda a sequencia didática. Na questão $\mathbf{9}$, $35,7 \%$ dos estudantes avaliaram que a estratégia despertou muito interesse sobre o tema trabalhado. A maioria (59,5\%) acredita que a estratégia despertou um interesse moderado a respeito do tema. No entanto, $4,8 \%$ concordam que a estratégia didática proposta não despertou nenhum interesse a respeito do tema. 
Na questão 10,33,3\% concordam que a estratégia estimulou a discussão e o pensamento critico. Enquanto quase a metade dos estudantes acreditam que o estimulo foi moderado. Por fim, $21,4 \%$ acreditam que a estratégia não estimulou as características citadas. Esses resultados se encontram na Figura 31 (e).

De uma forma geral, $78,5 \%$ dos estudantes escreveram que os aspectos positivos da sequência didática apresentada foram que ela estimula "a criatividade", "a discussão de um tema científico", "imaginação" e "facilita o aprendizado" por meio de uma "atividade motivadora", da "apresentação de novos métodos de ensino", e de "bons textos". As atividades ainda propõem "novos desafios", "leitura diferente" e é "esclarecedor", "inovador", promovendo o "pensamento critico", reforçando a "intertextualidade" e a "capacidade comunicativa do aluno". É interessante registrar a frase elaborada por um estudante: "A discussão por etapas facilita o engajamento no assunto".

No campo dos aspectos negativos $19 \%$ das respostas descrevem os obstáculos encontrados: "elaborar apenas uma tirinha é pouco", "existência de diversos conceitos confundem", "as vezes é difícil de acompanhar e levar o raciocínio a frente". Termos como "infantil", "parece ensino fundamental", "desnecessário" foram citados por $11 \%$ dos estudantes.

Nas sugestões, 4,7\% das respostas pediram para utilizar outros meios de divulgação para avaliar a terminologia, enquanto $2,3 \%$ propuseram sugerir a didática para outros professores. 


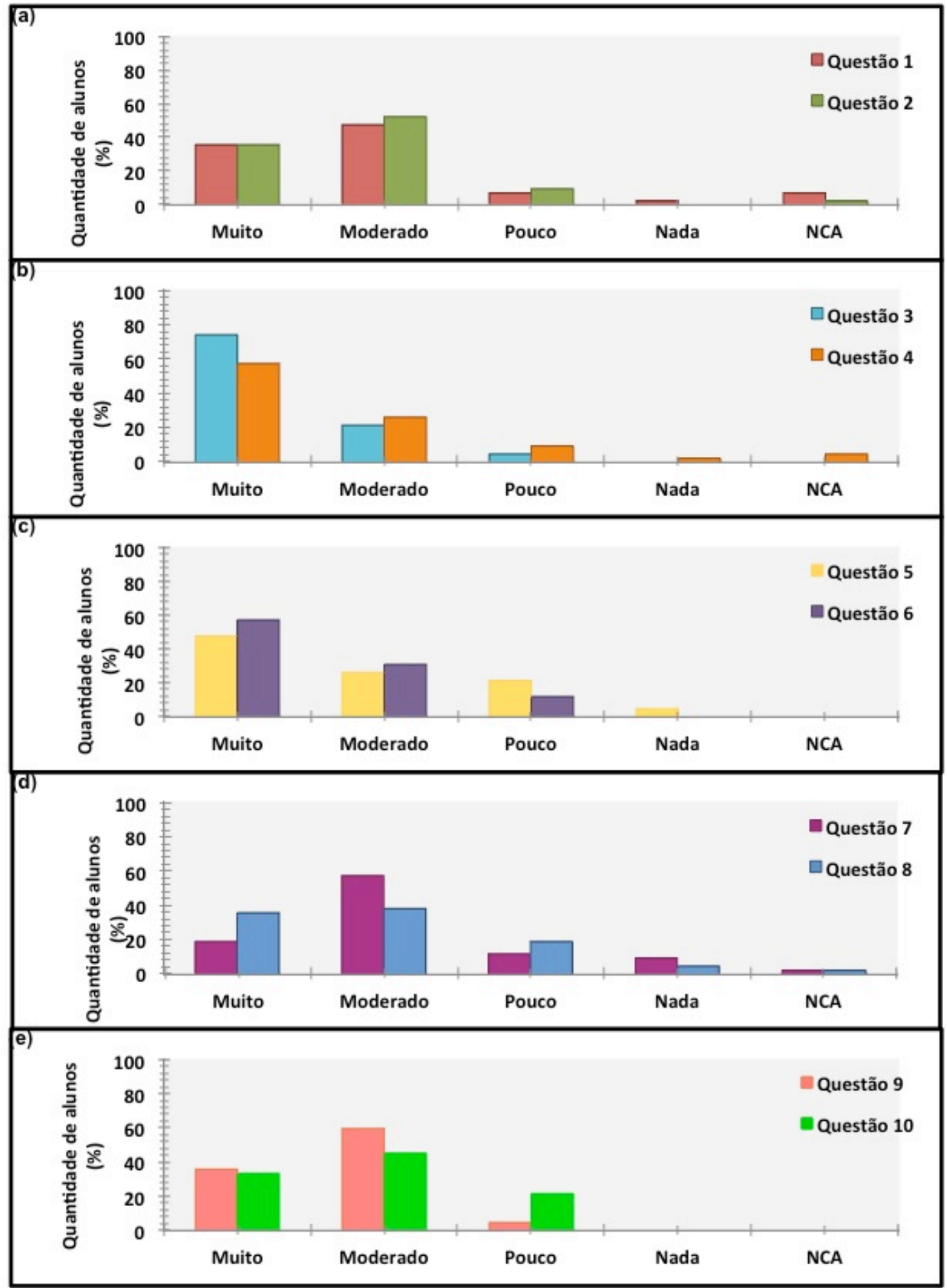

Figura 31 Resultados da avaliação das atividades pelos estudantes de Ciências Biológicas e Biotecnologia $(n=48)$, por meio do questionário desenvolvido. Os graus de concordância atribuídos às respostas foram muito, moderado, pouco, nada e não consigo avaliar (NCA). $O$ primeiro resultado se refere (a) à avaliação do material didático, o segundo (b) a analise das aulas teóricas e textos utilizados para a reconstrução do conceito de gene, o terceiro (c) à retomada da tirinha inicial para a reconstrução do conceito de gene, o quarto (d) à elaboração de tirinhas autorais pelos estudantes, e o quinto (e) a toda sequência didática. 


\section{DISCUSSÃO}

\subsection{AVALIAÇÃO DOS CONHECIMENTOS PRÉVIOS SOBRE CONCEITO, ESTRUTURA E FUNÇÃO DO GENE}

As tirinhas "Palestra" e "Genética no bar" revelaram que a maioria dos estudantes não faz a relação direta entre um gene: um produto funcional: uma função, pois o conhecimento prévio sobre o Dogma Central da Biologia Molecular, a redundância do código genético e o conceito molecular clássico de gene está presente para a maioria dos estudantes dos cursos de Ciências Biológicas e Biotecnologia. Alguns fatores conhecidos contribuem para esse resultado. No currículo vigente da Universidade de Brasília, os cursos Ciências Biológicas e Biotecnologia cursam a disciplina de "Biologia Molecular" um semestre antes da disciplina de Genética, permitindo que esses estudantes sejam capazes de mobilizar esse conhecimento para negar a relação direta.

Quando esses resultados foram comparados com o observado no curso de Enfermagem, notou-se que maioria desses últimos ainda faz as relações diretas. Isso pode ser atribuído ao fato de que são recémingressados na universidade, cursando a disciplina de Genética no primeiro semestre. Todavia, esses resultados devem refletir com maior fidelidade a compreensão dos conceitos a partir de informações obtidas no ensino médio e são consequências das dificuldades do ensino de genética tradicional centradas no excesso de vocabulário exclusivo e alto grau de abstração. No entanto, em todos os cursos foram identificados erros conceituais ou confusões do conteúdo, tais como: "genes codificam aminoácidos", "os aminoácidos agrupados formam códons", "os aminoácidos estão ligados às proteínas que os genes carregam", "os aminoácidos fazem parte da composição do gene", "genes são constituídos de proteínas" e "o nosso código genético possuem regiões denominadas íntrons e éxons". Já o pensamento crítico e reflexivo foi apreendido em algumas respostas que mostraram interação com o material, como: "Que burro!"; bem como em 
respostas com ideias de fuga ao gene-centrismo, como: "não seria um gene que metabolizaria a cerveja".

Na tirinha "Estudando para a prova", o conhecimento do modelo bioquímico-clássico, onde o gene se encontra no cromossomo e é uma unidade de transmissão e função, predominou nas respostas do curso de Ciências Biológicas. O modelo mendeliano de gene, onde o gene é uma unidade de transmissão e função, foi o mais popular nas respostas dos estudantes de Enfermagem e Biotecnologia. Já o conceito molecular clássico do gene, onde o gene tem localização fixa no cromossomo, que não tem interrupções e desempenha uma função única, foi observado para cerca de $51 \%$ dos estudantes de Biotecnologia, 34\% dos de Ciências Biológicas e para $11 \%$ dos de Enfermagem. Esses dados demonstram a carência de compreensão do gene como um conceito moderno pela maioria dos estudantes, mesmo quando já foram cursadas disciplinas que poderiam auxiliar na construção desse conhecimento.

Dentro destes conhecimentos, não existe clareza sobre quais produtos funcionais são originados, e quando citados há predominância da "proteína" e omissão do "RNA". Nota-se, ainda, a prevalência de ideias errôneas e confusas de que gene é "genótipo", "uma sequência de aminoácido", "cromossomo", "o princípio da divisão celular".

Uma das causas dessas dificuldades é que o ensinamento da genética é fragmentado, demonstrando o quanto é difícil para os estudantes estabelecerem conexões entre os níveis moleculares e celulares, quando enfrentam situações que exijam esses conhecimentos. Concepções semelhantes são encontradas nos conhecimentos prévios dos estudantes analisados no trabalho de Boujemaa et al. (6). Esse trabalho conclui que os estudantes possuem dificuldades em definir corretamente o que é gene, relacionar conceitos em genética e, ainda, apresentam concepções sobre genética que diferem do modelo científico atual, mesmo depois de receber conhecimentos em Genética no ensino médio e superior. 


\subsection{PROPOSTA METODOLÓGICA DE USO DAS TIRINHAS NO ENSINO SUPERIOR}

Os dados relacionados aos Textos 1 e 2 demonstraram que os estudantes obtiveram uma boa visualização dos mapas conceituais, das novas propostas de conceitos de gene apresentados e a preferencia pela definição do conceito de gene do ENCODE, que define o gene como uma união de sequências genômicas que codificam um conjunto de produtos funcionais potencialmente sobrepostos. $O$ uso de mapas conceituais para gerar ideias sobre o conceito de gene e compará-los com modelos históricos citados na literatura, permite que os estudantes identifiquem as fraquezas de cada modelo e os auxiliam a descobrir os obstáculos encontrados nos mesmos (6).

As respostas analisadas para as tirinhas "Palestra" e "Genética no bar" demonstraram que os desafios em questão têm consequência relativas a ausência da relação 1:1:1 entre gene, sequência de DNA e produto gênico, visto que após a sequência das aulas e dos textos, esses estudantes foram capazes de reformular respostas mais elaboradas, com o acréscimo de diversos fenômenos que reforçam essa afirmação. Esses acréscimos de conteúdo devem-se à presença dos seguintes fenômenos, antes não conhecidos por parte dos estudantes: excisão de íntrons, splicing alternativo, splicing de proteína, trans-splicing de RNA, função regulatória, modificações pós-traducionais, edição de RNA, efeitos pós-transcricionais e genes com quadro de leitura sobrepostas, pseudogenes dentre outros.

Foi observado que $10 \%$ de estudantes reescreveram as respostas dos conhecimentos prévios na fase de reconstrução ou que continuaram entendendo que existe a relação direta, sem agregar os conhecimentos apresentados na sequência. Estes foram considerados como sem aprendizado por terem se confundido ou por não terem feito a dinâmica adequadamente.

Na tirinha "Estudando para a prova", o conceito molecular de gene foi o conceito mais aceito após a reconstrução do conceito, indicando que a sequência didática apresentada rebuscou o conceito pré-existente, além de 
sedimentar uma concepção informacional de gene. Da mesma forma, outros trabalhos apresentam achados semelhantes relativos à visão de gene predominante nos estudantes $(8,45)$. No entanto, essas concepções devem ser analisadas com cautela, uma vez que o modelo molecular clássico de gene não inclui os desafios implementados pelos avanços do conhecimento sobre a crise do conceito de gene (8). Para tanto, este estudo demonstra que, após a sequência didática apresentada aos estudantes, cerca de 17,5\% dos estudantes não acrescentaram a crise ao seu conceito. De uma forma geral, os estudantes envolvidos nessa discussão saíram de uma gradação de ausência de conceito ou presença do conceito mendeliano para o conceito molecular clássico com inclusões de ideias sobre a crise complementando a resposta, fato considerado como um resultado positivo em relação a sequencia didática apresentada.

Outro fator positivo e relevante para essa sequência didática foram os estudantes que se identificaram com as novas visões do conceito de gene, que receberam as informações com pensamentos críticos e reflexivos. Concepções semelhantes foram encontradas no trabalho de Nascimento (8).

\subsection{ELABORAÇÃO E AVALIAÇÃO DE TIRINHAS AUTORAIS}

No início das apresentações os estudantes estavam se sentindo envergonhados para apresentar suas tirinhas perante a turma, alegando insegurança sobre o que desenvolveram e sobre o que iriam falar. Conforme as apresentações foram acontecendo eles foram se sentindo cada vez mais confortáveis para apresentá-las, bem como participar da atividade interagindo com a apresentação dos outros colegas.

Em algumas apresentações os estudantes se mostraram confusos a respeito dos novos conhecimentos adquiridos ou cometeram erros conceituais explicando a sua tirinha. Houveram ainda aqueles que não levaram a atividade a sério. Porém, a maioria dos estudantes foram dedicados ao fazer o trabalho como fora pedido. E, ao final da atividade, esses estudantes estavam satisfeitos com o resultado. 
Esta atividade exigiu disciplina e dedicação por parte dos estudantes para ser bem executada, o que abriu espaço para inúmeras dúvidas e inseguranças durante o processo de decisão do tema a ser abordado. Uma sugestão para suprir essa necessidade seria redirecionar uma parte de uma aula para orientar melhor os estudantes quanto à tomada de decisão do tema e como abordar o assunto, deixando o desenvolvimento da tirinha como trabalho extra classe. Levar os estudantes a encararem as suas concepções os habilitam a adquirir competência para possuir uma visão crítica sobre os conceitos científicos e como eles foram construídos (6).

\subsection{AVALIAÇÃO DO PROCESSO DE ENSINO E APRENDIZAGEM DAS PROPOSTAS POR MEIO DE QUESTIONÁRIO}

A avaliação do material desenvolvido, as tirinhas, foi considerada como um método inovador e criativo pela maioria dos estudantes, e ainda ajudou a compreender e motivar um pensamento crítico na abordagem do tema desenvolvido.

Quanto às aulas teóricas e os textos utilizados como complementação ao ensino da evolução do conceito de gene, os estudantes concordaram que facilitaram muito o entendimento sobre o atual desenvolvimento científico a respeito desse tema. Essa aceitação é descrita no trabalho de Boujemaa et al. (6), que sugere que a utilização de materiais menos tradicionais como abordagens históricas, relacionando as dificuldades metodológicas com os conhecimentos atuais pode facilitar a compreensão dos conceitos de Genética.

A retomada das tirinhas para construir o conhecimento baseado no conhecimento prévio foi considerada eficiente pela maior parte dos estudantes que julgaram ter respostas mais completas após as atividades. Já a elaboração de tirinhas despertou a criatividade dos estudantes para trabalhar os novos conhecimentos adquiridos e ainda estimulou muito a discussão sobre o tema.

Por fim, a aplicação da sequência didática como estratégia para abordar o conceito, estrutura e função de gene foi considerada muito interessante por 
parte dos estudantes que se demonstraram abertos a novas leituras, desafios e apresentação de novos métodos de ensino. 


\section{CONSIDERAÇÕES FINAIS}

Em 1973, Theodosius Dobzhansky publicou pela primeira vez em um artigo na revista American Zoologist, a afirmação "nada em biologia faz sentido senão à luz da evolução" (47). Hoje, 40 anos depois, podemos afirmar que nada faz sentido na área de ciências da vida se não à luz da Genética. E conceituar gene é absolutamente central, pois ainda é, e deverá continuar sendo, um conceito fundamental no melhor entendimento da ciência da hereditariedade. Dessa forma, o desenvolvimento de instrumental e metodologia que maximizem o melhor entendimento desse conceito é cada vez mais importante para os nossos estudantes e toda a sociedade.

A utilização de tirinhas no processo de ensino-aprendizagem se mostrou eficiente, como pode ser observado pelos dados, na melhoria do entendimento do conceito de gene. Ainda, aproximadamente 50\% dos estudantes avaliaram que a tirinha e a estratégia didática aqui adotadas foram muito interessantes e contribuíram para o melhor entendimento do conceito. Por outro lado, ao menos $1 / 4$ dos estudantes apontou que a metodologia é moderamente relevante, mesmo tendo contribuído para o melhor entendimento do conceito. Questiona-se se essa resposta não esteja atrelada a um certo preconceito no uso do material que foi classificado como "infantil” por alguns estudantes. A produção de tirinhas autorais foi também um sucesso nas turmas analisadas, como demonstrado pelo entusiasmo e qualidade da maior parte das tirinhas. Convém comentar que os resultados aqui apresentados deverão ser testados em novas turmas e outras Instituições de ensino visando aumentar a validade e fidedignidade interna dos dados e analises.

Dessa forma, concluímos que a estratégia didática utilizando tirinhas contribui com a desconstrução e reconstrução de conceitos e deve ser testada com outros conceitos na Genética. 


\section{REFERÊNCIAS}

1. Cabello KSA, La Rocque L, Sousa ICF. Uma história em quadrinhos para o ensino e divulgação da hanseníase. Revista Electrónica de Enseñanza de las Ciências. 2010:9(1):225-241.

2. Araújo-Jorge TC. Relações entre ciência, arte e educação: relevância e inovação. Revista E, São Paulo SESC. 2007;12.

3. Caruso $F$, Carvalho $M$, Silveira MCO. Ensino não formal no campo das Ciências por meio dos quadrinhos. Ciência e Cultura, Campinas. 2005;57(4):33-35.

4. Pizarro MV, Junior JL. A história em quadrinhos como recurso didático no ensino de indicadores da alfabetização científica nas séries iniciais. VII Encontro Nacional em Educação em Ciências. Florianópolis. 2009.

5. El-Hani CN. Between the cross and the sword: The crisis of the gene concept. Genetics and Molecular Biology. 2007;30:297-307.

6. Boujemaa A, Pierre C, Sabah S, Salaheddine K, Jamal C, Abdellatif C. University students' conceptions about the concept of gene: Interest of historical approach. US-China Education Review. 2010;7(2):9-15.

7. Joaquim LM, El-Hani CN. A genética em transformação: crise e revisão do conceito de gene. Scientla Studia. 2010;8(1): 93-128.

8. Nascimento LMM. Como ensinar a estudantes universitários de Ciências Biológicas e Ciências da saúde sobre a crise do conceito de gene? [Dissertação de Mestrado]. Universidade Federal da Bahia. 2010. 
9. Gericke NM, Hagberg EM. Definition of historical models of gene function and their relation to students" understanding of genetics. Science and Education. 2007; 16:849-881.

10. Goldbach T, El-Hani CN. Entre Receitas, Programas e Códigos: Metáforas e Ideias Sobre Genes na Divulgação Cientifica e no Contexto Escolar. Revista de Educação em Ciência e Tecnologia. 2008;1:153-189.

11. Banet E, Ayuso GE. Teaching of biological inheritance and evolution of living beings in secondary school. Int. J. Sci. Educ. 2003;25(3):373-407.

12. Santos S. Para geneticistas e educadores: o conhecimento cotidiano sobre herança biológica. Ed. Anablume, Fapesp e Sociedade Brasileira de Genética. 2005.

13. Richards M. Lay knowledge of inheritance and genetics risk: a review and a hypothesis. Health Care Analysis. 1996; 4:1861-1864.

14. Nelkin D, Lindee SM. The DNA mystique: The gene as a cultural icon. New York: Freeman. 1995.

15. Pitombo MA, Almeida AMR, El-Hani CN. Gene concepts in higher education cell \& molecular biology textbooks. In: Proceedings of the loste International Meeting on Critical Analysis of School Science Textbook. University of Tunis. 2007:855-864.

16. Oliveira TB, Schneider EM, Meglhioratti FA. Percepções de professores de biologia em relação aos desafios do ensino de interação e expressão gênica. In: V Encontro Regional Sul de Ensino de Biologia (EREBIO-SUL); IV Simpósio Latino Americano e Caribenho de Educação em Ciências do Internacional Council of Associativos for Science Education (ICASE). 2011.

17. Klautau-Guimarães MN, Paiva SG, Oliveira SF. Herança monogênica: além de Mendel, além de DNA. Revista Genética na Escola. 2014; 9(2). 
18. Andrade G, Pedreira MM, Oliveira SF, Klautau-Guimarães MN. Compreendendo o jogo do dominó: elaboração de um recurso visual. In: 58 Congresso Brasileiro de Genética. Foz do Iguaçu - Brasil. 2012.

19. Gericke N, Hagberg M. Definition of Historical Models of Gene Function and their Relation to Students' Understandings of Genetics. Science \& Education. 2007;16:849-881.

20. Falk R. The gene - A concept in tension. In: Beurton PJ, Falk R, Rheinberger $\mathrm{H}$ (eds.). The Concept of the Gene in Development and Evolution. Cambridge: Cambridge University Press. 2000;317-348.

21. Keller EF, Harel D. Beyond the gene. PLoS ONE. 2007; 2(11).

22. Joaquim LM, Santos VC, Almeida AMRA, Magalhães JC, El-Hani CN. Concepções de estudantes de graduação de biologia da UFPR e UFBA sobre genes e sua mudança pelo ensino de genética. Atas do VI ENPEC. 2007.

23. Griffiths PE, Neumann-Held E. The many faces of the gene. BioScience. 1999;49:656-662.

24. Moss L. Deconstructing the gene and reconstructing molecular developmental systems, In: Oyama S, Griffiths PE, Gray RD. Cycles of Contingency: Developmental Systems and Evolution. Cambridge-MA: MIT Press. 2001:85-98.

25. Moss L. What Genes Can't Do. Cambridge-MA: MIT Press. 2003.

26. International Human Genome Sequencing Consortium, 2004

27. Encode Project Consortium, 2012 
28. The 1000 Genomes Project Consortium, 2012

29. Santos VC, El-Hani CN. Ideias sobre genes em livros didáticos de biologia do ensino médio publicados no Brasil. Revista Brasileira de Pesquisa em Educação em Ciências, 2001;9(1).

30. Portin P. The concept of the gene: short history and present status. Quarterly Review of Biology. 1993;56:173-223.

31. Keller EF. The century of the gene. Cambridge-MA: Harvard University Press. 2000.

32. Fogle T. The dissolution of protein coding genes. In: P. Beurton, R. Falk, e $\mathrm{H}$ - J. Rheinberger (Eds.), The concept of the gene in development and evolution (p. 3-25). Cambridge-UK: Cambridge University Press. 2000.

33. Pardini MIMC, Guimarães RC. A systemic concept of the gene. Genetics and Molecular Biology. 1992;15:713-721.

34. Fogle T. Are genes units of inheritance? Biology and Philosophy. 1990;(5):349-371.

35. Gerstein MB, Bruce C, Rozowsky JS, Zheng D, Du J, Korbel JO, et al. What is a gene, post-ENCODE? History and updated definition. Genome Research. 2007;17:669-681.

36. Smith M, Adkison L. Updating the model definition of the gene in the modern genomic era with implications for instruction. Science \& Education. 2010;19:1-20.

37. El-Hani CN, Roque N, Rocha PLB. Livros didáticos de biologia do ensino médio: resultados do PNLEM/2007. 2011;27(1):211-240. 
38. Banti RS. A utilização das Histórias em Quadrinhos no Ensino de Ciências e Biologia. [Trabalho de Conclusão de Curso]. Universidade Presbiteriana Mackenzie. São Paulo. 2012.

39. Nicolau V. Tirinhas e mídias digitais. Marca de Fantasias. João Pessoa. 2013.

40. Silva RA, Guimarães MM. Arte Educação: Facilitando o Ensino de Morfologia. Educere Revista da Educação. 2004;4(1):55-63.

41. Testoni AT. Um corpo que cai: As Histórias em Quadrinhos no Ensino de Física [Dissertação de Mestrado]. Universidade de São Paulo. 2004.

42. Testoni LA, Abib MLVS. A Utilização de Histórias em Quadrinhos no Ensino de Física. Relatório de Qualificação apresentado à Comissão de PósGraduação da FEUSP. 2003.

43. Amabis, J.M. e Martho, G.R. Fundamentos da Biologia Moderna. São Paulo: Moderna. 2006.

44. Alcoforado LF. Notas de aula: Questionários e escalas. Departamento de Estatística/ UFF. 2011. Disponível em: < http://www.professores.uff.br/luciane/images/stories/Arquivos/doc_turismo/qu est_escalas_cap1.pdf>. Acesso em: 9 out 2014.

45. Falk R. What is a gene? Studies in the History and Philosophy of Science. 1986;17:133-173.

46. Joaquim, L. M. Genes: questões epistemológicas, conceitos relacionados e visões de estudantes de graduação [Dissertação de mestrado] Universidade Federal da Bahia. Bahia. 2009. 
47. Dobzhanski T. Nothing in biology makes sense except in the light of evolution. The American Biology Teacher. 1973;35(3):125-129. 
ANEXOS 


\section{Anexo 1 - Texto utilizado na sequência didática sobre os modelos históricos de gene (Nascimento, 2010).}

\section{Texto 1 - "Modelos Históricos do Conceito de Gene"}

Nós sempre temos dúvidas sobre o que é parte e o que não é parte de um gene. Os genes possuem, por exemplo, íntrons, que são regiões não codificadoras. Íntrons fazem ou não fazem parte dos genes? Existem sequências regulatórias que influenciam transcrição de um gene, mas estão muito distantes do gene, a até 1.000 pares de bases. Faz sentido incluir essas sequências no gene? Para responder essas perguntas, é importante entender como nossas ideias sobre genes evoluíram ao longo do século XX.

$O$ termo gene foi introduzido pelo geneticista dinamarquês Wilhelm Johanneson, em 1909. Antes dele, o austríaco Grego Mendel, no século XIX, chamou de "fatores" certas unidades que ele supôs que seriam passadas de uma geração para a próxima sem alterações, mas que não eram então conhecidas. (Smith e Adkison, 2008, p. 04). No final do século XIX, o zoólogo August Weismann propôs a existência de elementos particulados, auto reprodutores, que determinariam as propriedades de um organismo, que ele chamou de "determinantes". Essa suposição não era exclusiva de Weismann - o naturalista inglês Charles Darwin propusera anteriormente a existência de algum elemento desse tipo, que ele chamou de "gêmulas". E o botânico holandês Hugo De Vries, em 1889, também sugeriu a existência de unidades elementares de hereditariedade, que ele chamou de "pangenes", em um esforço para preservar o que havia de melhor tanto nas gêmulas de Darwin como nos determinantes de Weismann. (Keller, 2000, p. 13 e 29). Todas estas eram tentativas iniciais de compreender a herança, em bases fortemente especulativas. No começo do século $X X$, contudo, os avanços se tornaram mais rápidos, com o nascimento da genética. Isso não quer dizer, contudo, que os primeiros geneticistas não enfrentavam grandes dificuldades para compreender a herança e suas bases materiais. Um exemplo disso é o conceito de caráter unitário (unit-character), usado pelos geneticistas do início do século passado.

O termo gene foi cunhado por Johannsen como uma tentativa de simplificar as ideias envolvidas no termo anteriormente muito usado pelos geneticistas - caráter unitário. Por caráter unitário era entendido: (1) qualquer caráter visível de um organismo que se comporta como uma unidade indivisível de herança mendeliana e (2) por extensão, algo na célula germinativa que produz o caráter visível. Johannsen mostrou que essas duas coisas eram logicamente distintas; sugeriu o termo gene para o que determinava hipoteticamente na célula germinativa; e tornou claro que não é possível dizer quantos determinantes germinativos (genes) estavam envolvidos na produção de único caráter visível. (Falk, 1986, p. 141-142).

O termo gene foi construído por Johannsen no contexto de uma tentativa de diferenciar fenótipo de genótipo, ou seja, para explicar a diferença entre o potencial para um traço e o próprio traço. Ao fazer isso, ele abriu caminho para os futuros desenvolvimentos do conceito de gene. (Falk, 1986, p. 136).

Naquele momento, no começo da genética, predominava uma visão instrumental sobre a natureza do gene. Mas, o que é um conceito 
instrumental? Uma postura instrumentalista considera que os conceitos teóricos devem ser entendidos como ficções úteis, que facilitam nossos cálculos, ou seja, ferramentas que possibilitam controlar o mundo observável, não devendo ser julgadas em termos de verdade ou falsidade, mas em termos de sua utilidade como instrumentos. (Chalmers, 1993).

Assim como Mendel fez com seus famosos 'fatores', Johannsen também considerou inicialmente o gene simplesmente como uma unidade útil para interpretar experimentos nos quais indivíduos eram cruzados entre si. Estes dois cientistas não concebiam uma entidade material clara ao qual o gene corresponderia. O conceito de gene era abstrato, dissociado das coisas reais, deliberadamente criado para representar uma unidade capaz de orientar a interpretação de resultados experimentais, sem qualquer hipótese sobre sua composição ou estrutura. (El-Hani, 2007, p. 298). Esta era uma atitude instrumentalista que resultava do estado do conhecimento nos primeiros tempos da genética.

Bom, agora que conhecemos a origem do termo gene e a natureza instrumental atribuída a ele no momento em que o conceito foi cunhado, vamos conhecer o primeiro modelo de gene da história da genética, o Modelo Mendeliano.

No Modelo Mendeliano, o gene é visto da maneira instrumentalista mencionada acima e seu propósito principal é explicar a transmissão genética. O gene é uma ideia abstrata, não uma entidade física, uma unidade material - fisiológica ou química - direta. O gene é uma unidade de transmissão e função. O genótipo é visto como um fenótipo em miniatura, um mosaico de partículas hereditárias, cada uma responsável por uma característica fenotípica. Supõe-se uma relação de um para um entre os genes e as características. A função do gene é definida "de cima para baixo", ou seja, partindo de um traço ao nível do fenótipo, deduz-se um gene com certa função ao nível do genótipo (Gericke e Hagberg, 2007, p. 17). Notem que esta relação é o inverso do que estamos acostumados a pensar hoje. Hoje concluímos quais são as características a partir dos genes. Naquela época, concluía-se quais são os genes a partir das características, já que não havia técnicas que permitissem coletar dados diretamente sobre genes.

$\mathrm{Na}$ mesma época do modelo mendeliano, com sua postura instrumentalista, havia quem defendesse uma noção, ainda vaga, da materialidade do gene, ou seja, quem atribuísse realidade ao gene. Mas, o que significa um conceito ser realista? Neste caso, os conceitos são vistos como representações (em certo grau) de aspectos do mundo (Giere, 1988). Os objetos aos quais os conceitos se referem são entendidos como existindo de fato no mundo (Hacking, 1983). Eles são mais do que ficções para interpretar resultados experimentais: eles realmente existem, no caso de uma visão realista!

Um dos primeiros defensores da materialidade do gene foi Herman Muller. Para ele, os genes realmente existiam, ainda que, na época, a única forma de reconhecer a sua presença fosse pelos seus efeitos: "... estão presentes dentro da célula milhares de substâncias distintas - os 'genes'; esses genes existem como partículas ultramicroscópicas; sua influência, entretanto, permeia toda a célula... os genes estão no cromossomo... A composição química dos genes, e as fórmulas das suas reações permanecem ainda bem desconhecidas". "O que eu quero dizer... com o 
termo 'gene' material é qualquer substância que, em dados meios... é capaz de causar a reprodução de sua própria composição específica, mas que pode, no entanto, mudar repetidamente - 'mutar' - e ainda manter a propriedade de se reproduzir em suas várias novas formas". (Muller, 1922, citado por Falk, 1986, p. 149-150).

A partir dessa noção vaga sobre a natureza material do gene, foram desenvolvidos o segundo e o terceiro modelos de gene construídos pelos geneticistas - o Modelo Clássico e o Modelo Bioquímico.

O Modelo Clássico de gene foi desenvolvido por volta dos anos 1940, quando a genética combinava análise de cruzamentos com estudos de citologia, embriologia e reprodução. Nesse tempo, o gene era descrito como uma unidade material indivisível encontrada no cromossomo. O cromossomo era visto como sendo similar a um "colar de contas", cada conta sendo um gene. Benzer (1957) mostrou que os genes não eram, como se propunha antes, unidades de mutação, recombinação e função. Ele mostrou que várias mutações podem ser encontradas num gene; logo, a unidade de mutação devia ser menor do que um gene. A recombinação, por sua vez, envolvia muitos genes; logo, a unidade de recombinação deveria ser maior do que o gene. O gene passou a ser entendido, então, apenas como unidade de transmissão e de função (cistron). Esta unidade existia em diferentes variantes, chamadas de alelos. Existia então uma noção vaga de que o gene seria ou agiria como uma enzima, catalisando processos químicos no organismo, que resultariam nas características fenotípicas. As relações entre genótipo e fenótipo eram entendidas como relações causais simples: o gene simplesmente determinaria uma característica. (Gericke e Hagberg, 2007). A visão sobre o conceito de gene era, naquela época, ambígua, meio instrumentalista, meio realista.

A genética clássica das análises de reprodução e citologia de plantas e animais foi suplantada em meados do século por uma pesquisa genética baseada principalmente em experimentos microbiológicos com fungos, bactérias e vírus. Nesse contexto, foi desenvolvido o Modelo Bioquímico, no qual o gene continuava a ser descrito como uma unidade material indivisível encontrada no cromossomo e como uma unidade de função e transmissão, que existia em variantes chamadas de alelos, tal como no Modelo Clássico de gene. Entretanto, no modelo bioquímico, afirma-se de modo decisivo que - gene era responsável pela produção de uma enzima específica, que originava um traço. Não se aceitava mais, então, que o gene era, ele mesmo, uma enzima: parecia a idéia de que o gene produz enzimas. Esta foi a época em que Beadle e Tatum (1941) propuseram o célebre slogan: "um gene uma enzima" (Gericke e Hagberg, 2007). As relações abstratas do modelo clássico se tornam reações bioquímicas no modelo bioquímico. Entretanto, estas relações continuam sendo vistas como relações causais simples.

Com o crescimento do conhecimento da genética e através de uma série de desenvolvimentos que não discutiremos aqui, a visão instrumental foi substituída por uma compreensão material do gene (El-Hani, 2007, p. 298). Nas décadas de 1940 e 1950, uma compreensão das bases físico-química da herança era ativamente perseguida pelos pesquisadores. Mas, havia grandes dúvidas: no cromossomo, temos proteínas e ácidos nucléicos. Quais são as moléculas responsáveis pela herança? A aposta da maioria dos pesquisadores era de que proteínas seriam a base da herança. Afinal, são 
muitas as características de um organismo que são herdadas e as proteínas têm vinte blocos de construção (aminoácidos), contra quatro nucleotídeos dos ácidos nucléicos! Parecia mais correto pensar que proteínas poderiam ser responsáveis pela herança de tantas características diferentes.

No entanto, em 1944, Avery e seus colaboradores identificaram os ácidos nucléicos como a base material da hereditariedade. Para surpresa de muitos pesquisadores, eram os ácidos nucléicos a base da herança, não as proteínas que formavam com eles os cromossomos! Contudo, não havia ainda uma compreensão físico-química da organização desses ácidos nucléicos e de como eles poderiam mediar a herança (Keller, 2002). Foi então que, em 1953, Watson e Crick apresentaram o modelo da dupla hélice do DNA, o que fez com que esta molécula fosse reconhecida como a base material da herança (Keller 2002). Uma engenhosa hipótese encontrada neste modelo explicava como aquela molécula feita por quatro blocos de construção podia ser responsável pela herança de tantas características: a hipótese da sequência. De acordo com esta hipótese, apresentada por Crick (1958), a sequência de nucleotídeos correspondia à sequência de aminoácidos de uma proteína, e as proteínas constituem, por sua vez, o nível mais básico do fenótipo. Crick sintetizou isso no que chamou, de brincadeira, de dogma central da biologia molecular: o DNA faz RNA, o RNA faz proteínas, e as proteínas nos fazem. Isto é, o fluxo de informação é sempre do DNA para o RNA, e do RNA para a proteína, e nunca na direção oposta (Smith e Adkison,2008, p. 11). Isso depois mudaria, com a descoberta de um fluxo contrário do RNA para o DNA, mas jamais se descobriu um fluxo de informação de proteínas para RNA ou DNA.

O modo como Crick expressou o dogma da biologia molecular mostra como o reducionismo permanecia forte na genética! Mas esta foi, sem dúvida, uma hipótese poderosa: a partir dela Crick previu que existiria uma molécula que fazia com que nucleotídeos correspondessem a aminoácidos. Esta previsão foi cumprida quando foi descoberto o RNA transportador (tRNA). A partir desta previsão, elucidou-se o código genético, e assim por diante.

O modelo da dupla hélice explicava várias características necessárias ao material genético, como base da herança: auto-replicação, especificidade e conteúdo informacional (Gericke e Hagberg, 2007, p. 20). Com o modelo de Watson e Crick, a longa busca pela base material da herança havia terminado (Gericke e Hagberg, 2007, p. 20). O modelo da dupla hélice do DNA foi responsável pela aceitação ampla de uma visão realista sobre o conceito de gene, que passou a ser entendido como uma sequência específica e discreta de nucleotídeos de DNA, envolvido em uma função específica (Falk, 1986, p. 158; Keller, 2000, p. 15, 35-36). Este modelo foi a base para o Modelo Molecular Clássico de gene, de acordo com o qual um gene é um segmento de DNA que codifica um produto funcional, que pode ser uma cadeia polipeptídica ou uma molécula de RNA. Nesse conceito, o gene tem uma localização fixa no cromossomo e é tratado como uma unidade no genoma que não tem interrupções, com um começo e um fim claro, que desempenha uma única função. O gene permanece como unidade de função (cistron) e de herança, e passa a ser também uma unidade estrutura no genoma (El-Hani, 2007, p. 298; Gericke e Hagberg, 2007, p. 20). Nesse sentido, o modelo molecular clássico atualizou, em bases moleculares, 
a idéia mendeliana de unidade de herança, anterior ao nascimento da própria genética. Mas, mais do que isso a combinação de uma visão estrutural e funcional num modelo simples de gene molecular, com estrutura bem definida, limites facilmente determináveis e função única, levou a grandes avanços da pesquisa no campo então nascente da biologia molecular (ElHani,2007, p. 298).

Notem que, no modelo molecular clássico, o procedimento não é mais aquele da genética clássica: não se conclui o que é um gene a partir do fenótipo. Ao contrário, as explicações se concentram sobre a estrutura e função do gene no nível molecular, e o fenótipo é visto como consequência de relações moleculares. Estas relações causais já não são tão simples: elas são reações bioquímicas explicadas de modo detalhado. Vocês já devem ter notado que esse modelo é um dos mais frequentes nas salas de aula e nos livros didáticos, tanto no ensino médio como no ensino superior.

Outra novidade importante da década de 1950 foi que a genética e a biologia molecular começaram a usar cada vez mais termos que se referiam a 'informação', como, por exemplo: "informação genética"; "código genético", "programa". Isso tem sido chamado de "discurso da informação" (Kay, 2000). Daí surgiu uma outra noção muito popular em livros didáticos, na mídia e na opinião pública, a concepção informacional do gene. A concepção informacional pode ser vista como consequência do Modelo Molecular Clássico: os genes passaram a ser vistos, então, não apenas como unidades funcionais e estruturais, mas também como unidades informacionais. Essa visão informacional é uma nova encarnação, ou ao menos, uma extensão da visão funcional dos genes. (El-Hani, 2007, p. 298-299). Esse "discurso da informação" na biologia tem sido considerado problemático, no entanto, porque não se fornece definições claras e precisas do que se chama de 'informação' nesta ciência. Este termo mais parece uma metáfora do que um conceito, e não há ainda uma teoria da informação biológica consistente, que possa Ihe dar sentido claro e preciso (Griffiths, 2001). Mas esta já é uma outra história, que nos leva de um período em que a ciência veio produzindo uma compreensão cada vez mais clara dos genes e de seu papel para os seres vivos, para um novo tempo, a partir da década de 1970, no qual mais e mais dúvidas sobre o que são os genes e qual o seu papel foram se acumulando. Isso é, contudo, assunto para outra aula.

\section{Questões propostas:}

1) Os diagramas abaixo representam os modelos históricos do conceito de gene. Cada estudante deverá escolher um dos modelos e explicá-lo para os seus colegas de equipe. Com base no texto e na explicação do colega, a equipe deverá descobrir qual o modelo histórico representado em cada diagrama. 
a)



Codifica a produção de



b)

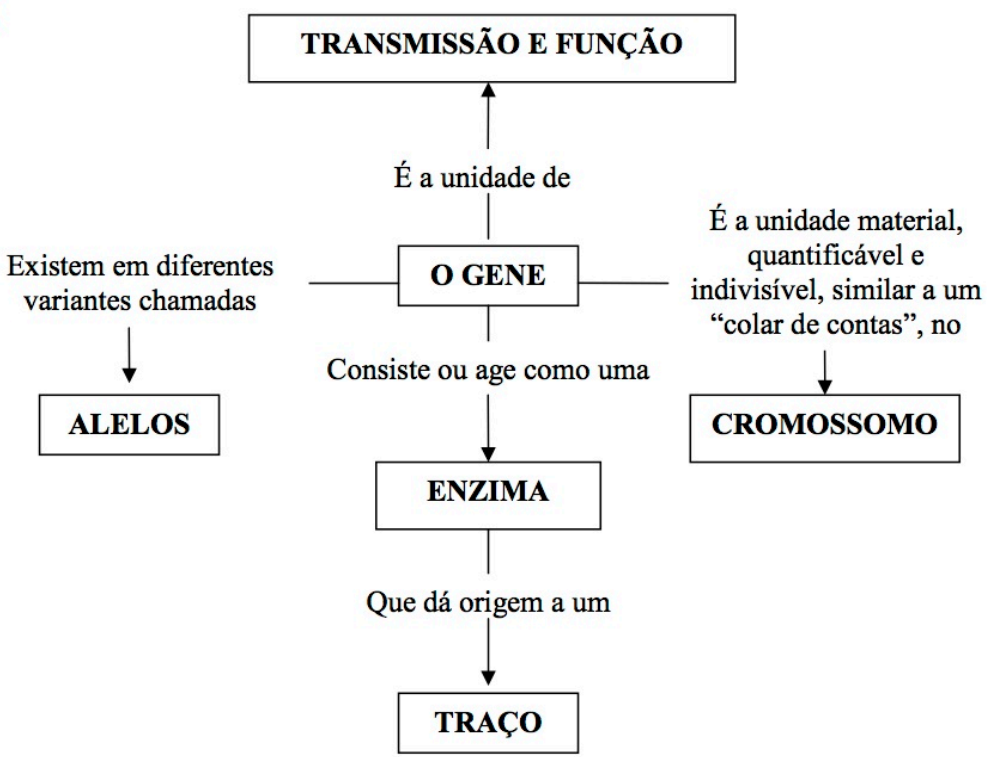

c)

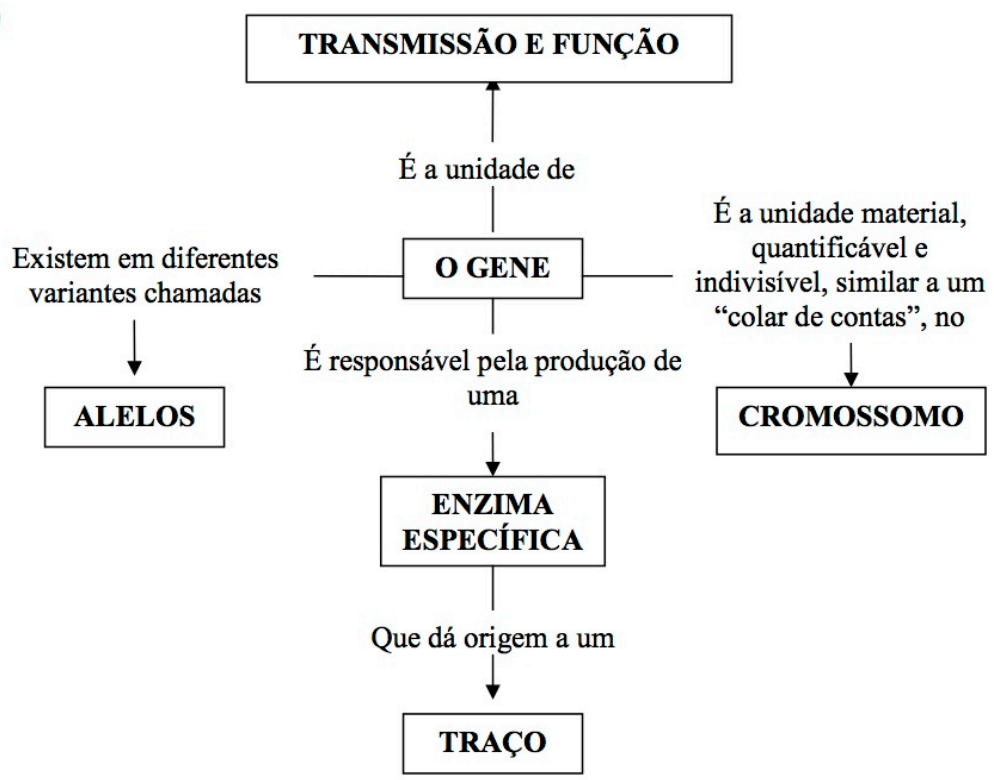


d)

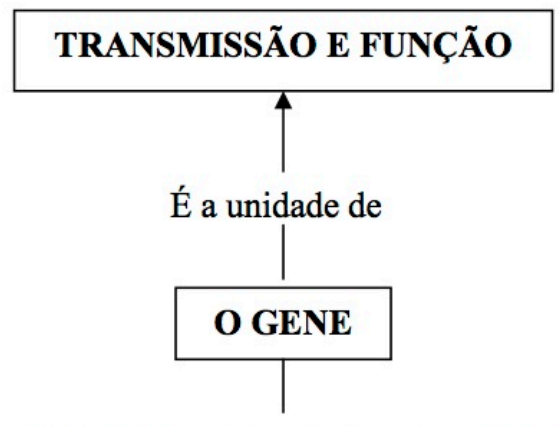

É visto como um fenótipo em miniatura, uma entidade abstrata sem conexão fisiológica ou química que é responsável por um

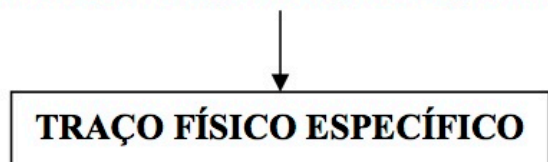

2) O que você entende por visão instrumentalista e visão realista?

3) Como você classifica cada um dos quatro modelos representados nos diagramas quanto a natureza do gene - instrumental ou real? Justifique a sua resposta.

\section{Referência do texto:}

Como ensinar a estudantes universitários de Ciências biológicas e ciências da saúde sobre a crise do conceito de gene? Lia Midori Meyer Nascimento (2010). Dissertação apresentada ao Programa de Pós-Graduação em Ensino, Filosofia e História das Ciências, da Universidade Federal da Bahia, como requisito parcial para a obtenção do titulo de Mestre. 


\title{
Anexo 2 - Texto utilizado na sequência didática sobre as novas propostas para o conceito de gene (Nascimento, 2010).
}

Texto 2 - Propostas para o conceito de gene

\begin{abstract}
Abandono do conceito de gene. Alguns autores, como Keller (2000), Gelbart (1998) e Portin (1993) propuseram o abandono do conceito de gene. Keller, por exemplo, escreve que o gene é um conceito problemático e sugere que chegou o tempo de forjar novas palavras e deixar este conceito de lado. Portin afirma que nosso conhecimento da estrutura e função do material genético ultrapassou a terminologia usada para descrevê-lo e que pode ser o caso de que o termo 'gene' não seja mais útil.
\end{abstract}

Genes como processos. Posteriormente, Keller (2005) mudou sua posição, afirmando que o conceito de gene poderia ser mantido, mas apenas no contexto de uma compreensão das complexas redes informacionais que constituem a célula e, além disso, de uma maneira mais dinâmica. Para ela, o século XXI será o século dos sistemas genéticos, não do gene. Para que este conceito não seja abandonado, então, será preciso enfrentar os desafios colocados pela complexidade biológica e construir novas maneiras de falar. Para compreender os sistemas de interação entre os componentes dos sistemas vivos, será preciso superar hábitos arraigados de pensamento e linguagem que dão prioridade às partes do sistema, em vez do sistema vivo como um todo. Estes hábitos são muito problemáticos quando genes são tomados como estas partes, porque genes não têm qualquer significado quando isolados. Keller trata a célula como um sistema de produção de significados que transforma sequências de nucleotídeos em genes. Neste contexto, o conceito de gene pode sobreviver no século XXI, mas apenas se genes passarem a ser entendidos como verbos, e não mais substantivos. Num tom similar, El-Hani, Queiroz e Emmeche (2009) argumentam que o significado de um gene não está contido na sequência de nucleotídeos do DNA, mas emerge como um processo que envolve o sistema pelo qual os genes são interpretados, que inclui a célula e, em alguns casos, até mesmo o ambiente supracelular. Genes não estão dados no DNA, portanto, mas são construídos pela célula. Esta visão é, na visão destes cientistas, fundamental para entendermos que não é o DNA que controla a célula, não é o DNA que faz coisas com a célula, como se costuma ensinar, mas a célula é que faz coisas com o DNA. O DNA é um repositório de informação biológica útil, e não um catalisador de processos, ou um programa de desenvolvimento, ou um controlador da célula.

Conceito sistêmico de gene (Pardini e Guimarães, 1992) - De acordo com o conceito sistêmico, "o gene é uma combinação de (uma ou mais) sequências de ácidos nucléicos (DNA ou RNA), definido pelo sistema (a célula inteira, interagindo com o ambiente) que corresponde a um produto (RNA ou polipeptídio)" (Pardini e Guimarães, 1992, p. 713 e 717). Essa definição trata o genoma como parte do sistema celular, que "constrói, define e usa o genoma como parte do seu mecanismo de memória, como um banco de dados interativo" (Guimarães e Moreira, 2000, p. 249, citado em El-Hani, 
2007, p. 305). Os autores ressaltam a dinâmica da relação entre a informação codificada e o produto da sua codificação, que é muito complexa e varia com as condições espaciais e temporais em que ocorre. Eles argumentam que o significado de um segmento de DNA é relativo, dependendo do sistema de expressão gênica no qual ele está inserido. Assim, seu significado pode ser plural: a natureza plural dos genes, particularmente em eucariotos, se origina da dependência da expressão gênica em relação ao contexto celular e supracelular (Pardini e Guimarães, 1992, p. 716; El-Hani, 2007, p. 305).

Conjunto de Domínios para Transcrição Ativa - DSATs (Fogle, 1990; 2000) - Em sua proposta, Fogle reconhece que o gene é construído pela reunião de domínios encontrados no DNA. Os 'domínios' são sequências de nucleotídeos que podem ser distinguidas umas das outras com base nas suas propriedades estruturais e/ou atividadesfunções: éxons, íntrons, promotores, intensificadores (enhancers), operadores etc. (Fogle, 1990, p. 367; El-Hani, 2007, p. 304). Essas sequências se combinam para formar genes e são necessárias para influenciar o fenótipo. Domínios podem ser combinados de variadas formas para formar conjuntos, ou como Fogle chamou, "conjunto de domínios para a transcrição ativa" (DSAT, do inglês) (El-Hani, 2007, p. 304). Essa estrutura de conjuntos elimina a necessidade de encontrar uma única unidade genética que corresponderia a um gene. Um domínio pode fazer parte de mais de um gene e os genes não se encontram no DNA, sendo construídos pela célula. São os domínios que se encontram no DNA. Assim, torna-se mais fácil acomodar fenômenos como genes encontrados dentro de outros genes e genes sobrepostos (Fogle, 1990, p. 367).

Conceito Molecular Processual de Gene (Griffiths e Neumann-Held, 1999) - O conceito de gene molecular processual propõe tratar os genes não como meras sequências no DNA, mas como todo o processo molecular subjacente à expressão de um produto particular (um polipeptídio ou um RNA) (Griffiths e Neumann-Held, 1999, p.661). Desta perspectiva, o 'gene' é um processo que ocorre repetidas vezes e conduz à expressão regulada de um produto polipeptídico particular (Griffiths e Neumann-Held, 1999, p.659). A proposta de Griffiths e Neumann-Held trata os genes, portanto, como processos, e não entidades físicas no DNA. A natureza processual desse conceito torna possível acomodar anomalias que o modelo molecular clássico tem dificuldade de enfrentar, tal como splicing alternativo e edição de mRNA. A chave para se lidar com essas anomalias está no fato de o conceito de gene molecular processual incluir no gene os próprios processos de splicing alternativo e edição de mRNA (El-Hani, 2007, p. 303; Griffiths e NeumannHeld, 1999, p. 659). Se, a partir da mesma sequência de DNA, dois produtos proteicos são originados a partir de padrões diferentes de splicing, temos aí dois genes moleculares processuais, porque temos dois processos distintos de splicing.

Gene-P e Gene-D (Moss, 2001; 2003) - A proposta de Moss, diferentemente das demais apresentadas aqui, não oferece uma nova definição para gene. $O$ que ele propõe é uma distinção de dois significados atribuídos ao conceito, 
gene- $P$ e gene- $D$, os quais são frequentemente misturados na referência de um único termo "gene", tanto por cientistas, professores, estudantes, opinião pública etc. Esta é uma confusão com importantes consequências sociais, porque dá força ao determinismo genético, a idéia de que temos uma série de características, mesmo bastante complexas (comportamentos, inteligência etc.), que seriam determinadas apenas por genes. De um lado, temos o gene-P: o gene como determinante de fenótipos ou diferenças fenotípicas. De outro, o gene-D: o gene como recurso para o desenvolvimento. O Gene-P é um instrumento para a realização de algumas tarefas relevantes na genética, como a análise de genealogias ou heredogramas. Quando se fala de um gene no sentido do Gene-P, fala-se simplesmente como se ele causasse o fenótipo. Por exemplo, quando falamos em gene para olhos azuis, falamos como se houvesse um gene que determina essa cor de olhos: este é um Gene-P. Contudo, não existe um gene para olhos azuis. Olhos podem ficar menos pigmentados por uma diversidade de problemas na via de síntese de pigmentos na íris, que têm origem em mutações numa diversidade de genes. Contudo, para entender o resultado de um cruzamento entre um pai de olhos castanhos e uma mãe de olhos azuis, podemos simplificar a situação e falar como se houvesse um gene que determina olhos azuis. Este gene-P é uma ficção útil para realizar essa tarefa da genética, a análise de heredogramas, a previsão de resultados de cruzamentos. Por sua vez, o gene-D é considerado uma entidade real, definido por alguma sequência molecular no DNA. Ele não determina, contudo, características fenotípicas. Ele é um recurso, entre vários recursos igualmente importantes (genéticos, epigenéticos, ambientais), para que ocorra o desenvolvimento de características. O gene-D cumpre papéis distintos do gene- $P$, em outras tarefas importantes desempenhadas por geneticistas e biólogos moleculares. Gene-P e Gene-D são conceitos distintos, que apresentam ideias diferentes sobre o que é um gene. Não existe qualquer pedaço de DNA, ou qualquer outra coisa que seja simultaneamente Gene-P e Gene-D (Moss, 2001, p. 4; El-Hani, 2007, p. 304). Temos aqui um exemplo de como a hibridização de conceitos e modelos pode ser perigosa: se confundimos o gene-P, que não existe e é pensado como se determinasse características, com o gene-D, que existe, mas não determina características, concluiremos que, apesar de toda a complexidade do desenvolvimento, há características determinadas apenas por genes. Nós nos tornaremos convencidos de que o determinismo genético é correto. Isso ocorre o tempo todo, porque as pessoas hibridizam essas duas ideias. Se não as confundimos, saberemos que gene-P são importantes para fazer tarefas como analisar genealogias, mas não existem. São ficções úteis. Falamos como se determinassem características, mas apenas para facilitar a análise das genealogias. E saberemos também que genes- $D$, aqueles que estão lá nas células, não determinam características. Teremos consciência de que a construção das características fenotípicas é um processo complexo, raramente redutível à expressão de um único gene.

Conceito de gene do Projeto Genoma Humano - PGH (Venter et al. 2001; Smith e Adikson, 2008) - O PGH teve como objetivo principal determinar a sequência do DNA humano e identificar os genes codificados nele. Na "Era Genômica Moderna", quando o genoma humano foi sequenciado, genes são identificados de fato pelos chamados quadros de leitura aberta (ORFs). ORFs 
são sequências de nucleotídeos em uma molécula de DNA que tem potencial para codificar um polipeptídeo ou uma proteína e que contem também as sequências correspondentes aos códons de iniciação (AUG) e de terminação (UAA, UAG, UGA) da transcrição. Desta forma, houve uma mudança sucessiva no foco da genética: a função através das gerações (herancatransmissão) foi substituída, primeiro, pela função no indivíduo, depois, pelas sequências funcionais, e então, pela pesquisa atual das funções das sequências determinadas pelo PGH (Smith e Adkison, 2008, p. 8, 9 e 12). Num glossário associado ao $\mathrm{PGH}$, o gene é definido como "a unidade física e funcional fundamental da hereditariedade. Um gene é uma sequência ordenada de nucleotídeos localizada em uma posição particular em um cromossomo particular que codifica um produto funcional específico (i.e., uma proteína ou molécula de RNA)" (http://www.ornl.gov/sci/techresources/Human_Genome/glossary/glossary_g. shtml). Esta é uma definição que pode ser considerada conservadora nos dias de hoje, correspondendo ao modelo molecular clássico. Contudo, num dos artigos que apresentaram o esboço da sequência do genoma humano, em 2001, encontramos outra compreensão do gene, distinta do modelo molecular clássico. Venter et al. (2001, p. 1317) afirmam que um gene é um lócus de éxons co-transcritos, a partir da consideração de que um único gene pode originar múltiplos transcritos e, portanto, múltiplas proteínas distintas com múltiplas funções, por meio do splicing alternativo e de sítios alternativos de iniciação e terminação da transcrição.

Genon e Transgenon (Scherrer e Jost, 2007a, b) - Nessa proposta, os autores localizam o gene na sequência ininterrupta de ácidos nucléicos que emerge apenas no nível do mRNA, antes da tradução. Eles explicam que a sequência ininterrupta de mRNA é a unidade de função e análise genética, uma vez que, ao ser traduzida fielmente, constitui o equivalente da cadeia de polipeptídios produzida. Na sua definição, os autores também adicionam à sequência do mRNA as sequências regulatórias no transcrito e os produtos que atuam sobre a regulação gênica. Para dar conta desses fatores adicionados à sequência codificante, os autores cunharam os termos Genon e Transgenon. O Genon (contração das palavras 'gene' e 'operon') se refere ao programa associado à sequência codificadora no mesmo cromossomo do qual foi transcrito o mRNA, que regula a transcrição de um gene. O conjunto dos fatores regulatórios codificados por outros cromossomos relacionados a um dado genon é chamado por eles de Transgenon. Uma consequência dessa definição é que, em muitos casos nos eucariotos, o gene não pode ser diretamente identificado no nível do DNA, uma vez que no DNA a sequência é interrompida por íntrons. Ao invés disso, o gene é construído no processamento do RNA, incluindo, por exemplo, o splicing alternativo de vários éxons dirigida pelo Genon e a edição do mRNA dirigida pelo Transgenon. $O$ gene finalmente emerge como uma sequência ininterrupta de ácidos nucléicos no nível do mRNA, antes da tradução, com uma correspondência fiel com a sequência de aminoácidos produzida na síntese de um polipeptídio. Depois da tradução, o genon termina seu papel e desaparece (Scherrer e Jost, 2007b, p. 65-70; 2007a, p. 3-6). 
ENCODE (Gerstein et al. 2007; Smith e Adkison, 2008) - A mais recente pesquisa a ter um impacto importante em nosso entendimento sobre os genes e o genoma é o projeto ENCODE (Enciclopédia de Elementos do DNA). O ENCODE é um consórcio internacional de cientistas que busca identificar as funções de vários tipos de elementos conhecidos no DNA, como éxons, íntrons, promotores, terminadores etc. Baseados nos seus achados, cientistas do ENCODE argumentam que uma sequência, para ser um gene, deve satisfazer às seguintes condições: 1 . O gene é uma sequência genômica (de DNA ou RNA) que codifica diretamente produtos moleculares funcionais, seja RNA ou proteína; 2 . No caso em que há muitos produtos funcionais compartilhando regiões sobrepostas, entende-se como gene a união de todas as sequências genômicas sobrepostas que os codificam; 3 . Essa união deve ser coerente, mas não requer que todos os produtos necessariamente compartilhem uma subsequência comum. A partir dessas condições, os cientistas do ENCODE definiram gene como a união de sequências genômicas que codificam um conjunto de produtos funcionais potencialmente sobrepostos. (Gerstein et al. 2007, p. 676 e 677; Smith e Adkison, 2008, p. 13 e 15). O foco dessa definição está nos produtos, e como consequência disso, não existe uma relação de um-para-um entre uma sequência codificadora no nível do DNA e um produto funcional (Scherrer e Jost, 2007b). Por exemplo, os produtos do splicing alternativo, como compartilham sequências em comum, são considerados produtos de um único gene. Entretanto, diferentes produtos proteicos que se originam de um único e grande transcrito de mRNA policistrônico não são considerados como derivados de um único gene se os produtos finais não compartilham qualquer bloco de sequência. (Smith e Adkison, 2008, p. 15).

\section{Questões propostas:}

1. Vocês identificam semelhanças entre algumas das propostas acima? Quais semelhanças percebem?

2. Qual a proposta de conceito de gene que mais lhe pareceu interessante frente à crise do modelo molecular clássico de gene. Justifique o porquê e discuta com os seus colegas de equipe a sua opinião. Ao final da discussão, verifiquem qual a opinião que prevaleceu na equipe.

\section{Referência do texto:}

Como ensinar a estudantes universitários de Ciências biológicas e ciências da saúde sobre a crise do conceito de gene? Lia Midori Meyer Nascimento (2010). Dissertação apresentada ao Programa de Pós-Graduação em Ensino, Filosofia e História das Ciências, da Universidade Federal da Bahia, como requisito parcial para a obtenção do titulo de Mestre. 


\section{Anexo 3 - Artigo publicado na Revista Brasileira de Genética na Escola, Vol. 9, N², P. 118, 2014.}

\section{Tirinhas no ensino da estrutura, função e conceito de gene}

Maria de Nazaré Klautau-Guimarães ${ }^{1}$, Mariana Marzullo Pedreira ${ }^{2}$, Silviene Fabiana de Oliveira ${ }^{1}$

${ }^{1}$ Departamento de Genética e Morfologia, Instituto de Ciências Biológicas, campus Darcy Ribeiro, Universidade de Brasília.

${ }^{2}$ Mestranda no PPG Ciências da Saúde, Departamento de Genética e Morfologia, Instituto de Ciências Biológicas, campus Darcy Ribeiro, Universidade de Brasília.

Autor para correspondência: nklautau@unb.br ou nazaklautau@gmail.com

\section{Resumo}

Essa proposta didática apresenta a interação entre a arte e a ciência na construção do conhecimento científico. Como arte, explora o potencial pedagógico das tirinhas que permite uma leitura rápida, dinâmica, crítica e reflexiva. Na ciência, aborda a crise do conceito molecular clássico do gene. Assim, espera-se que os estudantes sejam estimulados a organizar e comunicar as novidades sobre a estrutura e função do gene, de maneira criativa e para além do livro didático.

\section{Conceito de gene}

A introdução do conceito de gene, termo empregado pela primeira vez por Wilhelm L. Johannsen em 1909, foi um dos marcos da história da ciência no século $X X$. O conceito original de gene como unidade indivisível da herança mendeliana foi sendo modificado com os avanços do conhecimento do material genético, sendo que hoje o mais abordado no ensino é o conceito molecular: uma sequência de DNA responsável pela produção de uma molécula de RNA ou de um polipeptídio que desempenha uma função específica. Observa-se uma relação de 1:1:1 entre genes, produtos gênicos e função gênica, que perpassa uma noção de unidade. Este conceito está amplamente difundido tanto no nível escolar médio quanto no superior (ELHANI, 2007).

Com o aprofundamento nos conhecimentos sobre estrutura e funcionamento dos genomas, o conceito de gene passou a ser contestado, instalando-se assim uma crise que sugere que o mesmo passe por uma revisão. Determinados autores afirmam que o que está por trás da crise do modelo é justamente o tratamento dos genes como unidades (EL-HANI, 2007; MEYER, 2010; MEYER et al., 2013).

Apesar da discussão na área da Filosofia e História da Ciência, observa-se dificuldade na compreensão deste conceito por parte de todos os atores no processo de ensino-aprendizagem da genética. Nos livros didáticos do ensino médio e superior detecta-se uma proliferação de significados para o termo gene, o que pode levar à compreensão equivocada por parte dos estudantes (SANTOS; EL-HANI, 2009; PITOMBO et al. 2008). O conceito 
predominante para estudantes de graduação das áreas biológicas é o molecular clássico, com grande heterogeneidade dos conhecimentos prévios e dificuldades de organização dos conhecimentos adquiridos (MEYER, 2010; PEDREIRA et al., 2013). Nas principais revistas de divulgação científica observa-se a utilização de metáforas intimamente relacionadas ao determinismo genético (GOLDBACH; EL-HANI, 2008).

\section{Proposta pedagógica}

O ensino atual apresenta estratégias teóricas tradicionais que se apresentam inadequadas na construção dos conhecimentos científicos e como consequência, há grande perda de interesse por parte dos estudantes. Diante do quadro atual, faz-se necessário que os estudantes sejam estimulados a desenvolver sua curiosidade natural e o seu potencial criativo para muito além do livro didático. Nesse contexto, Araújo-Jorge (2007) apresenta relações entre ciência, arte e educação, onde lembra que "Grandes cientistas, como Galileu Galilei e Leonardo da Vinci, transitaram pelas vias de conexão entre a ciência e a arte, ao desenvolver o conhecimento e o comunicar das mais diferentes formas".

Caruso e Silveira (2009) argumentam que através da produção artística apresenta-se uma pedagogia que contempla articulações entre ensinoaprendizagem e conhecimento-sociedade integrando os conteúdos disciplinares. Estes autores apresentam novos horizontes das potencialidades das histórias em quadrinhos (HQs) de contribuir de forma diferenciada para a construção da cidadania, popularização da ciência e no ensino de ciência em todos os níveis. As tirinhas permitem fazer uma contextualização da aprendizagem do conceito que se pretende transmitir, como também, permitem uma leitura muito rápida e dinâmica o que estimula os estudantes a reler os conceitos de forma crítica e reflexiva.

Os estudos acadêmicos na área de Ensino de Ciências, a nível nacional e internacional, apresentam a utilização das HQs como recurso relevante para os diversos níveis de ensino. $E$ todos apontam a importância do professor na compreensão crítica do enredo das histórias, na seleção do material e no planejamento das atividades (Pizarro, 2009).

\section{Objetivos da atividade}

O objetivo deste material é introduzir tirinhas como recurso didático no ensino de genética, buscando enquadrar os desafios, estimular a discussão e o pensamento crítico relacionado ao conceito, estrutura e função do gene. Pretende-se contribuir para desmistificação de conceitos errôneos e de senso comum entre os estudantes a respeito do conceito molecular clássico do gene, através da linguagem e imagem dos quadrinhos.

Este material tem o seu foco voltado para o aprimoramento do conceito de gene para o ensino superior e formação de professores, preparando-os para estar sempre abertos aos conhecimentos novos e suas aplicações na sociedade. Os estudantes e professores terão a oportunidade de construir o seu próprio conhecimento diante de um desafio, as tirinhas, que requer pesquisa e elaboração de pequenos textos.

\section{Características específicas do material}


Com o intuito de conectar os estudantes ao novo material foi desenvolvido um personagem principal, que representa um estudante de graduação cursando a disciplina de Genética na universidade. O personagem foi inserido em três contextos comuns aos estudantes: 1 - estudar para uma prova, 2 - participar de palestras e 3 - bater papo em horas de diversão. A ideia central é que os estudantes, ao serem apresentados às tirinhas, identifiquem-se com o personagem, ficando confortáveis e estimulados a terem questionamentos ao longo da disciplina.

A tirinha Estudando para a prova (Fig. 1) busca dinamizar o questionamento do conceito de gene. Nesse contexto, o estudante é apresentado estudando em diferentes fontes e pensando em vários conceitos de genética. $O$ grande desafio seria em como fazer a relação completa entre o conhecimento atual na área de Biologia Molecular, buscando uma definição atual de gene que leve em consideração as recentes descobertas sobre a estrutura, a organização e a regulação do gene. A tirinha Genética no bar (Fig. 2) foi desenvolvida para priorizar o caráter argumentativo dos estudantes, enquanto questiona a relação "um gene: uma proteína" após os resultados do Projeto Genoma Humano. Essa atividade proporciona ao estudante a organização dos seus conhecimentos para depois explicá-los e justificá-los, mesmo que para uma plateia fora do meio acadêmico. A tirinha Palestra (Fig. 3) retrata a participação de estudantes em eventos como seminários, palestras ou congressos e objetiva abordar a relação entre a estrutura física do gene e a sequência de aminoácidos de uma proteína, de uma maneira inversa ao que é tradicionalmente ensinado no Dogma Central da Biologia Molecular.

\section{Procedimento de aplicação do material}

Aqui são apresentadas três propostas de aplicação do material didático de acordo com os objetivos almejados. Isso não impede que outras formas de aplicação sejam sugeridas. Como o objetivo é de construção do conhecimento, o estudante não recebe um material pronto. Dessa forma, não se espera que existam respostas exatas e sim, que as mesmas sejam elaboradas de forma dinâmica com consultas, discussões, trocas de ideias entre os estudantes e a orientação do docente responsável.

(Proposta A) Avaliação dos conhecimentos prévios. Nessa proposta as tirinhas são apresentadas individualmente aos estudantes no início da disciplina e é solicitado que apresentem respostas sem consulta, utilizando apenas o conhecimento prévio ao início da disciplina. Com esta avaliação, o docente poderá estruturar melhor as abordagens desse tema em sua disciplina. Após uma apresentação teórica do conteúdo, os estudantes podem receber suas respostas e rever criticamente as mesmas.

(Proposta B) Construção do conhecimento sobre a estrutura, função e conceito do gene, coerente com os conhecimentos científicos atuais. Para esta proposta é sugerido que as tirinhas sejam aplicadas aos estudantes, em duplas, promovendo a busca de informações em fontes adequadas. Para este objetivo sugerimos a utilização do texto elaborado por Meyer (2010), ou que seja estimulada a busca em outras fontes ou que se utilizem os textos de revisão citados.

(Proposta C) Estimular o estudante para a leitura, o estudo e a contextualização do conceito. Nesta proposta os estudantes são incentivados 
a construir tirinhas autorais a partir de suas indagações, pesquisas na mídia e discussão de artigos de revisão em sala de aula. Após a elaboração das tirinhas em duplas ou grupos, sugere-se a apresentação à turma, com enfoque no contexto e nas possíveis leituras que a tirinha permita.

\section{Referências}

ARAUJO-JORGE, T. C. Relações entre ciência, arte e educação: relevância e inovação. Revista E, São Paulo Sesc, p. 12, 2007.

CARUSO, F. e SILVEIRA, C. Quadrinhos para a cidadania. História, Ciência e Saúde - Manguinhos, Rio de Janeiro, v.16, n.1, p.217-236, 2009

EL-HANI, C. N. Between the Cross and the Sword: The Crisis of the Gene Concept. Genetics and Molecular Biology (Impresso). v. 30, p. 297-307, 2007.

GOLDBACH, T.; EL-HANI, C.N. Entre Receitas, Programas e Códigos: Metáforas e Ideias Sobre Genes na Divulgação Científica e no Contexto Escolar. Revista de Educação em Ciência e Tecnologia. Vol 1, p. 153-189, 2008.

MEYER, L. M. N.; BOMFIM, G. C.; EL-HANI, C. N. How to Understand the Gene in the Twenty-First Century? Science \& Education (Dordrecht). Vol 22, p. 345-374, 2013.

MEYER, L. M. N. Como ensinar a estudantes universitários de Ciências Biológicas e Ciências da saúde sobre a crise do conceito de gene? Universidade Federal da Bahia. Dissertação de Mestrado. 2010. Disponível em:

http://twiki.ufba.br/twiki/pub/PPGEFHC/DissertacoesPpgefhc/Lia_Midori_Mey er_Nascimento_2010.pdf >. Disponível em: 17/02/2014.

PEDREIRA, M. M.; RESENDE, T. A.; OLIVEIRA, S. F.; KLAUTAUGUIMARÃES, M. N. Tirinhas no ensino de genética: potencial para avaliação dos conhecimentos prévios sobre os genes. Enseñanza de las Ciências. Vol extra, p. 2695-2700, 2013.

PITOMBO, M. A.; ALMEIDA, A. M. R.; EL-HANI, C. N. Conceitos de gene e ideias sobre função gênica em livros didáticos de biologia celular e molecular do ensino superior. Contexto \& Educação. Vol. 77, p. 81-110, 2008.

PIZARRO, M. V. As histórias em quadrinhos como linguagem e recurso didático no ensino de ciências. VII Enpec. Florianópolis. 2009.

SANTOS, V.C.; EL-HANI, C. N. Ideias sobre genes em livros didáticos de biologia do ensino médio publicados no Brasil. Revista Brasileira de Pesquisa em Educação em Ciências. Vol. 9, n.1, 2009. 


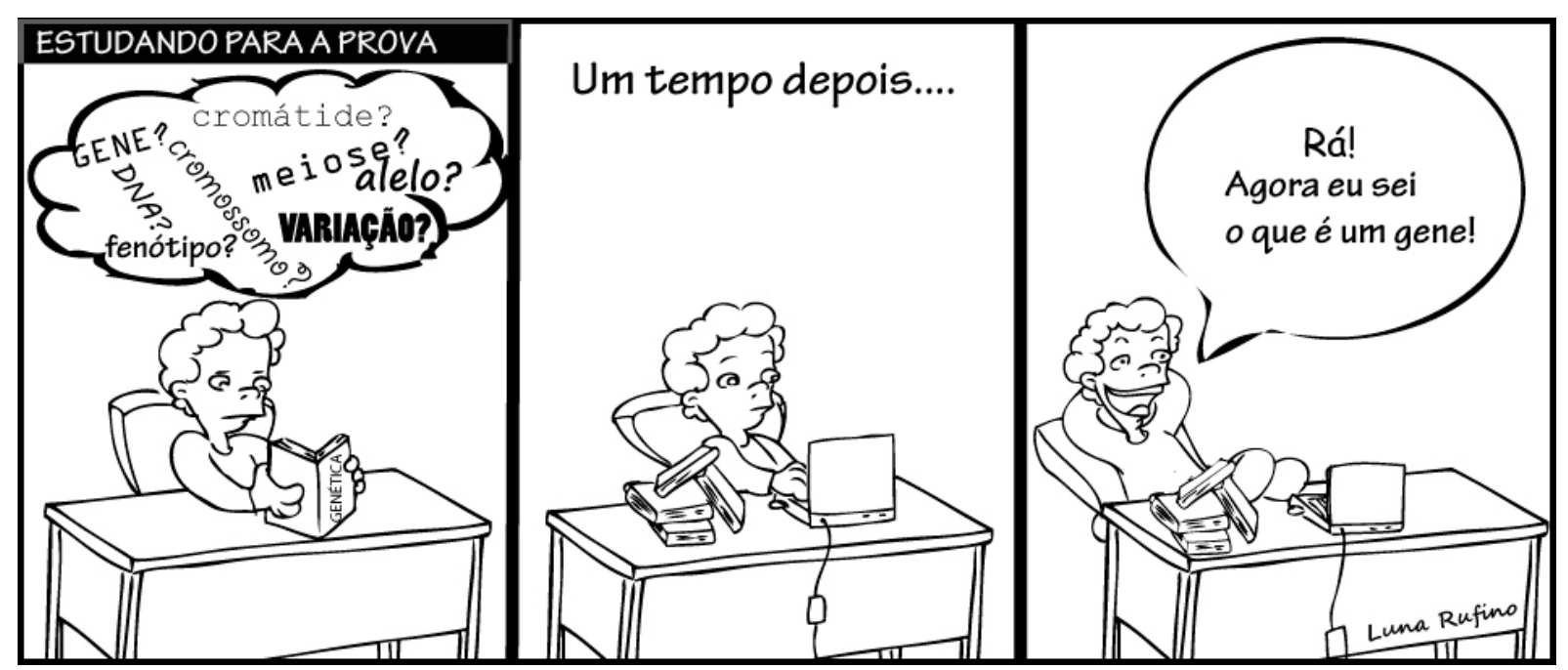

Figura 1 Estudando para a prova.

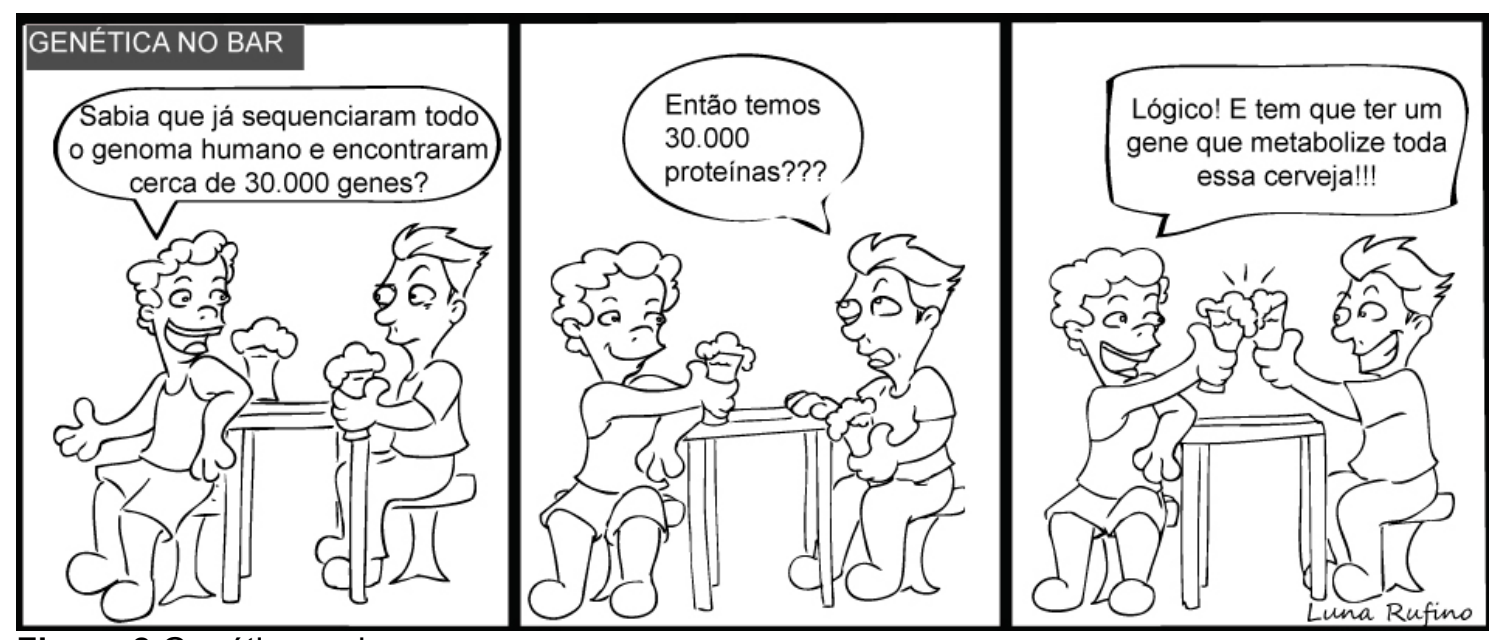

Figura 2 Genética no bar.



Figura 3 Palestra. 


\section{Anexo 4 - Artigo publicado na Revista Electrónica de Enseñanza de las Ciências, Vol extra, P. 2695-2700, 2013.}

\section{Tirinhas no ensino de genética: potencial para avaliação dos conhecimentos prévios sobre os genes}

Pedreira, Mariana Marzullo; Resende, Tatiana dos Anjos; Oliveira, Silviene Fabiana de; Klautau-Guimarães, Maria de Nazaré.

Laboratório de Genética Humana. Departamento de Genética e Morfologia, Instituto de Ciências Biológicas, Universidade de Brasília, Brasil.

\section{Resumo}

Diante dos avanços na genética, há uma discussão no ensino acerca do conceito de gene que afeta a construção do conhecimento deste conceito por parte dos estudantes. Utilizando como estratégia de avaliação tirinhas confeccionada para este fim, foram identificados os conhecimentos prévios sobre o conceito, estrutura e função de gene dos estudantes que cursam a disciplina de genética de dois cursos da Universidade de Brasília. Foi observada diferença dos conhecimentos prévios sobre o tema abordado entre os estudantes demonstrando a dificuldade de organização dos conhecimentos adquiridos. A utilização desse material fornece parâmetros para uma melhor orientação ao professor em disciplinas de graduação. Estratégias devem ser incluídas de maneira contextualizada para permitir uma visão mais abrangente ao estudante.

\section{Palavras chave:}

Conceito de gene, Ensino de Genética, Tirinhas, Conhecimentos Prévios.

\section{Objetivos}

Este trabalho tem como objetivo avaliar o conhecimento prévio de estudantes de graduação sobre o conceito, estrutura e função de gene antes de cursarem a disciplina "Genética", utilizando como recurso didático tirinhas especialmente desenvolvidas para estabelecer conexões por incentivo da estratégia e não por apresentar o conteúdo pronto.

\section{Marco Teórico}

O conceito original de gene como unidade indivisível da herança mendeliana, introduzido por Wilhelm L Johannsen em 1909, foi um dos marcos da história da ciência no século XX. Com o avanço do conhecimento do material genético, esse conceito evoluiu e atualmente o mais utilizado no ensino médio e superior é o conceito molecular clássico de gene: uma sequência de DNA responsável pela produção de uma molécula de RNA ou de um polipeptídio que desempenha uma função específica. Nesse conceito, observa-se uma relação de 1:1:1 entre genes, produtos gênicos e função gênica, que perpassa uma noção de unidade (El-Hani, 2007).

Com o aprofundamento nos conhecimentos sobre estrutura e funcionamento dos genomas, o conceito de gene passou a ser muito contestado, e se instalou uma crise diretamente relacionada ao modo de 
compreensão do mesmo pela comunidade científica levantando a necessidade de uma revisão (El-Hani 2007).

A dificuldade na compreensão do conceito básico é observada por parte de todos os atores no processo de ensino-aprendizagem da genética. Devido a esse impasse, equívocos com relação ao conceito de gene foram constatados em livros didáticos do ensino médio, ensino superior e em revistas de divulgação científica (Santos e El-Hani, 2009; Goldbach e El-Hani, 2008; Pitombo et al., 2008 e 2007).

Banet y Ayuso (2003) e Mbajiorgu et al (2007) relatam os principais problemas de compreensão de conceitos básicos da genética pelos estudantes do ensino médio. O conceito de gene é explicado pelos estudantes por concepções alternativas dificultando a construção do conhecimento científico, fazendo-se necessário identificá-las para o desenvolvimento de metodologias de ensino mais efetivas (Griffiths \& MayerSmith, 2000; Lewis, 2004).

Adicionalmente a crise do conceito de gene, a genética é uma disciplina teórica, abstrata, de difícil entendimento e visualização. Nesse sentido, foram desenvolvidas tirinhas que visam incentivar uma maior expressão e liberdade de opinião por parte dos estudantes. Dessa forma, este recurso didático foi utilizado para identificar os conhecimentos prévios dos estudantes a respeito do conceito de gene.

\section{Metodologia}

Procurando abordar de forma lúdica o conceito de gene, sua estrutura e função nos organismos, foram desenvolvidas tirinhas acompanhadas de questionamento (dados não publicados). A tirinha Estudando para a prova (Figura 1a) busca dinamizar a forma de questionar o conceito de gene. Já a tirinha, Genética no bar (Figura 1b) prioriza o caráter argumentativo dos estudantes, enquanto questiona a relação "um gene: uma proteína". Por fim, a tirinha Palestra (Figura 1c) aborda a relação entre a estrutura física do gene e a sequência de aminoácidos de uma proteína.

As tirinhas foram aplicadas para estudantes de duas turmas da disciplina Genética na Universidade de Brasília - Ciências Biológicas $(n=61)$ e Enfermagem ( $n=62)$-, no primeiro dia de aula. Essa disciplina é ministrada para Enfermagem no primeiro semestre letivo e para Ciências Biológicas no quinto, sendo que estes últimos já cursaram a disciplina Biologia Molecular, onde o conceito de gene é discutido. Foram considerados os estudantes que estavam matriculados na disciplina e que concordaram em participar. Para a realização da atividade, recomendou-se que não houvesse conversa e consulta de materiais extras, além de não identificarem suas respostas, garantindo assim o anonimato. 
(a)

(b) diria?

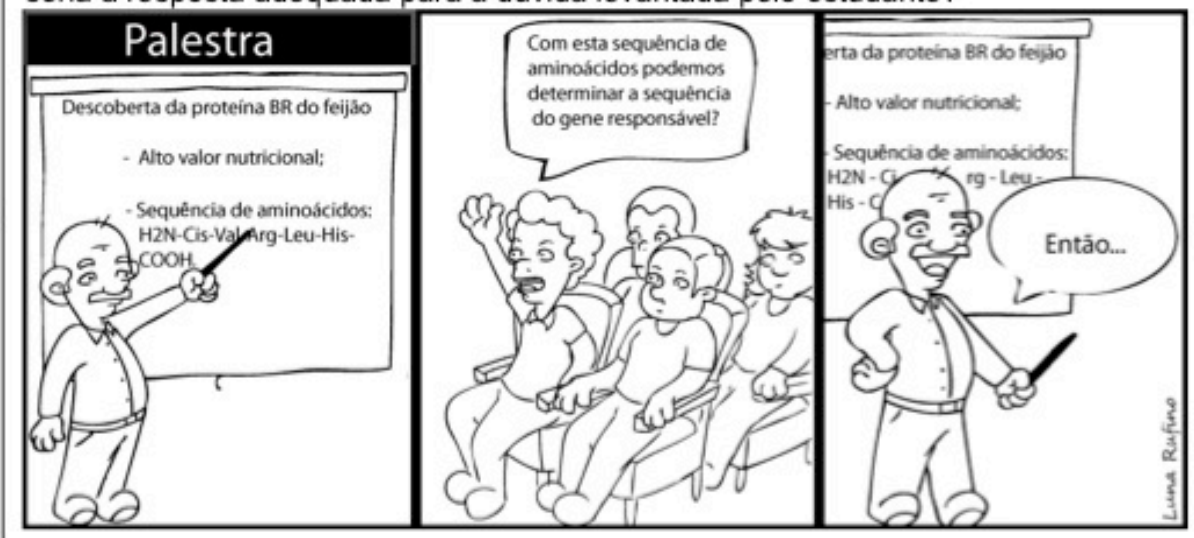

Em uma palestra sobre a descoberta sobre uma nova proteina em uma espécie de feijão, o pesquisador descreve a sequência de aminoácidos. Leia a tirinha. Qual seria a resposta adequada para a dúvida levantada pelo estudante?

Em uma mesa de bar surge um papo informal entre dois estudantes sobre os resultados do Projeto Genoma Humano. Lia a tirinha. Ao ouvir esse papo, o que

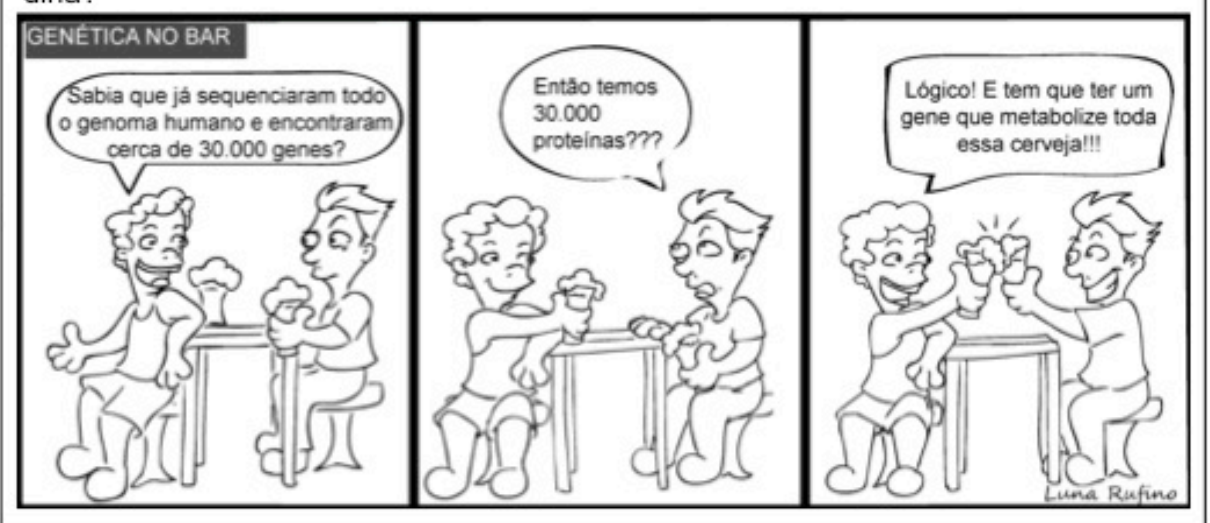

Tentando entender os principais conceitos da Genética, o estudante consulta diferentes fontes. Confiante em seu aprendizado, ele se sente preparado para novos desafios. Leia a tirinha. Como você definiria o conceito de gene?



Figura 1 (a) Palestra aborda a estrutura do gene e sua relação com a sequência de aminoácido. (b) Genética no bar prioriza o caráter argumentativo dos estudantes sobre a relação um gene : um proteína. (c) Estudando para a prova aborda o conceito de gene.

Foi desenvolvido um gabarito para análise das avaliações (Quadro 1). Este apresenta o que se espera como resposta de acordo com o conteúdo de um dos livros-textos mais utilizados no ensino médio brasileiro (Amabis e Martho, 2006). Os critérios de correções foram: (1) Resposta certa - 
conteúdo esperado; (2) Resposta errada - sem o conteúdo esperado; e (3) Abstenção - não responderam a avaliação.

Quadro 1 Gabarito para análise das avaliações das tirinhas.

\begin{tabular}{|c|c|}
\hline Tirinha & $\begin{array}{l}\text { Conhecimento esperado pelo aluno } \\
\text { recém ingressado no ensino superior }\end{array}$ \\
\hline Palestra & $\begin{array}{l}\text { É esperado, que o estudante tenha conhecimento } \\
\text { do (1) "Dogma central da Biologia Molecular", } \\
\text { onde há a correlação informacional entre DNA, } \\
\text { RNA e proteína ( } 1 \text { gene: } 1 \text { produto funcional); (2) } \\
\text { por meio do código genético. (3) Considerando } \\
\text { algumas variações, devido a redundância do } \\
\text { código genético, a sequência do gene } \\
\text { responsável não poderá ser inferida } \\
\text { completamente. }\end{array}$ \\
\hline Genética no bar & $\begin{array}{l}\text { Espera-se que os estudantes correlacionem o } \\
\text { "Dogma central da Biologia Molecular" e o } \\
\text { "Conceito molecular clássico de gene" (1) fazendo } \\
\text { a relação } 1 \text { gene: } 1 \text { função. Onde o gene será } \\
\text { visto como unidade de estrutura e função } \\
\text { (proteína, enzima, polipeptídeo ou RNA), não } \\
\text { havendo margem, portanto, para um relação } \\
\text { direta de } 1 \text { gene: } 1 \text { proteína. }\end{array}$ \\
\hline $\begin{array}{l}\text { Estudando para a } \\
\text { prova }\end{array}$ & $\begin{array}{l}\text { É esperado que os estudantes saibam o conceito } \\
\text { molecular clássico de gene. No conceito } \\
\text { molecular clássico, o gene é considerado (1) uma } \\
\text { sequência de DNA que (2) codifica um produto } \\
\text { funcional, que pode ser tanto um (3) polipeptídeo } \\
\text { quanto uma molécula de RNA, que por sua vez } \\
\text { (4) terá uma única função. }\end{array}$ \\
\hline
\end{tabular}

\section{Resultados}

Os resultados das análises das repostas dos estudantes aos questionamentos de cada tirinha estão apresentados na tabela 1, de acordo com os gabaritos no quadro 1 . Os dados apresentados revelam claramente uma discrepância entre os estudantes dos dois cursos analisados.

\section{Tirinha Palestra}

A porcentagem das abstenções dos estudantes do curso de Enfermagem foi de $17,7 \%$ e dos estudantes do curso de Ciências Biológicas foi de $4,9 \%$. Quanto às respostas classificadas como erradas observou-se que a maioria fez a relação direta da sequência de aminoácidos com a sequência de nucleotídeos do gene. Também detectou-se a presença de erros conceituais tais como: "os aminoácidos estão ligados às proteínas que os genes carregam" e "os aminoácidos fazem parte da composição do gene". As respostas classificadas como certas revelam que o conhecimento sobre o 
Dogma Central da Biologia Molecular e da redundância do código genético estão sedimentados nos estudantes de ambos os cursos. Porém, é no curso de Ciências Biológicas que se observa a maior porcentagem de acertos, acima de $60 \%$, com a presença de respostas que citam conhecimentos além dos esperados; tais como, processamento do RNA, éxons e íntrons.

\section{Tirinha Genética no Bar}

O questionamento da relação gene: proteína está claro para a maior parte dos estudantes de Ciências Biológicas e para cerca de $40 \%$ dos estudantes de Enfermagem, que essa relação não é de 1:1. Entretanto, constatou-se que alguns estudantes não apresentaram justificativas coerentes. Citações sobre o splicing alternativo foram detectadas em algumas respostas que superaram as expectativas deste trabalho. As respostas classificadas como erradas apresentaram confusão de conceitos nas justificativas para a relação errônea 1 gene: 1 proteína, predominantemente nos estudantes de Enfermagem.

Além disso, foi interessante notar que os estudantes criticaram a ideia de gene-centrismo presente na tirinha, com comentários como: "não é o gene que metaboliza a cerveja".

\section{Tirinha Estudando para a prova}

A porcentagem de abstenção desta tirinha foi a menor detectada, porém foi onde notou-se a maior porcentagem de respostas classificadas como erradas, com prevalência de ideias errôneas e confusas. Como, por exemplo, de que gene é sinônimo de "cromossomo", "é uma sequência de aminoácido", "é o princípio da divisão celular", dentre outros. É nesta análise que se detectou a maior aproximação porcentual entre os dois cursos, no entanto, as definições do conceito de gene são diferentes. Na Enfermagem o conceito predominante foi "gene mendeliano", enquanto nas Ciências Biológicas foi o "gene bioquímico-clássico.

O conhecimento do "conceito molecular clássico" do gene foi detectado para cerca de $34 \%$ dos estudantes de Ciências Biológicas e para apenas $11 \%$ dos estudantes de Enfermagem. Dentro deste conhecimento não há clareza nas respostas sobre quais produtos funcionais são originados, e quando citados houve predominância da "proteína" e omissão do "RNA". Os estudantes de Ciências Biológicas apresentaram respostas mais estruturadas e adequadas ao esperado, porém não houve uma resposta que tenha superado as expectativas.

Tabela 1 Resultados das tirinhas nos cursos de Ciências Biológicas $(n=61)$ e Enfermagem

\begin{tabular}{|c|c|c|c|}
\hline Tirinhas & Respostas & $\begin{array}{l}\text { Ciências } \\
\text { Biológicas } \\
(\%)\end{array}$ & $\begin{array}{l}\text { Enfermagem } \\
(\%)\end{array}$ \\
\hline \multirow{3}{*}{ Palestra } & Certo & 62,3 & 16,1 \\
\hline & Errado & 32,7 & 67,7 \\
\hline & Abstenções & 4,92 & 17,7 \\
\hline \multirow{2}{*}{ Genética no bar } & Certo & 90,1 & 43,5 \\
\hline & Errado & 6,5 & 45,1 \\
\hline
\end{tabular}




\begin{tabular}{l|l|l|l}
\hline & Abstenções & 8,2 & 14,5 \\
\hline \multirow{2}{*}{$\begin{array}{l}\text { Estudando para a a } \\
\text { prova }\end{array}$} & Certo & 34,4 & 11,2 \\
\cline { 2 - 4 } & Errado & 60,6 & 77,4 \\
\cline { 2 - 4 } & Abstenções & 4,9 & 12,9 \\
\hline
\end{tabular}

\section{Sequência das três tirinhas}

As avaliações das respostas da sequência completa das três tirinhas são apresentadas na tabela 2. A porcentagem de respostas certas das três tirinhas em conjunto foi de $27 \%$ nas Ciências Biológicas, enquanto que a porcentagem de respostas erradas das três tirinhas em conjunto foi de $46 \%$ na Enfermagem.

É importante ressaltar que na sequência em que só se detecta o acerto na tirinha Genética no Bar, o conhecimento do questionamento é comum aos dois cursos e predominante na Enfermagem. Na sequência onde há respostas erradas somente na tirinha Estudando para a Prova os estudantes de Ciências Biológicas se destacam.

Tabela 2 Visão geral dos cursos de Ciências Biológicas ( $n=61)$ e Enfermagem ( $\mathrm{n}=62)$.

\begin{tabular}{l|l|l|l|l}
\hline Palestra & $\begin{array}{l}\text { Genética } \\
\text { no bar }\end{array}$ & $\begin{array}{l}\text { Estudando } \\
\text { para a a } \\
\text { prova }\end{array}$ & $\begin{array}{l}\text { Ciências } \\
\text { Biológicas (\%) }\end{array}$ & $\begin{array}{l}\text { Enfermagem } \\
(\mathbf{\%})\end{array}$ \\
\hline Certo & Certo & Certo & 27,8 & 3,3 \\
\hline Certo & Certo & Errado & 32,7 & 4,8 \\
\hline Certo & Errado & Certo & 0,0 & 1,6 \\
\hline Certo & Errado & Errado & 1,6 & 6,4 \\
\hline Errado & Certo & Certo & 6,6 & 3,2 \\
\hline Errado & Certo & Errado & 21,3 & 32,2 \\
\hline Errado & Errado & Certo & 0,0 & 3,2 \\
\hline Errado & Errado & Errado & 9,8 & 46,7 \\
\hline
\end{tabular}

\section{Conclusão}

De acordo com o exposto no presente trabalho, há diferença de conhecimentos prévios sobre o conceito, estrutura e função do gene entre os estudantes de Ciências Biológicas e Enfermagem. Alguns fatores conhecidos contribuem para essa discrepância, como o fato de que os estudantes da Enfermagem são recém-ingressados na universidade enquanto os das Ciências Biológicas se encontram no quinto semestre. Dentro do período cursado pelos estudantes de Ciências Biológicas, a disciplina de "Biologia Molecular", onde o conceito de gene é discutido, foi obrigatória antes da "Genética".

Portanto, as respostas dos estudantes de Enfermagem refletem com maior fidelidade a compreensão dos conceitos a partir de informações obtidas no ensino médio. Esses resultados são consequências das dificuldades do ensino de genética tradicional centradas no excesso de vocabulário exclusivo e alto grau de abstração. Os diferentes níveis de pensamento, macro e micro, dificultam a visualização e compreensão dos estudantes quando se aborda o conceito de gene. O presente trabalho ressalta que este aspecto ultrapassa a barreira do ensino médio, valendo 
também para o ensino superior. Onde é demonstrado que ainda há dificuldades de organização dos conhecimentos adquiridos sobre conceito, estrutura e função do gene.

A utilização das tirinhas permitiu abordar o tema de uma forma diferente e interessante, incentivando a expressão e opinião dos estudantes sobre os seus conhecimentos prévios de acordo com os temas propostos. Portanto, a utilização desse material em sala de aula pode fornecer parâmetros que permitem uma melhor orientação ao professor em disciplinas de graduação, assim como sinalizar a necessidade de reformular a sequência dos conteúdos a serem abordados antes do início das aulas teóricas.

Para a organização do conhecimento do conceito, estrutura e função do gene no ensino superior se faz necessário incorporar novas estratégias didáticas. Tais estratégias devem incluir de maneira contextualizada os conhecimentos gerados pela genômica e a história da evolução do conceito de gene, isso permitirá uma visão mais abrangente ao estudante fugindo da ideia determinista da relação desse conceito e a herança biológica.

\section{Referências Bibliográficas}

Amabis, J.M. e Martho, G.R. (2006). Fundamentos da Biologia Moderna. São Paulo: Moderna.

Banet, E. E Ayuso, G.E. (2003). Teaching of biological inheritance and evolution of living beings in secondary school. International Journal of Science Education, 25(3), pp. 373-407.

El-Hani, C.N. e Mortimer, E.F. (2007). Multicultural education, pragmatism, and the goals of science teaching. Cult Stud of Sci Educ, 2, pp. 657-702.

Goldbach, T.; El-Hani, C.N. (2008). Entre Receitas, Programas e Códigos: Metáforas e Ideias Sobre Genes na Divulgação Científica e no Contexto Escolar. Revista de Educação em Ciência e Tecnologia, 1(1), pp. 153189.

Griffiths, A.J.F. y Mayer-Smith, J. (2000). Understanding Genetics Strategies for teachers and learners in universities and high schools. W.H. Freeman and Company: New York.

Lewis, J. y Kattmann, U. (2004). Traits, genes, particles and information: revisiting student's understandings of genetics. International Journal of Science Education, 26(2), pp. 195-206.

Mbajiorgu, N.M.; Ezechi, N.G.; Idoko, E.C. (2007). Addressing nonscientific presuppositions in genetics using a conceptual change strategy. Science \& Education, 91(3), pp. 419-438.

Pitombo, M.A.; Almeida, A.M.R.; El-Hani, C.N. (2007). Gene concepts in higher education cell \& molecular biology textbooks. In: Proceedings of the loste International Meeting on Critical Analysis Of School Science Textbook, pp. 855-864. University of Tunis. 
Pitombo, M.A.; Almeida, A.M.R. e El-Hani, C.N. (2008). Conceitos de gene e ideias sobre função gênica em livros didáticos de biologia celular e molecular do ensino superior. Contexto \& Educação, 77, pp. 81-110.

Santos, V.C. e El-Hani, C.N. (2009). Ideias sobre genes em livros didáticos de biologia do ensino médio publicados no Brasil. Revista Brasileira de Pesquisa em Educação em Ciências, 9(1), pp. a6. 